Prepared in cooperation with U.S. Department of Commerce, National Oceanic and Atmospheric Administration

\title{
Ground-Water Nutrient Flux to Coastal Waters and Numerical Simulation of Wastewater Injection at Kihei, Maui, Hawaii
}

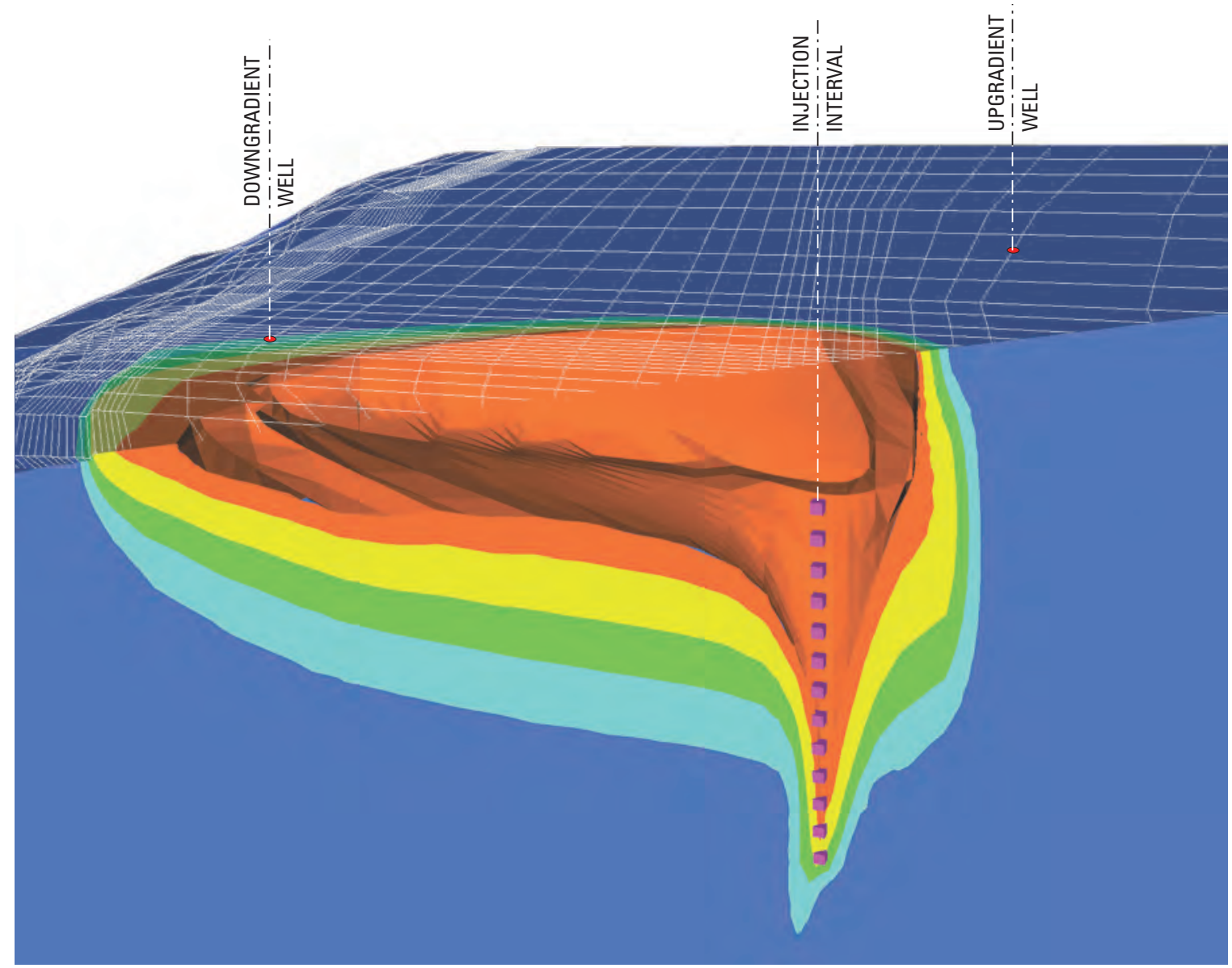

Scientific Investigations Report 2006-5283 
COVER

Cutaway block diagram of simulated wastewater injection plume at Kihei, Hawaii. View is to the northwest. The small cubes are injection nodes in the model. Injected effluent rises buoyantly, spreads out near the top of the aquifer, and flows to the coast; it also mixes with surrounding ground water, resulting in the gradation in effluent concentration shown by the colored bands. 


\section{Ground-Water Nutrient Flux to Coastal Waters and Numerical Simulation of Wastewater Injection at Kihei, Maui, Hawaii}

By Charles D. Hunt, Jr.

Prepared in cooperation with

U.S. Department of Commerce,

National Oceanic and Atmospheric Administration

Scientific Investigations Report 2006-5283 


\section{U.S. Department of the Interior DIRK KEMPTHORNE, Secretary}

\section{U.S. Geological Survey \\ Mark D. Myers, Director}

\section{U.S. Geological Survey, Reston, Virginia: 2007}

For product and ordering information:

World Wide Web: http://www.usgs.gov/pubprod

Telephone: 1-888-ASK-USGS

This report and any updates to it are available at http://pubs.usgs.gov/sir/2006/5283/

For more information on the USGS--the Federal source for science about the Earth, its natural and living resources, natural hazards, and the environment:

World Wide Web: http://www.usgs.gov

Telephone: 1-888-ASK-USGS

Any use of trade, product, or firm names is for descriptive purposes only and does not imply endorsement by the U.S. Government.

Although this report is in the public domain, permission must be secured from the individual copyright owners to reproduce any copyrighted materials contained within this report.

Suggested citation:

Hunt, C.D., Jr., 2007, Ground-Water Nutrient Flux to Coastal Waters and Numerical Simulation of Wastewater Injection at Kihei, Maui, Hawaii: U.S. Geological Survey Scientific Investigations Report 2006-5283, 69 p.

Manuscript approved for publication December 1, 2006 


\section{Executive Summary}

This report presents results of a U.S. Geological Survey (USGS) water sampling and modeling study at Kihei, on the island of Maui. The study was done in cooperation with the National Oceanic and Atmospheric Administration (NOAA), with funding supplied by the NOAA Coastal Oceans Program. Efforts were coordinated with those of marine scientists at the University of Hawaii in an overall program designed to assess factors contributing to blooms of macroalgae (seaweed). Excessive growth of macroalgae interferes with the coral-reef ecosystem, and seaweed accumulation and odor nuisance on Maui beaches cause \$20 million annual economic loss in removal expense and lost tourism. Nutrients are a possible contributing factor to the algae blooms, and this USGS study quantifies ground-water-borne nutrient fluxes on land as an integral part of the overall study design. Very few wells were sampled for this study and there is little field data to constrain model calibration, so nutrient fluxes and modeling results shown here are rough, first-order estimates.

The Kihei area of east Maui comprises an urbanized resort and residential strip shoreward of the main highway and an upland watershed that contains dryland forest, low-intensity cattle ranching, a few farms along an upper road, and wetter forest reserves farther upslope (fig. E1). Ground water flows from mountains to shore, carrying a background nutrient load from the upland watershed. As this water flows beneath the coastal urban strip, it picks up more nutrients from nonpoint sources (fertilizers, septic systems, sewer leaks) and from point-source wastewater injection at the main municipal treatment plant, for which a simulated effluent plume is shown.

\section{Ground-Water Nutrient Fluxes}

Background and wastewater nutrient fluxes were estimated in this study but the broader urban nonpoint flux was not (wells were sampled only near the injection wells and not farther up and down the coast). Despite advanced nutrient removal during wastewater treatment, injection still amounts to a large nutrient load for the region. However, the entire injected load does not necessarily reach coastal waters because nutrients are naturally attenuated in the aquifer. Attenuated wastewater nutrient flux, estimated from a single well within the effluent plume, was roughly $3^{1 / 2}$ times the background flux in recharge for both nitrogen and phosphorus (fig. E2). Background nitrogen flux at Kihei was 4 times as high as in west Maui—perhaps because Kihei is drier or has more nitrogen-fixing vegetation-but was one-half to one-third the flux from Hawaii Island golf courses.

\section{Size and Behavior of the Simulated Wastewater-Injection Plume}

A three-dimensional numerical ground-water model was used to simulate the regional freshwater lens and wastewater injection plume. Although effluent is injected deep into brackish and saline ground water, it rises as a buoyant plume and spreads out at the top of the aquifer (fig. E3), displacing other water flowing from uplands to shore. Effluent mixes with surrounding water, and plume discharge at the shore is roughly 60 percent effluent, according to the model. The simulated injection plume is roughly a mile wide at the coast and is centered on Kalama Park.

\section{Wastewater Tracers and Natural Attenuation of Nutrients}

Stable isotopes of nitrogen and boron were good nutrient and wastewater tracers, and imported tap water had distinctly different oxygen and hydrogen isotope signatures than local ground water, allowing imported water to be traced through the hydrologic cycle at Kihei. 


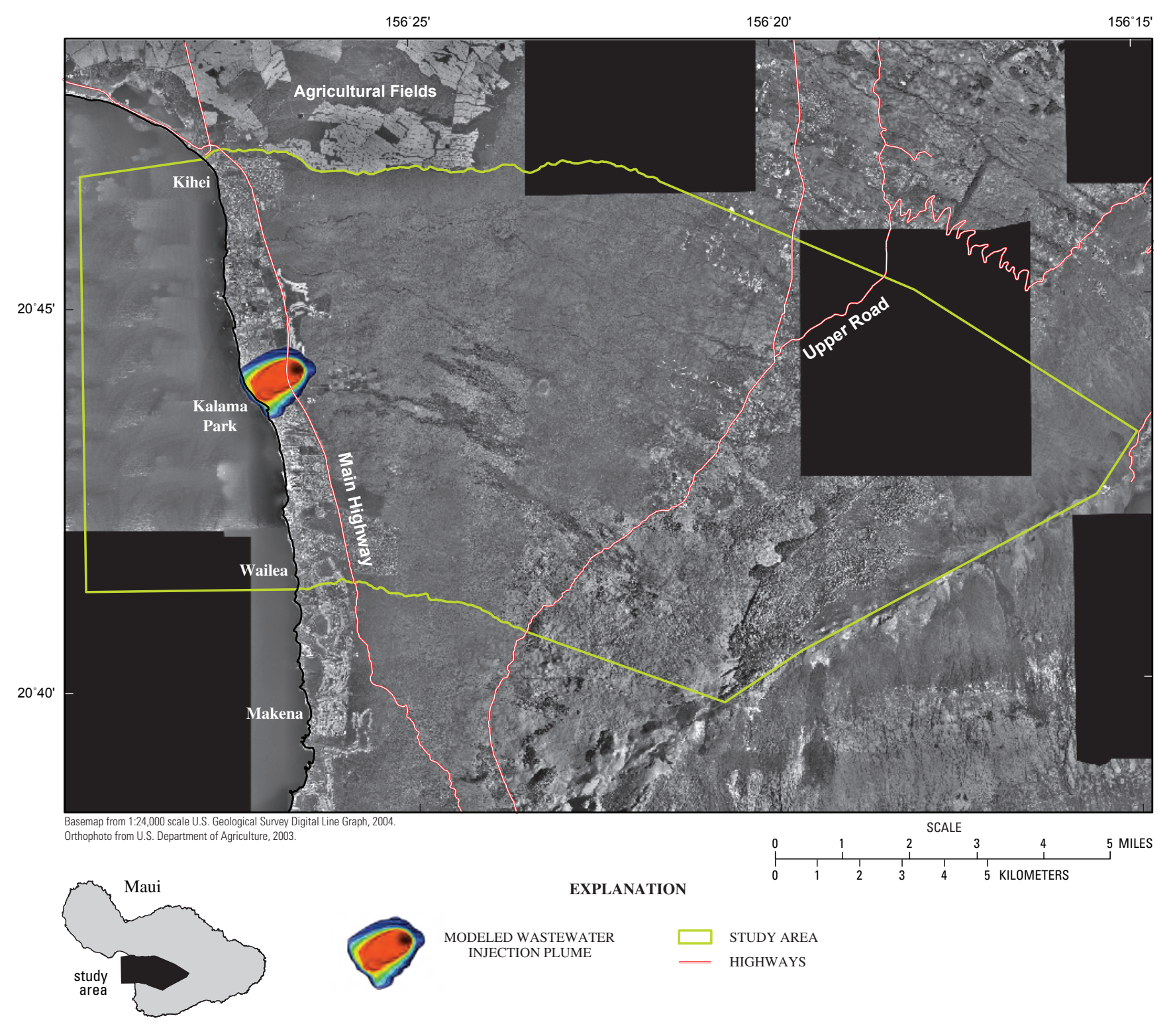

Figure E1. Aerial photomosaic showing the Kihei study area and injected wastewater effluent plume as estimated by numerical modeling, Kihei, Hawaii. The effluent plume is roughly a mile long and a mile wide $(0.93 \mathrm{mi}$, or $1.5 \mathrm{~km})$ and flows beneath the urban strip seaward of the main highway. Colors represent effluent concentration, from 100 percent effluent at the plume core to 5 percent effluent at the outer plume margin. The area inland of the highway is mostly dryland forest, with a few farms and rural homesteads along an upper road at 3,000 feet elevation. 


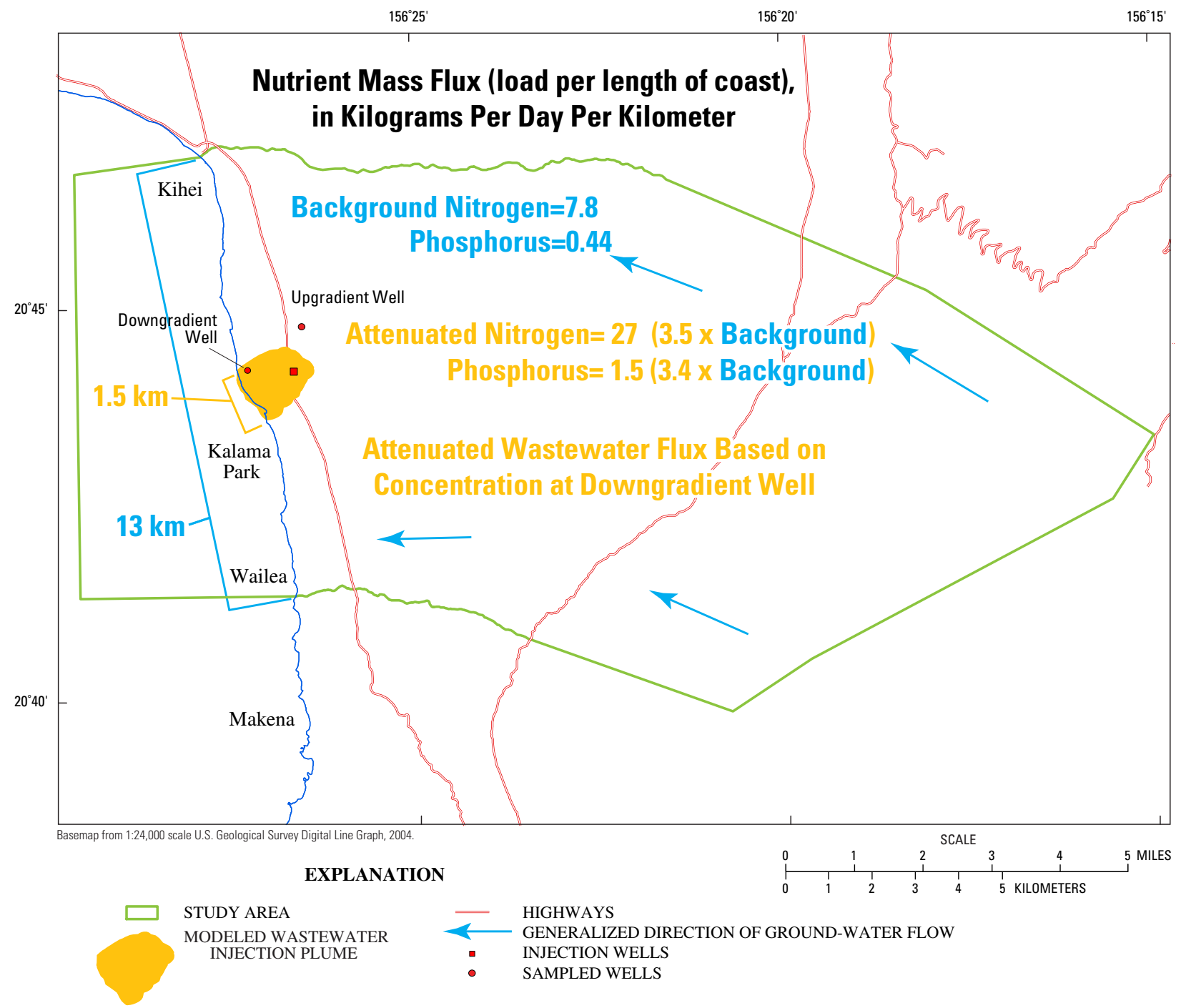

Figure E2. Map showing ground-water nutrient fluxes, Kihei, Hawaii. Blue lettering denotes regional fluxes, orange denotes injected fluxes. Background flux is the mass load of nitrogen and phosphorus in regional ground-water flow (blue arrows), estimated from concentrations at an upgradient well and divided by the 13-km coastline of the study area. Attenuated wastewater flux is the injected nitrogen and phosphorus load after natural attenuation in the aquifer, estimated from concentrations at a downgradient well in the effluent plume and divided by the $1.5-\mathrm{km}$ plume width. The attenuated wastewater flux is roughly $3 \frac{1}{2}$ times the background flux. 


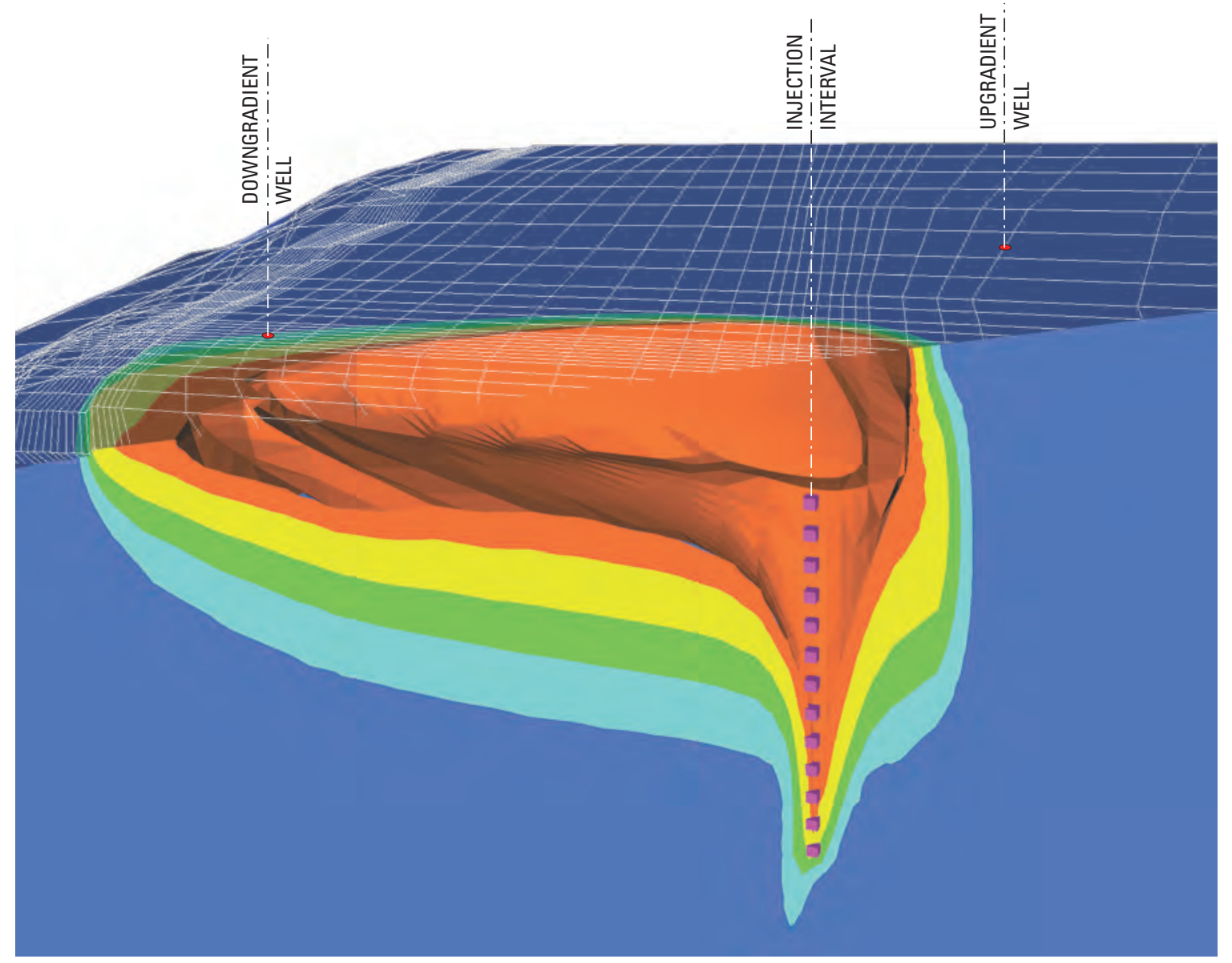

VERTICAL EXAGGERATION 20X

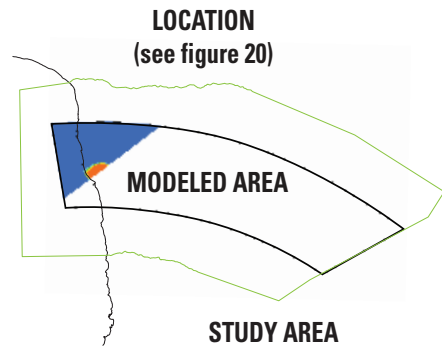

EFFLUENT-TRACER CONCENTRATION, IN PERCENT EFFLUENT

Figure E3. Cutaway block diagram showing the modeled injection plume, Kihei, Hawaii. View is to the northwest. The injection plume is visualized as effluent-tracer concentration, and the core of the plume is revealed by omitting concentrations greater than 90 percent. The small cubes are fluid-source nodes in the model that correspond to the open interval of the injection well. Injected effluent rises buoyantly, spreads out near the top of the aquifer, and flows to the coast; it also mixes with surrounding ground water, resulting in the gradation in effluent concentration shown. 
Nitrogen isotopes confirmed active denitrification in the wastewater effluent plume, and phosphorus also was substantially attenuated, although the processes responsible are less apparent.

\section{Study Limitations and Remaining Questions}

Principal limitations in this study were that only a few wells were sampled and that data for model calibration were sparse or unavailable, limiting the certainty of nutrient-flux estimates and modeling results. Furthermore, the urban nonpoint nutrient load was not quantified although this could be done by sampling more wells up and down the coast. In the urban area, fertilizer nutrients might be distinguishable from wastewater or septic sources using isotopic tracers identified in this study. Remaining questions about the effluent plume (exactly where and how far offshore it discharges) would perhaps be best answered by field sampling programs, such as pore-water sampling and nearshore trolling with water-quality instruments. Natural attenuation of nutrients was apparent, and the processes responsible may merit further attention given their importance in reducing nutrient loading to nearshore waters. Targeted monitor wells within the effluent plume would provide a means of confirming attenuation processes and identifying any further nutrient attenuation taking place between the shore and the one well sampled in this study that lay within the plume. 


\section{Contents}

Executive Summary .....................................................................................................................ii

Ground-Water Nutrient Fluxes ........................................................................................ii

Size and Behavior of the Simulated Wastewater-Injection Plume .......................................iii

Wastewater Tracers and Natural Attenuation of Nutrients ....................................................iii

Study Limitations and Remaining Questions ........................................................................vii

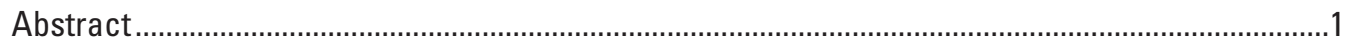

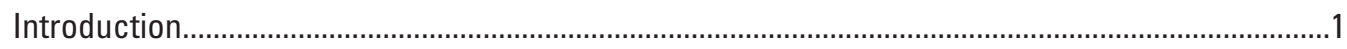

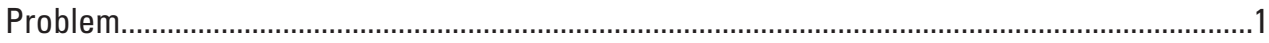

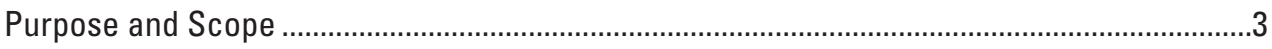

Objectives and Approach .........................................................................................................

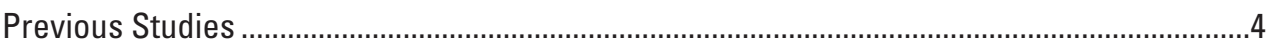

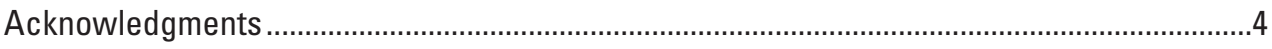

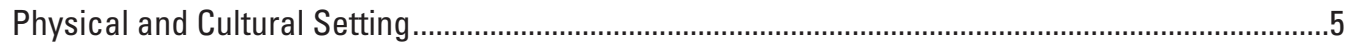

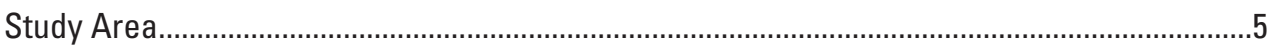

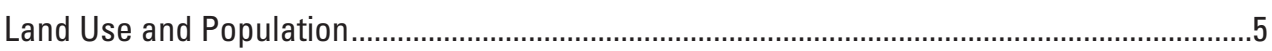

Topography, Drainage, and Climate.................................................................................

Wastewater Reclamation, Reuse, and Disposal ................................................................

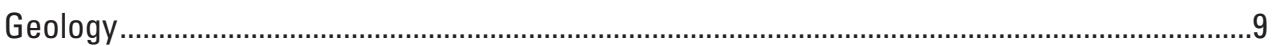

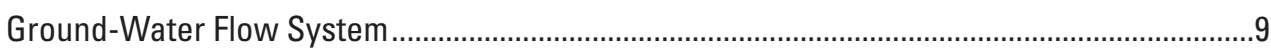

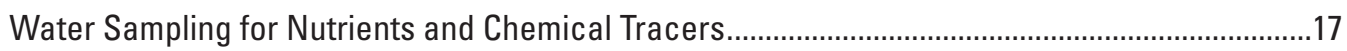

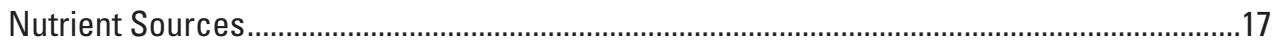

Water-Chemistry Sampling ...............................................................................................19

Pharmaceuticals and Organic Wastewater Compounds......................................................19

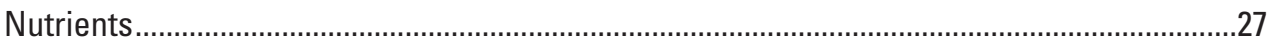

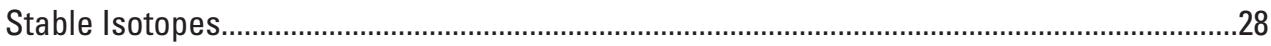

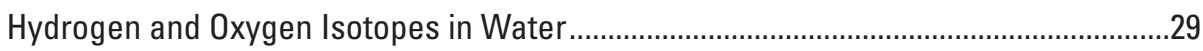

Nitrogen and Oxygen Isotopes in Dissolved Nitrate........................................................30

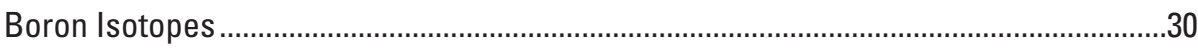

Water-Type Classification Using Nutrient and Stable-Isotope Signatures..............................31

Limitations of the Water-Chemistry Sampling.....................................................................33

Terrestrial Ground-Water and Nutrient Fluxes ...................................................................

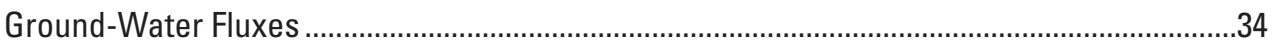

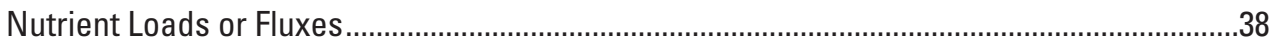

Comparison of Kihei Nutrient Fluxes with Other Areas in Hawaii ...........................................39

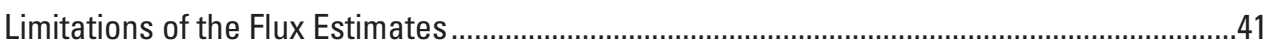

Simulation of Regional Ground-Water Flow and Wastewater Injection .........................................41

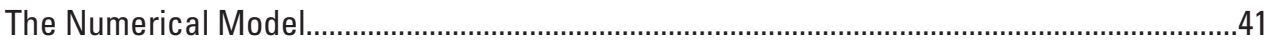

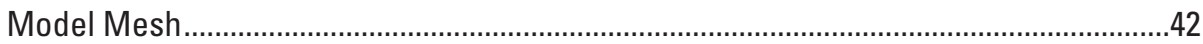

Model Boundary Conditions and Correspondence to Actual Hydrologic Boundaries ..42

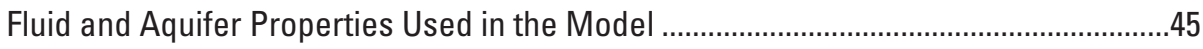

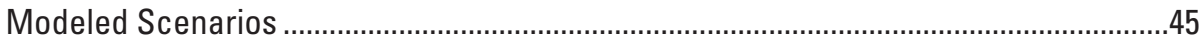

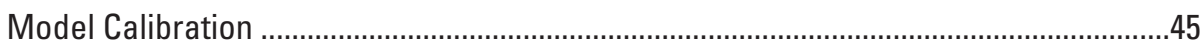


Simulation Results

Salinity Structure of the Freshwater-Saltwater Flow System ........................................49

Areal Patterns of Flow and Salinity Near the Shore ……………………………............49

Vertical Structure and Flow Dynamics of the Injection Plume ........................................50

Injection Plume Width and Dependence on Model Parameters.....................................55

Simulated Age of Ground Water ....................................................................................62

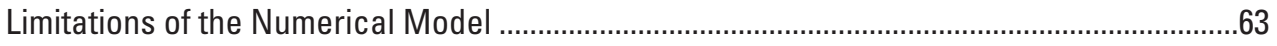

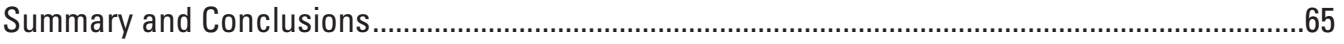

References

\section{Figures}

E1. Aerial photomosaic showing the Kihei study area and injected wastewater effluent plume as estimated by numerical modeling, Kihei, Hawaii ................................................iv

E2. Map showing ground-water nutrient fluxes, Kihei, Hawaii...............................................

E3. Cutaway block diagram showing the modeled injection plume, Kihei, Hawaii ................vi

1. Map showing the Kihei study area and shaded-relief topography of Maui, Hawaii ........2

2. Photograph of the invasive macroalgae species Hypnea musciformis on a beach at

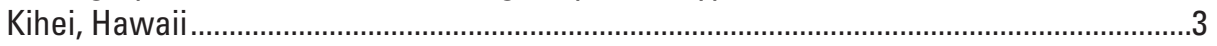

3. Aerial photomosaic showing the study area and lines of median annual rainfall,

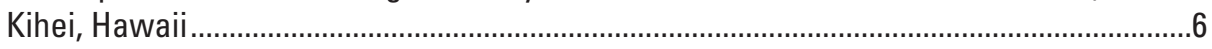

4. Map showing land-use districts, Kihei, Hawaii .............................................................

5. Map showing elevation contours, streams, and shaded-relief topography, Kihei, Hawaii

6. Aerial photomosaic showing Kihei Wastewater Reclamation Facility, reclaimed-water distribution system, and major reclaimed-water users, Kihei, Hawaii.....

7. Map showing unsewered lots, the Kihei reclaimed-water distribution system, and major reclaimed-water users, Kihei, Hawaii.....................................................................11

8. Map showing surface geology of the Kihei area, Hawaii.............................................12

9. Cross section A-A' showing geology and hydrology at Kihei, Hawaii ............................13

10. Map showing detailed surface geology of the coastal bench and selected information from subsurface drilling logs, Kihei, Hawaii ..................................................14

11. Map showing mean annual ground-water recharge, Kihei, Hawaii................................15

12. Map showing water levels in wells, Kihei, Hawaii.........................................................16

13. Map showing chloride concentrations in well water, Kihei, Hawaii ..............................18

14. Graph showing dissolved nitrogen and phosphorus concentrations in tap water, wastewater effluent, and untreated ground water, Kihei, Hawaii ...................................28

15. Graph showing oxygen and hydrogen stable-isotope compositions in tap water, wastewater effluent, and untreated ground water, Kihei, Hawaii ...................................29

16. Graph showing nitrogen and oxygen stable-isotope compositions of dissolved nitrate in tap water, wastewater effluent, and untreated ground water, Kihei, Hawaii.

17. Graph showing nitrate source classification based on nitrogen and oxygen stable-isotope compositions in dissolved nitrate. 
18. Graph showing boron and nitrogen stable-isotope compositions in tap water, wastewater effluent, and untreated ground water, Kihei, Hawaii .....................................34

19. Maps showing estimated ground-water and nutrient fluxes, Kihei, Hawaii ....................36

20. Map showing the finite-element mesh for the three-dimensional ground-water model, Kihei, Hawaii...........................................................................................................43

21. Block diagram showing the model finite-element mesh, Kihei, Hawaii ...........................44

22. Block diagram showing model boundary conditions, Kihei, Hawaii..................................44

23. Block diagram showing modeled salinity for the natural recharge scenario, Kihei,

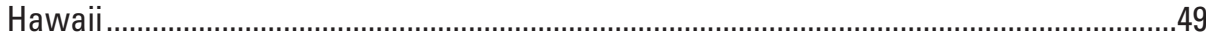

24. Map showing modeled salinity for the natural recharge scenario, Kihei, Hawaii ..........51

25. Map showing modeled salinity for the injection scenario, Kihei, Hawaii .........................52

26. Map showing modeled conservative effluent-tracer concentration for the injection scenario, Kihei, Hawaii ....

27. Cutaway block diagram showing modeled salinity for the injection scenario, Kihei, Hawaii

28. Cutaway block diagram showing modeled conservative effluent-tracer concentration for the injection scenario, Kihei, Hawaii....................................................56

29. Cross section showing modeled salinity and fluid velocity for the injection scenario, Kihei, Hawaii ...

30. Map showing modeled injection plume at an anisotropy ratio of 200:1, Kihei, Hawaii

31. Map showing modeled injection plume at a reduced anisotropy ratio of 20:1, Kihei, Hawaii

32. Cutaway block diagram showing modeled injection plume at an anisotropy ratio of 200:1, Kihei, Hawaii

33. Cutaway block diagram showing modeled injection plume at a reduced anisotropy ratio of 20:1, Kihei, Hawaii

34. Block diagram showing modeled age of ground water for the injection scenario, Kihei, Hawaii

35. Map showing modeled age of shallow ground water near the shore for the injection scenario, Kihei, Hawaii

\section{Tables}

1. Methods of water-quality analysis for samples collected at Kihei, Hawaii, November 15-17, 2004

2. Inorganic chemistry of tap water, wastewater effluent, and untreated ground water, Kihei, Hawaii, November 15-17, 2004

3. Pharmaceuticals in wastewater effluent and untreated ground water, Kihei, Hawaii, November 15-17, 2004

4. Organic wastewater compounds in wastewater effluent and untreated ground water, Kihei, Hawaii, November 15-17, 2004

5. Water-type classification derived from nutrient and stable-isotope compositions, Kihei, Hawaii, November 15-17, 2004. 
6. Estimated ground-water and nutrient fluxes, Kihei, Hawaii, November 2004 ..................35

7. Comparison of ground-water nutrient fluxes at Kihei, Maui, and elsewhere in Hawaii.

8. Model parameters and fluid flows for the three-dimensional ground-water model,

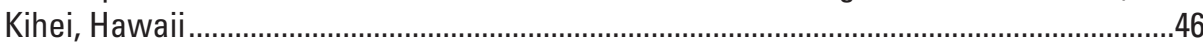

9. Model calibration targets and fitting errors for the three-dimensional ground-water model with injection, Kihei, Hawaii. 


\section{Conversion Factors}

\begin{tabular}{|c|c|c|}
\hline Multiply & By & To obtain \\
\hline \multicolumn{3}{|c|}{ Length } \\
\hline foot $(\mathrm{ft})$ & 0.3048 & meter $(\mathrm{m})$ \\
\hline mile (mi) & 1.609 & kilometer $(\mathrm{km})$ \\
\hline \multicolumn{3}{|c|}{ Area } \\
\hline acre & 0.004047 & square kilometer $\left(\mathrm{km}^{2}\right)$ \\
\hline square mile $\left(\mathrm{mi}^{2}\right)$ & 2.590 & square kilometer $\left(\mathrm{km}^{2}\right)$ \\
\hline \multicolumn{3}{|c|}{ Volume } \\
\hline million gallons (Mgal) & 3,785 & cubic meter $\left(\mathrm{m}^{3}\right)$ \\
\hline \multicolumn{3}{|c|}{ Flow rate } \\
\hline gallon per day (gal/d) & 0.003785 & cubic meter per day $\left(\mathrm{m}^{3} / \mathrm{d}\right)$ \\
\hline million gallons per day (Mgal/d) & 0.04381 & cubic meter per second $\left(\mathrm{m}^{3} / \mathrm{s}\right)$ \\
\hline inch per year (in/yr) & 25.4 & millimeter per year $(\mathrm{mm} / \mathrm{yr})$ \\
\hline \multicolumn{3}{|c|}{ Mass } \\
\hline pound, avoirdupois (lb) & 0.4536 & kilogram (kg) \\
\hline ton, short $(2,000 \mathrm{lb})$ & 0.9072 & megagram $(\mathrm{Mg})$ \\
\hline \multicolumn{3}{|c|}{ Pressure } \\
\hline atmosphere, standard (atm) & 101.3 & kilopascal $(\mathrm{kPa})$ \\
\hline bar & 100 & kilopascal $(\mathrm{kPa})$ \\
\hline pound per square inch $\left(\mathrm{lb} / \mathrm{in}^{2}\right)$ & 6.895 & kilopascal $(\mathrm{kPa})$ \\
\hline \multicolumn{3}{|c|}{ Hydraulic conductivity } \\
\hline foot per day (ft/d) & 0.3048 & meter per day $(\mathrm{m} / \mathrm{d})$ \\
\hline \multicolumn{3}{|c|}{ Hydraulic gradient } \\
\hline foot per mile $(\mathrm{ft} / \mathrm{mi})$ & 0.1894 & meter per kilometer $(\mathrm{m} / \mathrm{km})$ \\
\hline \multicolumn{3}{|c|}{ Transmissivity* } \\
\hline foot squared per day $\left(\mathrm{ft}^{2} / \mathrm{d}\right)$ & 0.09290 & meter squared per day $\left(\mathrm{m}^{2} / \mathrm{d}\right)$ \\
\hline \multicolumn{3}{|c|}{ Application rate } \\
\hline $\begin{array}{l}\text { pounds per acre per year } \\
\text { [(lb/acre }) / \mathrm{yr}]\end{array}$ & 1.121 & $\begin{array}{l}\text { kilograms per hectare per year } \\
{[(\mathrm{kg} / \mathrm{ha}) / \mathrm{yr}]}\end{array}$ \\
\hline \multicolumn{3}{|c|}{ Leakance } \\
\hline foot per day per foot $[(\mathrm{ft} / \mathrm{d}) / \mathrm{ft}]$ & 1 & meter per day per meter \\
\hline
\end{tabular}

Temperature in degrees Celsius $\left({ }^{\circ} \mathrm{C}\right)$ may be converted to degrees Fahrenheit $\left({ }^{\circ} \mathrm{F}\right)$ as follows:

${ }^{\circ} \mathrm{F}=\left(1.8 x^{\circ} \mathrm{C}\right)+32$

Temperature in degrees Fahrenheit $\left({ }^{\circ} \mathrm{F}\right)$ may be converted to degrees Celsius $\left({ }^{\circ} \mathrm{C}\right)$ as follows:

${ }^{\circ} \mathrm{C}=\left({ }^{\circ} \mathrm{F}-32\right) / 1.8$

Vertical coordinate information is referenced to mean sea level (msl).

Horizontal coordinate information is referenced to the North American Datum of 1983 (NAD 83).

Altitude, as used in this report, refers to distance above the vertical datum.

Specific conductance is given in microsiemens per centimeter at 25 degrees Celsius $(\mu \mathrm{S} / \mathrm{cm}$ at $\left.25^{\circ} \mathrm{C}\right)$.

Concentrations of chemical constituents in water are given either in milligrams per liter (mg/L) or micrograms per liter $(\mu \mathrm{g} / \mathrm{L})$. 



\title{
Ground-Water Nutrient Flux to Coastal Waters and Numerical Simulation of Wastewater Injection at Kihei, Maui, Hawaii
}

\author{
By Charles D. Hunt, Jr.
}

\section{Abstract}

Water sampling and numerical modeling were used to estimate ground-water nutrient fluxes in the Kihei area of Maui, where growth of macroalgae (seaweed) on coral reefs raises ecologic concerns and accumulation on beaches has caused odor and removal problems. Fluxes and model results are highly approximate, first-order estimates because very few wells were sampled and there are few field data to constrain model calibration. Ground-water recharge was estimated to be 22.6 Mgal/d (million gallons per day) within a 73-square-mile area having a coastline length of 8 miles or $13 \mathrm{~km}$ (kilometers). Nearly all of the recharge discharges at the coast because ground-water withdrawals are small. Another $3.0 \mathrm{Mgal} / \mathrm{d}$ of tertiary-treated wastewater effluent is injected into the regional aquifer at a County treatment plant midway along the coast and about a mile from shore. The injection plume is 0.93 miles wide $(1.5 \mathrm{~km})$ at the shore, as estimated from a three-dimensional numerical ground-water model. Wastewater injected beneath the brackish ground-water lens rises buoyantly and spreads out at the top of the lens, diverting and mixing with ambient ground water. Ground water discharging from the core of the injection plume is less than 5 years old and is about 60 percent effluent at the shore, according to the model. Dissolved nitrogen and phosphorus concentrations in treated effluent were 7.33 and 1.72 milligrams per liter, roughly 6 and 26 times background concentrations at an upgradient well. Background nitrogen and phosphorus fluxes carried by ground water are 7.7 and $0.44 \mathrm{~kg} / \mathrm{d}-\mathrm{km}$ (kilograms per day per kilometer of coast). Injected wastewater fluxes distributed across the plume width are 55 and $13 \mathrm{~kg} / \mathrm{d}-\mathrm{km}$ nitrogen and phosphorus, roughly 7 and 30 times background flux. However, not all of the injected load reaches coastal waters because nutrients are naturally attenuated in the oxygen-depleted effluent plume. Water from a downgradient well reflects this attenuation and provides a more conservative estimate of injection flux approaching the shore: 27 and $1.5 \mathrm{~kg} / \mathrm{d}-\mathrm{km}$ nitrogen and phosphorus, roughly one-half and one-ninth the injection-source estimates, and 3.5 and 3.4 times background flux. Effluent has $\delta^{18} \mathrm{O}$ and $\delta^{2} \mathrm{H}$ stable-isotope signatures that are distinct from local ground water, as well as $\delta^{15} \mathrm{~N}$ and $\delta^{11} \mathrm{~B}$ signatures diagnostic of domestic waste and laundry detergents, respectively. Pharmaceuticals and organic wastewater compounds also were present in effluent and the downgradient well. These isotopes and chemicals served as wastewater tracers in Kihei ground water and may be useful tracers in nearshore marine waters and aquifers elsewhere in Hawaii.

\section{Introduction}

The Kihei area comprises a strip of resort and residential development along the west coast of east Maui, Hawaii (fig. 1). Hotels and resort condominiums line much of the shore, and the economy of the area is largely tourism-based, with visitors coming to enjoy the warm climate, sandy beaches, and ocean recreation. The area is one of two major resort developments on the island, the other being the Lahaina area in west Maui.

\section{Problem}

The Kihei coast has been designated an impaired water body or "Water Quality Limited Segment" for exceeding nitrogen water-quality criteria (State of Hawaii, 1996). Suspected contributing sources of nitrogen are stormwater runoff, as well as agricultural and natural ground-water flow. A recurring problem in recent years at Kihei and elsewhere in Hawaii is excessive growth of macroalgae (seaweed) in nearshore coastal waters. Periodic algal blooms bring potentially serious ecological consequences (overgrowth and smothering of corals and other desirable reef species), aesthetic nuisance (seaweed washes onto beaches, decomposes, and creates odors, fig. 2), and economic loss (estimated at \$20 million annually in seaweed removal expense and lost tourism revenue on Maui). Both native and alien species of algae are of concern, and the occurrence and causes of the algal blooms are under study (University of Hawaii, undated). Potential contributing factors to macroalgal blooms include introduction of alien species of algae, population reductions in algal grazers, such as fish and urchins, and addition of nutrients from terrestrial sources (fertilizers, wastewater) or marine sources (sediment resuspension, upwelling, gravity waves). Terrestrial ground-water sources of nutrients are the subject of this report. 


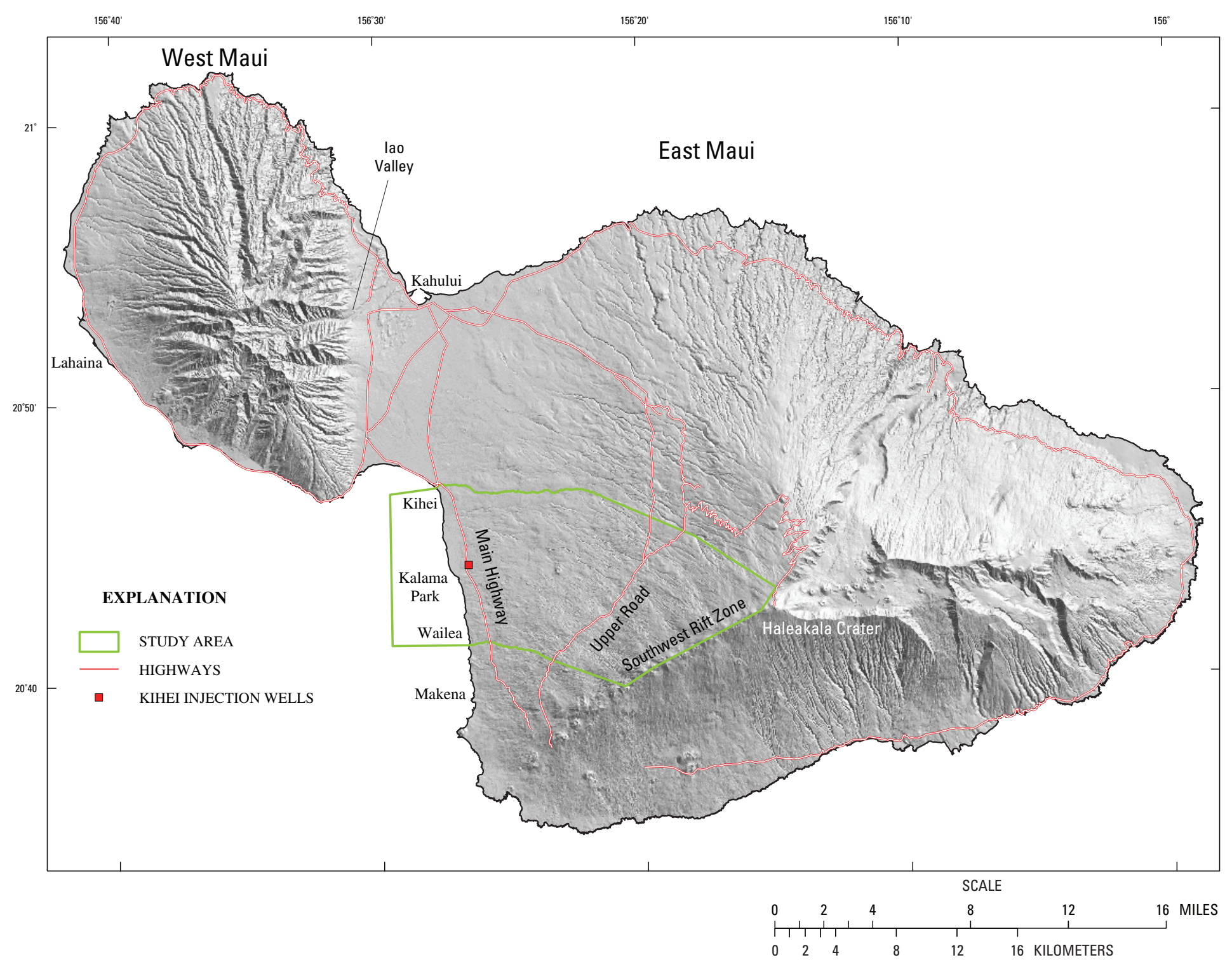

Figure 1. Map showing the Kihei study area and shaded-relief topography of Maui, Hawaii. The study area lies on the southwest flank of East Maui Volcano. Municipal freshwater is imported by pipeline from lao Valley to the north. 


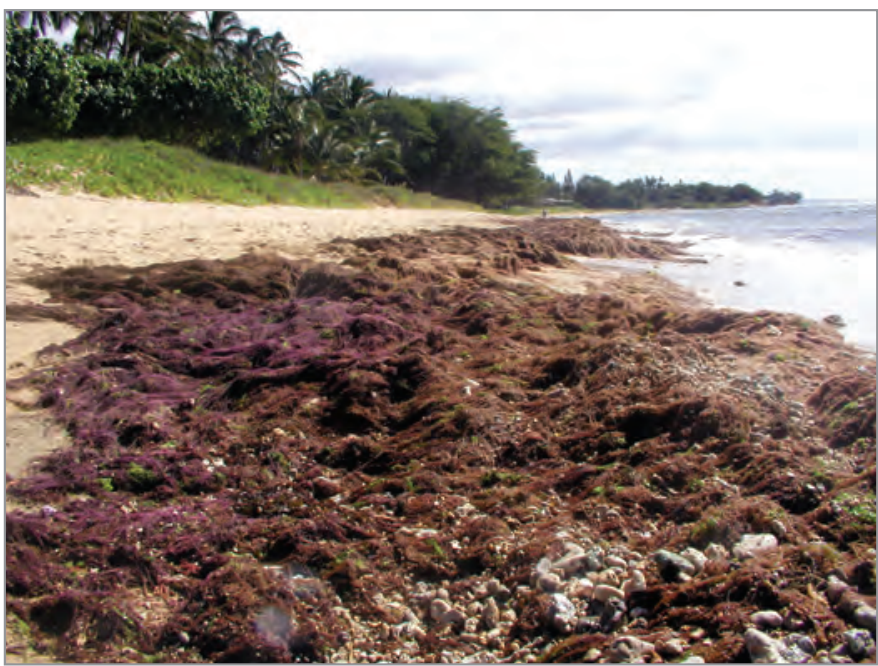

Figure 2. Photograph of the invasive macroalgae species Hypnea musciformis on a beach at Kihei, Hawaii. Large accumulations of seaweed cause visual and odor nuisances and substantial expenditures for removal. (Photograph by Jennifer Smith, University of Hawaii.)

\section{Purpose and Scope}

The purpose of this report is to convey results of landbased investigations of ground-water and nutrient fluxes from mountain to shore in the Kihei area of Maui. The study was funded by the National Oceanic and Atmospheric Administration (NOAA), National Ocean Service (NOS), under NOS Agreement Code MOA-2003-36/933, entitled "ECOHAB: Nutrient Input from Groundwater to the Nearshore Ocean Environment of West Maui, HI.” Efforts reported here include ground-water sampling for nutrients, identification of useful nutrient and wastewater tracers, estimation of ground-water nutrient loads, and three-dimensional numerical simulation of a wastewater injection plume at Maui County disposal wells.

This report does not address causes of algal blooms or the role of nutrients in the blooms. However, the study reported here is part of a larger program that does address these issues, entitled "Nuisance Macroalgal Blooms in Coastal Maui: Assessment and Integration of Physical Factors and Biological Processes." This project also was funded by NOAA and included coinvestigators from the University of Hawaii, the Hawaii Department of Health, the Hawaii Division of Aquatic Resources, and the U.S. Geological Survey (USGS). The overall project addressed the marine environment by characterizing chemical, biologic, and ecologic aspects of algal blooms in nearshore marine waters.

\section{Objectives and Approach}

Objectives of this study were to:

- Estimate the flux, or load, of nutrients carried to the shore by ground water;

- Provide regional knowledge of the location and concentration of nutrient-laden ground-water discharge to the coastal zone;

- Provide a linkage between nutrient fluxes on land (both natural and anthropogenic) and marine nutrient fluxes;

- Provide information that will contribute to the investigation of ocean-bottom pore-water chemistry, as well as to nutrient-based algal growth models.

As an approach to fulfilling the above objectives, the following tasks were carried out:

- Wastewater effluent and several wells were sampled for nutrients and other constituents, including various stable-isotope and organic wastewater tracers;

- Ground-water nutrient loads were estimated from sampled nutrient concentrations and ground-water flow rates (ground-water recharge and wastewater injection rate);

- A three-dimensional ground-water model was developed and used to simulate the regional freshwater lens and wastewater injection plume in the aquifer beneath the Kihei Wastewater Reclamation Facility.

The study originally was intended for the Lahaina area of west Maui and new monitor wells were proposed to intercept the injected wastewater plume between Maui County injection wells and the shore. Concerns with land availability for monitor wells caused the study to be relocated to Kihei, where continued drilling-permit delays required that existing wells be sampled in lieu of new monitor wells. Despite the relocation, objectives and approach remained largely the same as originally planned. One key difference, however, is that the Lahaina area is more intensely agricultural than the Kihei area. The Lahaina uplands were occupied for most of the $20^{\text {th }}$ century by plantation agriculture, whereas the Kihei uplands have been covered mainly in brush forest with some small-scale cattle ranching and diversified-crop farming. Plantation agriculture is known to add a large nutrient load to the hydrologic system from fertilizers, and potential changes in agricultural management practices that might have been evaluated in the Lahaina area are not relevant at Kihei. However, both areas have similar county wastewater reclamation facilities with injection disposal of effluent, and this remained a central focus of study at Kihei. 
Injection of treated, reclaimed wastewater effluent at the county injection wells is expected to form an injection plume within the aquifer, with injected effluent displacing other ground water that recharged farther inland and is flowing shoreward. The dimensions and shape of the plume are not known but can be estimated in several ways. The approach taken here was to model the ground-water flow system, assigning reasonable values for recharge, injection rate, and aquifer properties, and then examine simulation results. Plume modeling was supported by field sampling of ground water and analysis for diagnostic chemicals carried by wastewater (these chemicals serve as "passive" or "inherent" wastewater tracers, in contrast to an "introduced" tracer such as fluorescent dye). Water sampling was at wells on land only, whereas University of Hawaii researchers have collected water samples from nearshore marine waters, ocean-bottom pore waters, and seeps at the beach face.

\section{Previous Studies}

Nutrients and their potential role in marine macroalgal blooms were subjects of intensive study in the Lahaina area of west Maui in the mid-1990s (West Maui Watershed Management Project, 1996; West Maui Watershed Management Advisory Committee, 1997). Participants in this comprehensive effort included NOAA, USEPA, and various university researchers and private consultants. Several elements of the land-sea margin were studied, including surface-water runoff, ground-water flow, the marine water column and benthic communities, and substrate pore waters.

Land-based estimates of nutrient loads carried by terrestrial ground water at Lahaina were made by Soicher and Peterson (1996, 1997) and by Dollar and Andrews (1997). Principal sources of nutrients were sugarcane and pineapple agriculture, cesspools, resorts and golf courses, and municipal wastewater injection like that at Kihei. An introduced tracer test was attempted at county injection wells at Lahaina using rhodamine fluorescent dye, but results were largely inconclusive, with dye concentrations in nearby marine waters undetectable or barely detectable at the lower limit of instrument sensitivity (Tetra Tech, 1994).

Elsewhere, Dollar and Atkinson (1992) estimated groundwater nutrient fluxes at Waikoloa and Keauhou on the west coast of Hawaii Island. Both areas are resorts with golf courses that are irrigated with a combination of brackish ground water and treated wastewater, which constitutes one-third of total irrigation at Keauhou and one-tenth at Waikoloa. On Oahu Island, Garrison and others (2003) measured submarine ground-water discharge at Kahana Bay, using bottom seepage meters, and estimated nutrient loads from concentrations in the discharge. The inland area there was mostly forested, with a minor amount of small-plot agriculture and a beach-park septic system.
Injection-well disposal of wastewater was studied thoroughly in Hawaii in the 1970s. Various physical and numerical models were used to study injection processes at the University of Hawaii, a good example being the report by Heutmaker and others (1977). Burnham and others (1977) used a digital ground-water model to study wastewater injection and formation of a buoyant injection plume at Kahului, Maui.

The geology and hydrology of Maui were studied comprehensively by Stearns and Macdonald (1942), who also published an island-wide geologic map. Takasaki (1972) studied the water resources of central Maui and included discussions of ground-water levels and salinity in the Kihei area. Shade (1999) developed a digital water budget for east Maui, from which results for the Kihei area have been extracted and used in the present study. Scholl and others (2002) sampled atmospheric precipitation along several transects in east Maui and determined stable-isotope compositions defining a local "meteoric line."

\section{Acknowledgments}

The National Oceanic and Atmospheric Administration provided funding for this study through its Coastal Oceans Program. The County of Maui Department of Public Works and Environmental Management provided valuable assistance. Scott Rollins supplied detailed historical records of reclaimedwater and injection flows, as well as digital maps of the reclaimed-water distribution system. Steve Parabicoli provided water-quality specifications of the reclaimed water. Sampling assistance and access to records at the Kihei Wastewater Reclamation Facility were provided by Jerry Morgan (Operations Superintendent), Clarence Solomon, and Anita Fernandez. Rob Parsons (Maui County Environmental Coordinator) gave an overview of environmental issues in the Kihei area and helped coordinate permit applications for monitor wells.

Permission to sample wells and helpful logistical assistance were provided by Peter Maunsell at Maui Vista resort; Ray Skelton and John Maloney on behalf of Maui Research and Technology Park; and Jeffrey Kuwada and Ron Sturtz (individual property owners). Chien-Hwa Chen (USGS) assisted in sampling wells and effluent. Dave Sherrod (USGS) supplied a digital version of Stearns and Macdonald's (1942) geologic map that was used to create map illustrations.

Collaborators on the larger study of algal blooms offered valuable insights and marine-sampling results in joint meetings that helped focus this study and ensure coordination with theirs. I thank University of Hawaii researchers Celia Smith, Frank Sansone, Jennifer Smith, Iuri Herzfeld, Cindy Hunter, and Yu Umezawa; and also June Harrigan at Hawaii Department of Health and Robert Nishimoto at Hawaii Division of Aquatic Resources. Wendy Wiltse (U.S. Environmental Protection Agency) and Steve Dollar (University of Hawaii) provided publications from prior studies, as well as perspectives on nutrient issues in nearshore marine waters. 


\section{Physical and Cultural Setting}

The Kihei study area comprises 73 square miles of arid brushland, upland forest and small farms, and urban resort and residential areas along the coast. Ground-water recharge maintains a thin freshwater lens within an extensive aquifer of stratified volcanic lava flows. The freshwater lens is brackish within a mile of the shore and is not used as a source of drinking water. Instead, water for public supply is imported from a wetter area to the north. Municipal wastewater is reclaimed by tertiary treatment at a central plant; one-third of the treated effluent is distributed for reuse by landscape irrigation, and the remaining two-thirds are disposed in deep injection wells about a mile inland from the shore.

\section{Study Area}

The study area is located on the southwest flank of East Maui (Haleakala) Volcano (fig. 1) and encompasses 73 square miles of land area and 8 miles of coastline. The area was delineated with several purposes in mind:

- To encompass a large extent of the Kihei coast, including the Maui County wastewater injection wells and selected urban and resort lands to the north and south;

- To define an area for computing ground-water recharge, both to estimate nutrient mass loads and to assign prescribed flows in a numerical ground-water model; and

- To define the areal extent of the ground-water model, taking geohydrologic boundaries into account.

The inland boundary of the study area follows the southwest rift zone of East Maui Volcano (fig. 3). Eruptive cinder cones along the rift zone are visible in the aerial photo (also visible in fig. 1), and several late lava flows can be distinguished as well (they correspond to mapped flows in fig. 8). Also visible in fig. 3 are urban land along the coast shoreward of the main highway and a golf course just north of the County injection wells. The offshore study-area boundary is aligned roughly north-south about 2 miles off the coast. The north and south boundaries follow prominent streams near the coast, but were generalized to straight lines farther inland. The northern boundary separates scrub forest to the south from sugarcane fields to the north. The southern boundary includes the Maui Meadows residential subdivision (just inland from the main highway), but it excludes most of the Wailea resort and all of the Makena resort farther south, mainly to limit the size of the area under study.

\section{Land Use and Population}

Although most of the study area is zoned as agricultural (fig. 4), much of this land is covered with brush and trees and is unused or used for low-intensity ranching. Urban development along the coast comprises resort, residential, and commercial properties. Resort hotels and condominiums are concentrated near the shore, whereas residential housing extends inland about a mile to the main highway. One golf course lies within the study area just north of the county injection wells, and five more courses are located south of the study area at Wailea and Makena. A strip of rural farm and ranch homesteads lies along an upper road at about 2,000 feet elevation, where air temperatures are cooler than at the coast. Lands near the mountain summit are zoned as conservation and typically are fenced and protected forests that serve as managed watershed, biological habitat, and State and national parks.

The resident population in 2000 was 19,334 in the North Kihei, South Kihei, and Wailea census tracts that constitute the urban coastal strip within the study area and immediately to the south (State of Hawaii, 2004b). Including visitors, the total de facto population may be about 25,000 (a rough estimate obtained by multiplying the resident population by the totalto-resident ratio of 1.31 for all of Maui County).

\section{Topography, Drainage, and Climate}

The study area rises from sea level to almost 10,000 feet above sea level at its inland edge (fig. 5). This flank of Haleakala Volcano is relatively uneroded, owing to a dry climate and continual blanketing by young lava flows. Soils are thin compared to wetter parts of the island, and the land surface is rocky, particularly on younger lava flows. Several stream channels drain the area, but they are not deeply incised. Streamflow is highly intermittent; streams are dry most of the time and flow only during storms. A flat coastal plain extends about a half-mile inland from the shore in the northern half of the study area and is dotted with ponds and wetlands, where the water table intersects the low-lying land surface.

The southwest flank of the volcano has an arid climate because it lies in the rain shadow of the mountain, which intercepts persistent moist trade winds on its northeastern flank. Median annual rainfall (fig. 3) increases with elevation from less than about 15 inches at the coast to almost 50 inches at the inland extent of the study area (fig. 3; Giambelluca and others, 1986). A persistent band of cloud and fog formation about 5,000 feet above sea level also contributes to precipitation (Shade, 1999). 


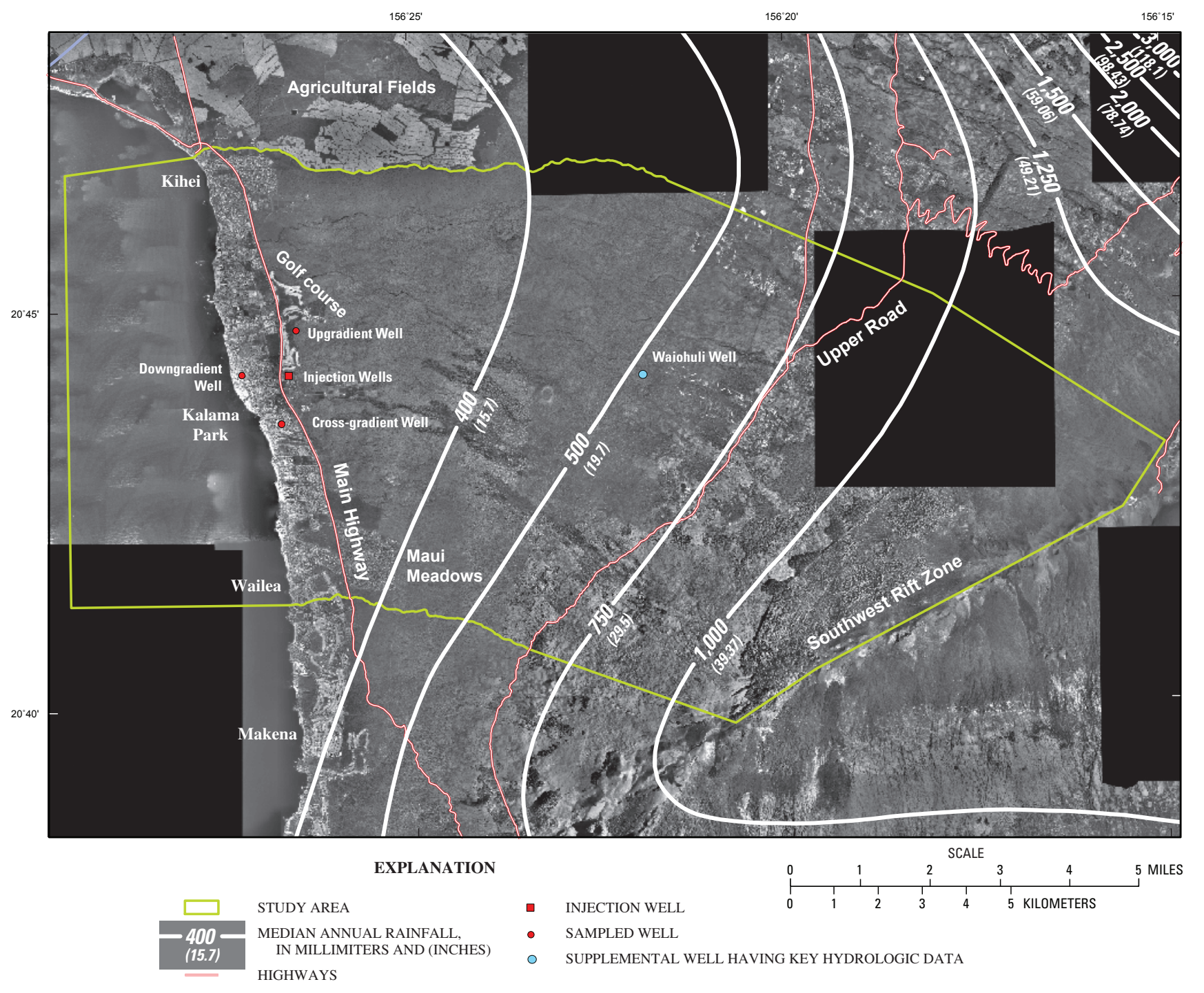

Figure 3. Aerial photomosaic showing the study area and lines of median annual rainfall, Kihei, Hawaii. Annual rainfall increases from less than $400 \mathrm{~mm}$ (15.7 in) along the coast to as much as $1,200 \mathrm{~mm}(47.24 \mathrm{in})$ in the forested uplands. Urban development is concentrated along the coast, although a notable exception is the large residential subdivision of Maui Meadows inland of the main highway. Sugarcane is cultivated outside the study area to the north. Three wells were sampled in the vicinity of the Maui County wastewater injection wells, and data from the Waiohuli well were used for ground-water model calibration. (Digital orthophotomosaic by U.S. Department of Agriculture.) 


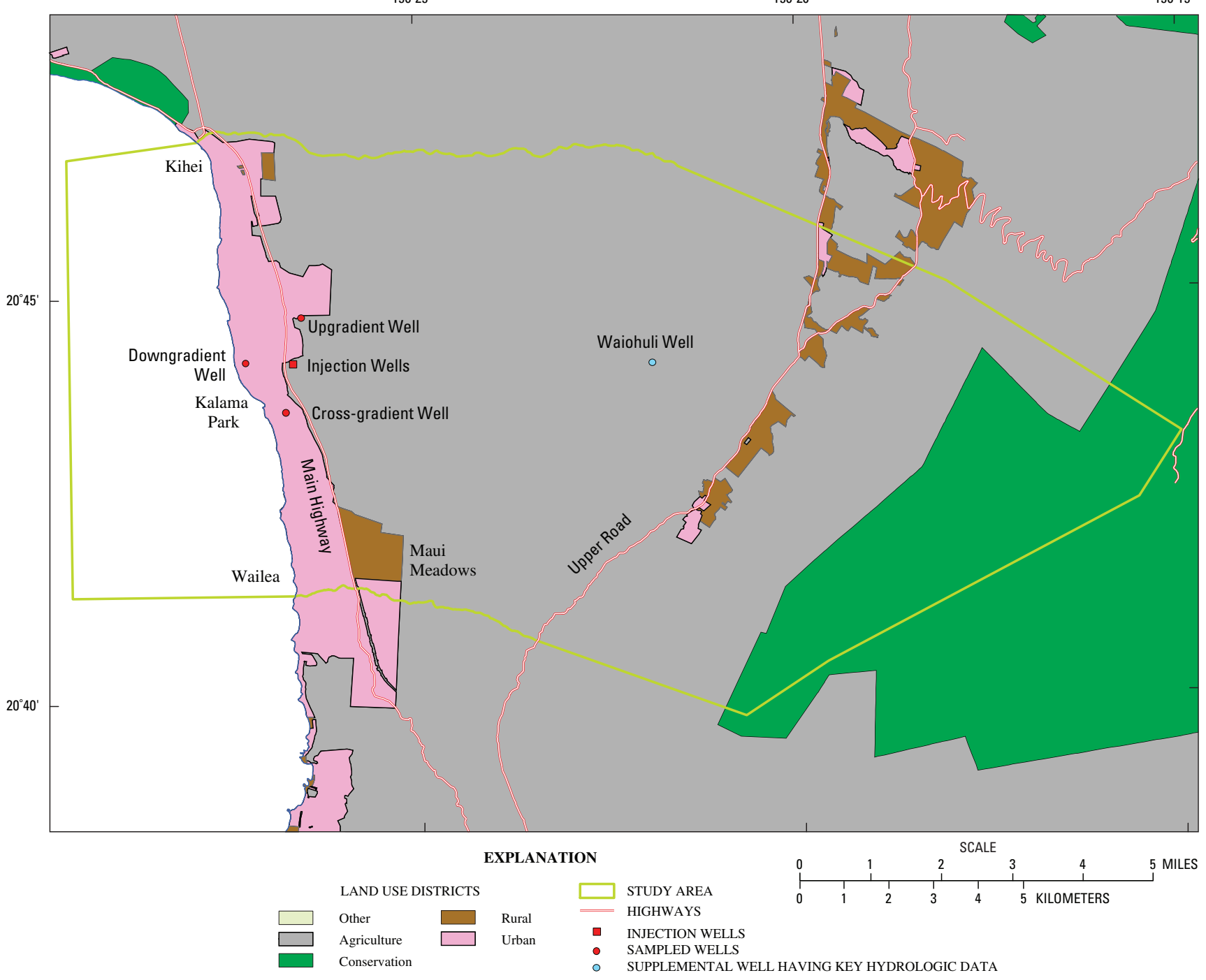

Figure 4. Map showing land-use districts, Kihei, Hawaii. Urban development is concentrated along the coast, forested conservation land occupies the far-inland part of the study area, and small inland parcels are designated as rural or urban. The large remaining area is designated as agricultural but very little of it is cultivated; it is mostly dryland forest, some of which is used for low-intensity ranching. (Modified from State of Hawaii, 2004a.) 


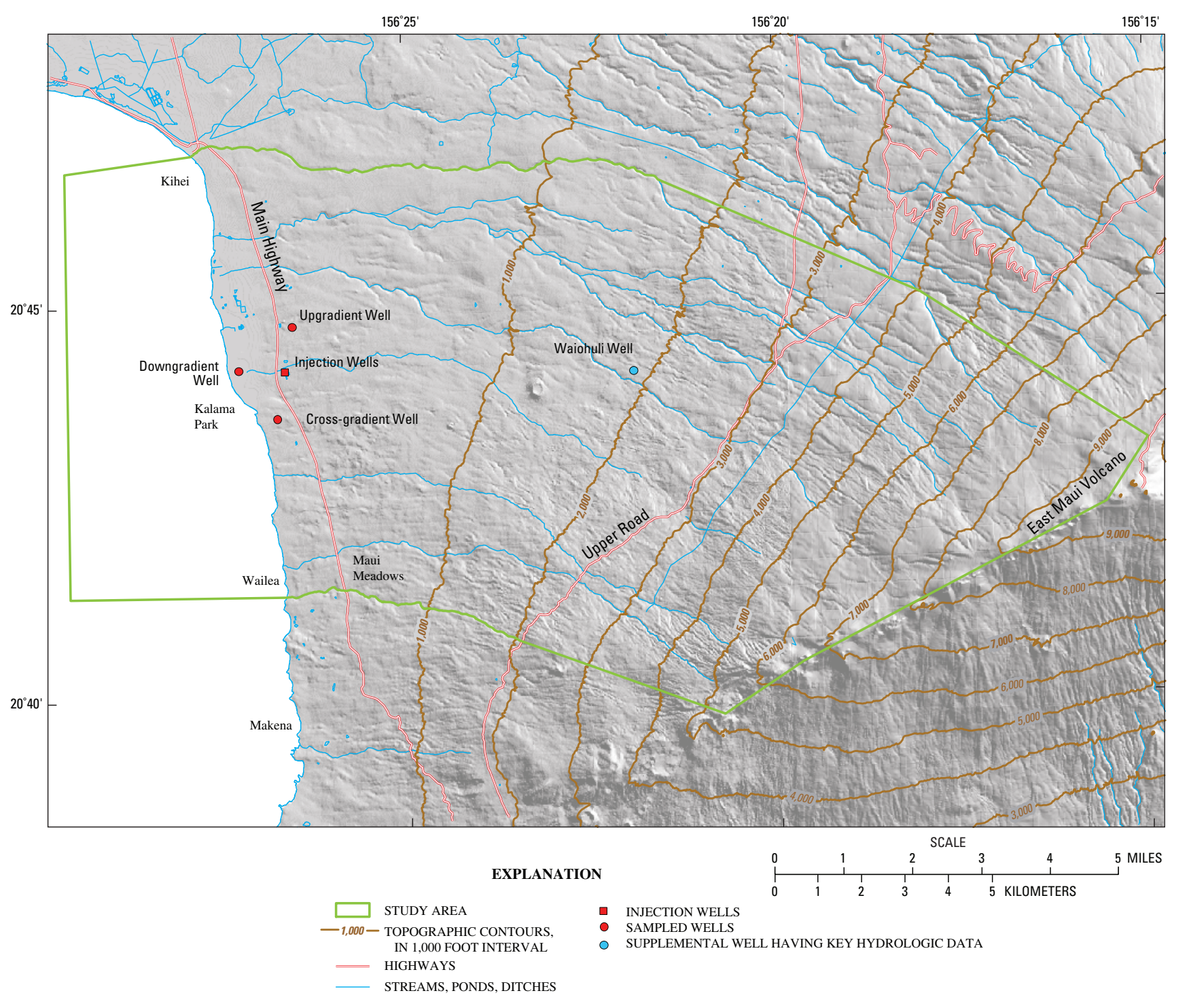

Figure 5. Map showing elevation contours, streams, and shaded-relief topography, Kihei, Hawaii. The inland edge of the study area is nearly 10,000 feet above sea level. Streams follow the general slope of the mountain flank to the west, and a flat coastal plain north of Kalama Park is dotted with ponds and wetlands. 


\section{Wastewater Reclamation, Reuse, and Disposal}

Public drinking water is imported by pipeline and consists of fresh ground water withdrawn from the Iao aquifer (Meyer and Presley, 2001) near Kahului on the north side of the island (fig. 1). Some ground water is withdrawn locally for landscape irrigation, mainly at larger resorts and mainly south of the study area, where withdrawals at Wailea and Makena resorts have averaged about $3 \mathrm{Mgal} / \mathrm{d}$ since the late 1980s.

Municipal wastewater is collected by sewer lines and conveyed to the Kihei Wastewater Reclamation Facility (fig. 6), which presently operates at a little more than half-capacity (its design capacity of $8 \mathrm{Mgal} / \mathrm{d}$ is sufficient to serve a population of 30,000). Wastewater inflows to the treatment plant have averaged about $4.5 \mathrm{Mgal} / \mathrm{d}$ in recent years (Scott Rollins, Maui Department of Public Works and Environmental Management, written commun., 2005). After treatment, about one-third of the reclaimed water $(1.5 \mathrm{Mgal} / \mathrm{d})$ is reused and the remainder $(3.0 \mathrm{Mgal} / \mathrm{d})$ is disposed by gravity-feed injection at three deep wells onsite. The first of these wells was activated in 1974, and the second and third wells were activated in 1990. The wells are about 50 feet apart, and well 1 is used most of the time, with the other two wells receiving effluent sporadically. Land surface at well 1 is 111 feet above sea level and the perforated injection interval is 122 feet long, from 47 to 169 feet below sea level. The other two wells extend about 25 feet deeper and have injection intervals about 20 feet longer than well 1 (County of Maui, 2004).

Wastewater is reclaimed to R-1 quality by activated sludge treatment, flocculation, filtration, and ultraviolet (UV) disinfection (Hawaii Water Environment Association, undated). The R-1 rating designates reclaimed water that has been sufficiently filtered and disinfected of bacteria and viruses that it can be used safely to water areas frequented by people (such as lawns, parks, and golf courses). Advanced nutrient removal lowers nitrogen concentration in reclaimed water to about $7 \mathrm{mg} / \mathrm{L}$ (milligrams per liter). A distribution piping system (figs. 6 and 7) carries reclaimed water throughout the community for reuse, primarily by lawn and landscape irrigation. Principal early users included Kalama Park, a seed-corn farm, a golf course, a school, and a community center; additional users have come on line or are planned. The reclaimed-water pipeline also supplies a network of hydrants for firefighting.

Prior to installation of sewers in the early 1970s, area households disposed of wastewater by using cesspools and septic systems. Although most properties were later connected to the Maui County sewer system, scattered lots without sewer connections remain (fig. 7). It is unclear how many of these have active disposal systems, and some lots may not represent as large a disposal source as might appear because they are undeveloped or are large, block-size lots with only one residence. In contrast, the Maui Meadows subdivision is a notable high-density concentration of unsewered lots, all or most having active septic systems or cesspools.

\section{Geology}

The geology of Maui was mapped by Stearns and Macdonald (1942) and there has been little revision since, save for renaming to better conform to modern stratigraphic nomenclature (Langenheim and Clague, 1987) and recent mapping of young lava flows (Dave Sherrod, USGS, written commun., 2004). Lava flows, cinder, and ash of the Kula Volcanics cover most of the study area (fig. 8, light tan), and wells near the coast likely penetrate only Kula Volcanics. Well records describe some wells as being in older Honomanu Basalt (which underlies Kula Volcanics) but typically no rationale or supporting evidence is noted for the attribution.

The Waiohuli well, upslope at altitude 1,864 feet, does penetrate Honomanu Basalt (fig. 9). Chemical analyses suggest that the well entered Honomanu Basalt at 939 feet above sea level after drilling through 925 feet of overlying Kula lavas (Gingerich and Sherrod, 2002). Whether wells tap Kula Volcanics or Honomanu Basalt is not critical in this study, as both formations are quite permeable owing to the steep mountain flank and minor weathering under arid climate. Upslope areas near the rift zone are blanketed by lavas, tephra, and associated cinder cones of the Hana Volcanics (fig. 8, blue). Hana Volcanics are classified as Pleistocene to Holocene in age, whereas Kula Volcanics and Honomanu Basalt both are Pleistocene (Langenheim and Clague, 1987). Sediments along the coast are Holocene.

Surficial geology near the coast defines two contrasting geomorphic provinces (fig. 10). The province south of Kalama Park has an alternating series of lava promontories and intervening sand beaches with submerged coral reefs offshore; the mountain flank of Kula lavas enters directly into the sea, with only a thin veneer of carbonate sands and sand dunes (fig. 10, purple). The province from Kalama Park north has a continuous sand beach, a broad fringing reef (fig. 6), and a flat coastal bench about a half-mile wide. The fringing reef curves in to shore and ends just south of Kalama Park, where the first lava promontory marks the start of the southern province. The coastal bench is covered by carbonate beach and dune sands and by stream-derived alluvium (fig. 10, orange) that likely contains a large fraction of silt and mud. The bench is delineated well by the 20 -foot elevation-contour line, which curves inland from the coast at the south end of Kalama Park. To the south, the 20-foot contour is much nearer the shore, particularly where Kula promontories extend into the sea. Drilling logs show that the sediments overlying volcanic rock are as much as several tens of feet thick (fig. 10). The sediments probably confine the volcanic-rock aquifer and impede ground-water discharge somewhat, perhaps diverting it slightly south where thin sand cover and high-permeability lava promontories permit easier outflow. Just offshore are Pleistocene and Holocene marine sediments that mostly comprise coral reefs and coralline sand and rubble. Farther offshore there are thick reef complexes with associated back-reef and lagoonal sand and mud (Gardner and others, 2000). 


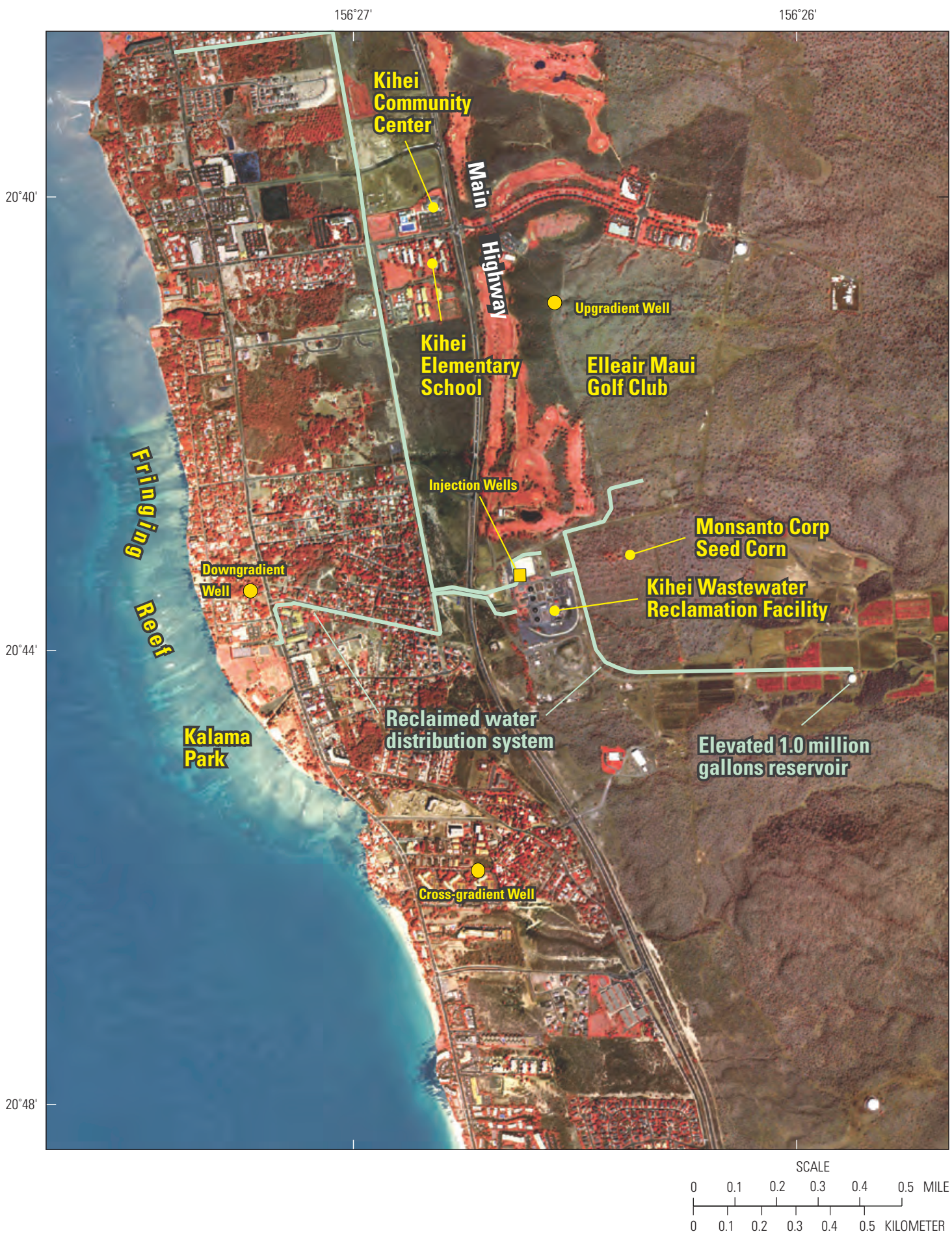

Figure 6. Aerial photomosaic showing Kihei Wastewater Reclamation Facility, reclaimed-water distribution system, and major reclaimed-water users, Kihei, Hawaii. Reclaimed water is applied for landscape irrigation at public facilities, a golf course, and a seed-corn farm (more users have come on line since this figure was prepared). Offshore, a shallow fringing reef borders the coast and ends just south of Kalama Park; from there south, the coast is marked by a succession of lava-rock promontories and intervening sand beaches. (Modified after Hawaii Water Environment Association, undated.) 


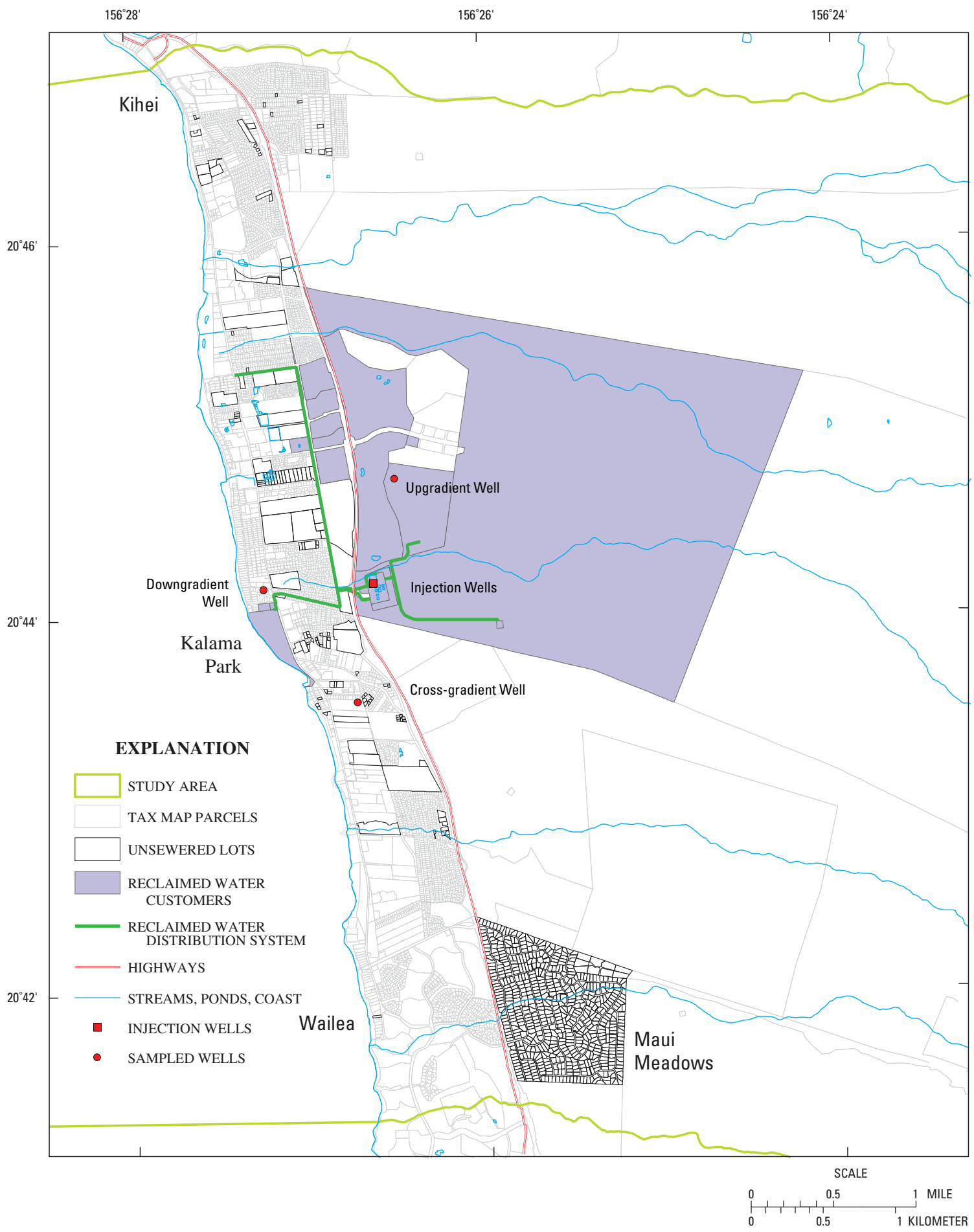

Figure 7. Map showing unsewered lots, the Kihei reclaimed-water distribution system, and major reclaimedwater users, Kihei, Hawaii. Most of the area is sewered, but there are scattered lots without sewer connections. Maui Meadows is a high-density residential subdivision in which most or all lots have active septic systems or cesspools. Reclaimed-water users are shown as shaded tax-map parcels (purple), although entire parcels are not necessarily irrigated. (Modified from digital maps provided by Maui Department of Public Works and Environmental Management.) 


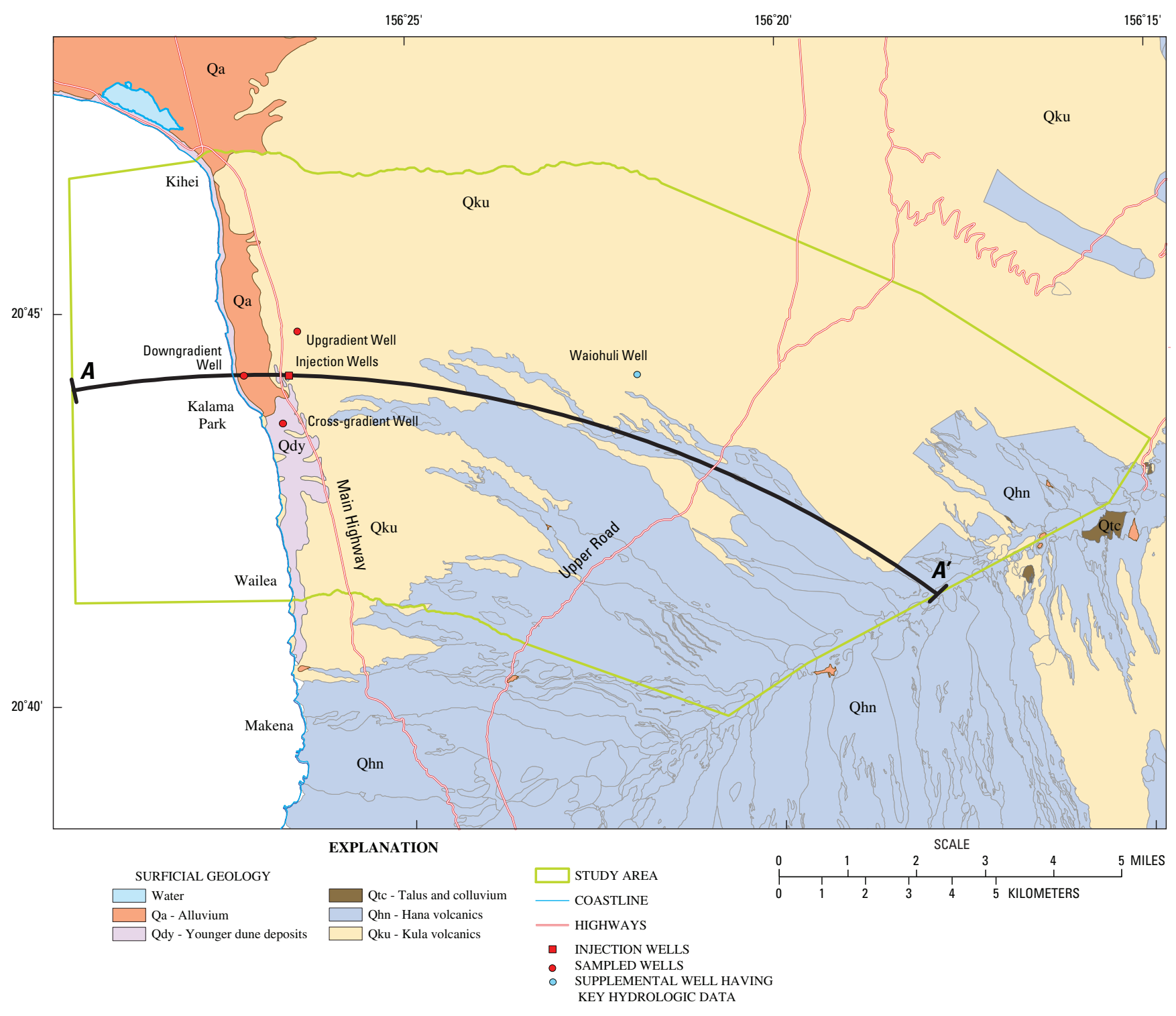

Figure 8. Map showing surface geology of the Kihei area, Hawaii. Lava flows of the Kula and Hana Volcanics are exposed over most of the study area. Alluvium and dune sands overlie the volcanics near the coast. (Modified from Stearns and Macdonald, 1942; digital version provided by David Sherrod, U.S. Geological Survey, 2005.) 


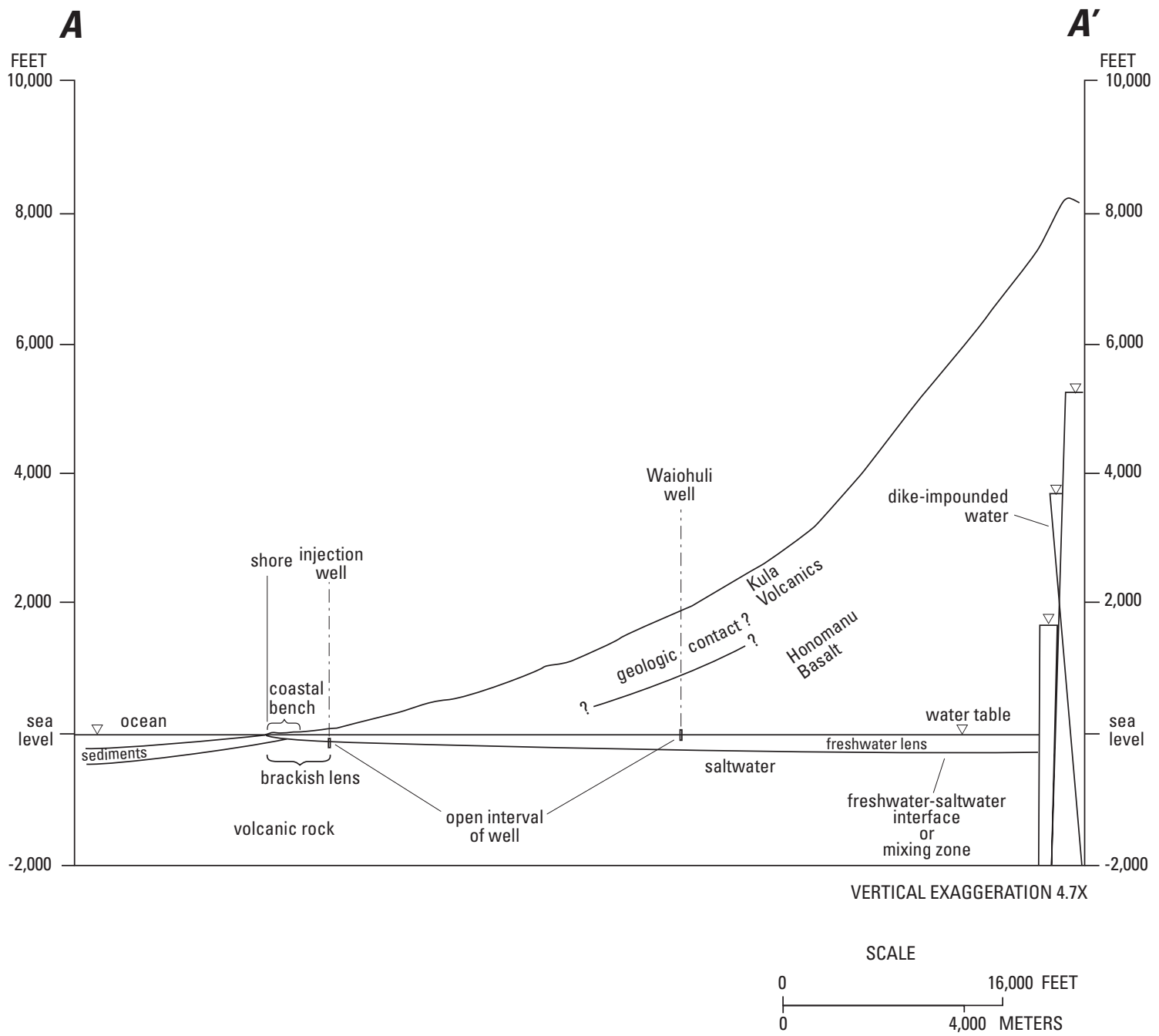

Figure 9. Cross section A-A' showing geology and hydrology at Kihei, Hawaii. A thin freshwater lens floats on saltwater within the mountain flank, although it is brackish near the shore. Farther inland, volcanic dikes may impound ground water to high levels. The Waiohuli well penetrated Kula Volcanics and encountered Honomanu Basalt at 939 feet above sea level. Figure 8 shows line of section.

\section{Ground-Water Flow System}

Infiltrating rainfall recharges a layer of fresh ground water or "freshwater lens" within the mountain flank (fig. 9). Ground-water recharge has been estimated by Shade (1999) to range from near-zero along the coast to as much as 31 inches annually along the summit ridge at the inland boundary of the study area (fig. 11). These rates are low compared to wetter parts of Maui where annual recharge can exceed 150 inches. Land use is predominantly nonurban in wetter areas above the main highway, so most recharge should have a nonurban or "background" water quality.

Recharge drives a fresh ground-water flow system from interior mountains westward to the shore within the freshwater lens. Water flows through a regional volcanic-rock aquifer consisting mostly of layered lava flows and then through sediments before discharging in coastal marshes, along the beach, and for a short distance offshore. Frictional resistance to flow builds up a low water table about a foot above sea level near the shore and more than 6 feet inland (fig. 12). 


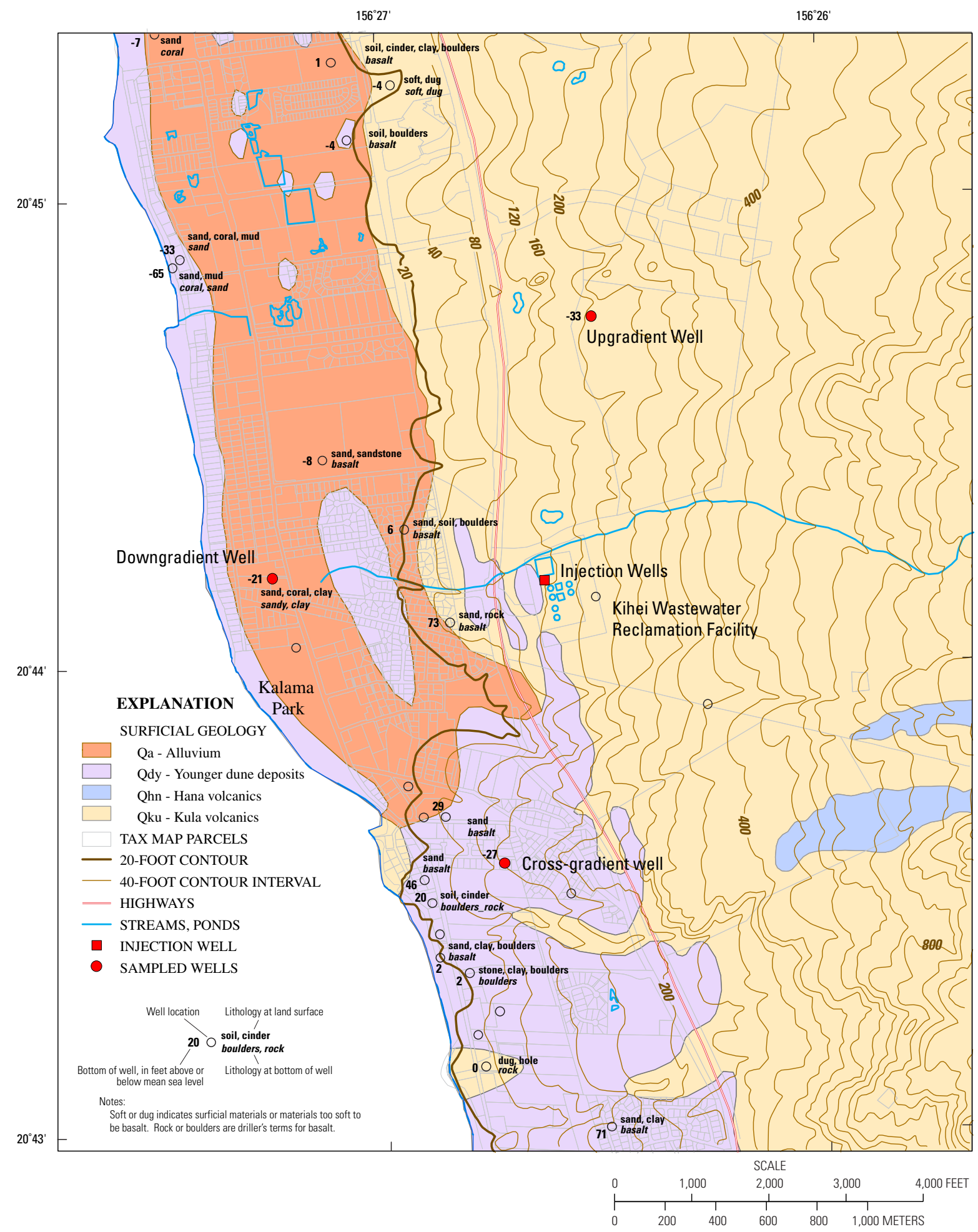

Figure 10. Map showing detailed surface geology of the coastal bench and selected information from subsurface drilling logs, Kihei, Hawaii. The low coastal bench can be discerned by the inland displacement of the 20 -foot elevation contour line in the northern part of the figure. Drilling logs for most wells indicate volcanic rock with a thin covering of soil or sediments, but nearshore wells on the coastal bench penetrated sediments several tens of feet thick without entering volcanic rock. (Modified from Stearns and Macdonald, 1942; digital version provided by David Sherrod, U.S. Geological Survey, 2005.) 


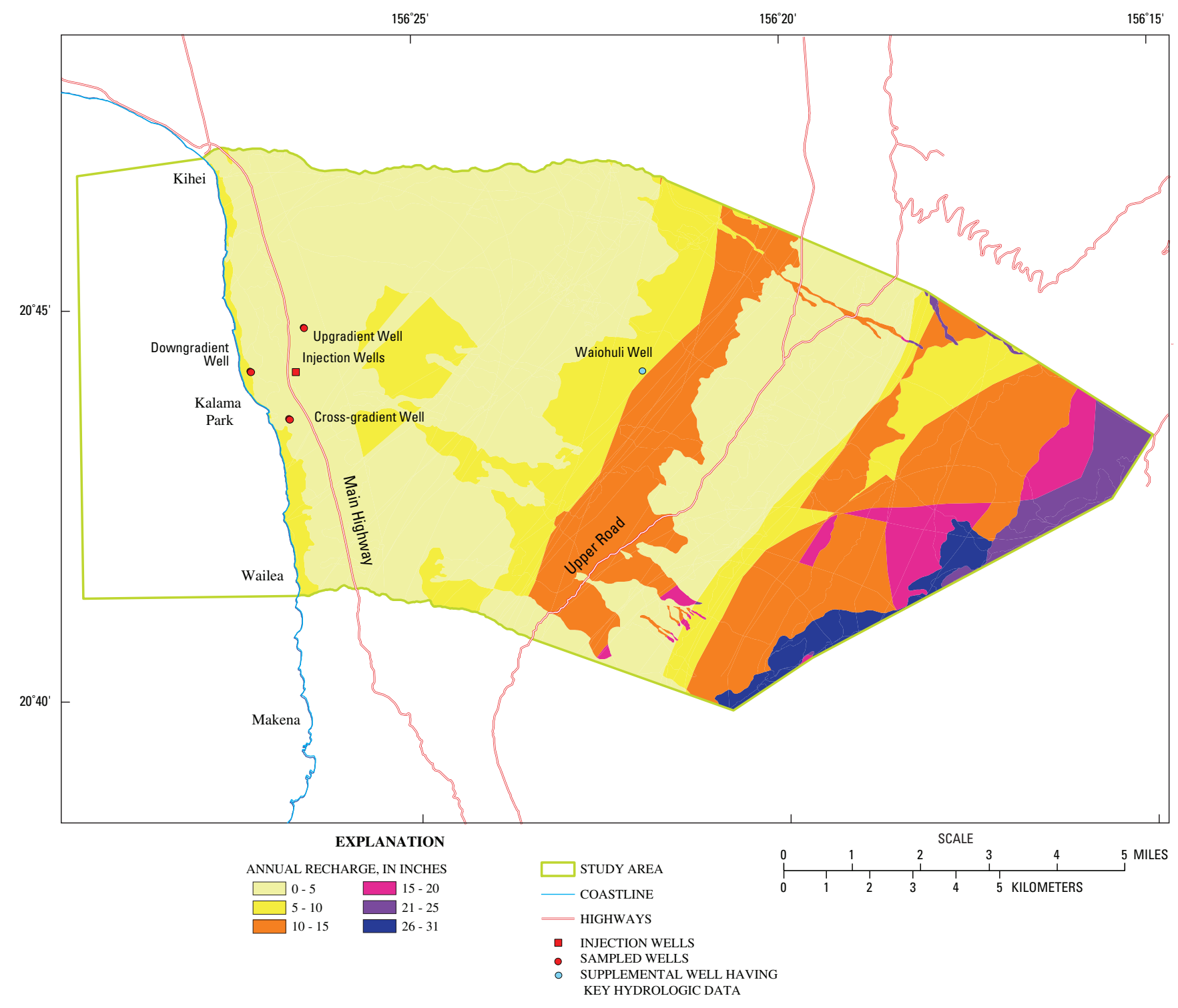

Figure 11. Map showing mean annual ground-water recharge, Kihei, Hawaii. Annual recharge ranges from less than 5 inches near the coast to as much as 31 inches at the inland extent of the study area. (Extracted from digital water budget of Shade, 1999.) 


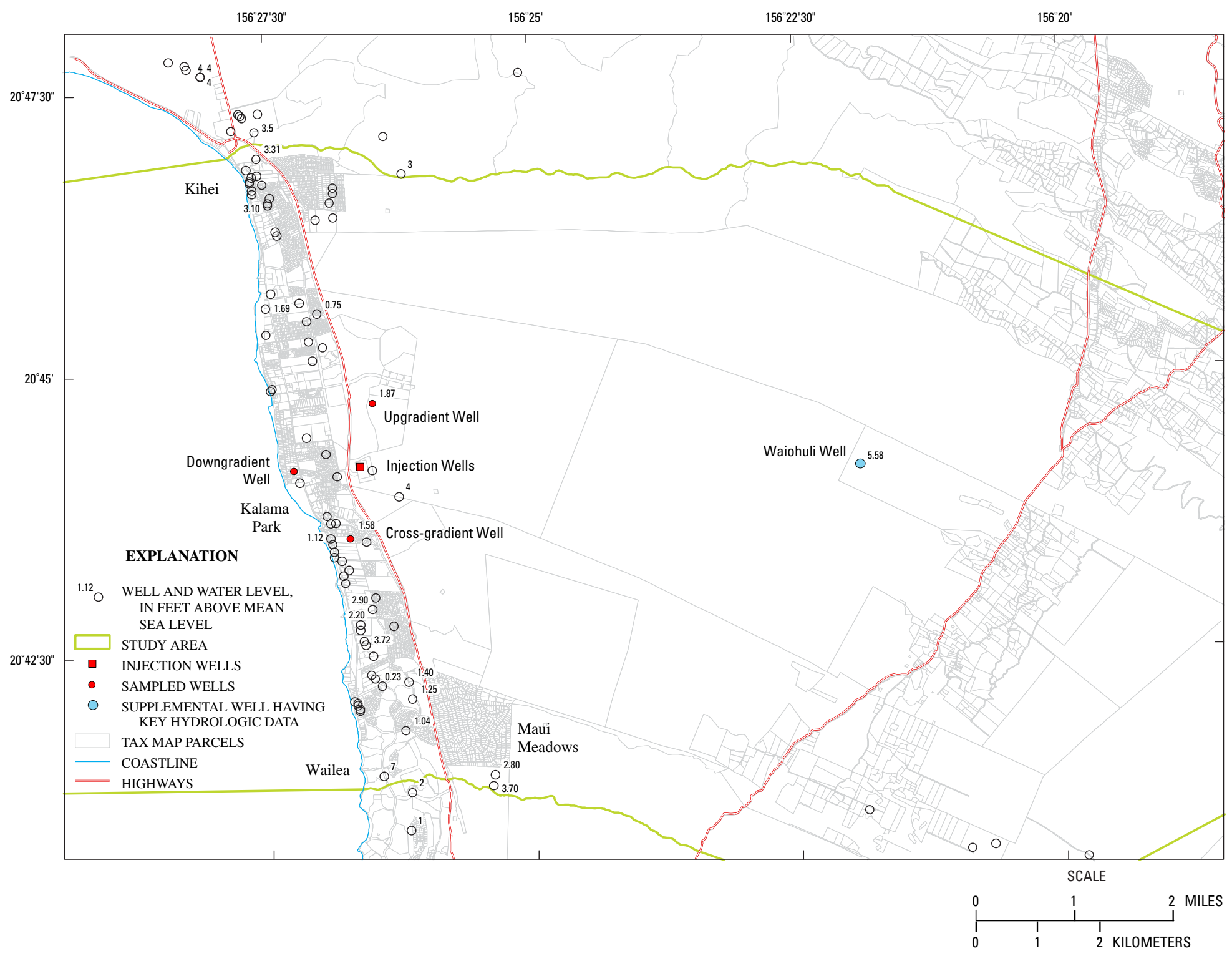

Figure 12. Map showing water levels in wells, Kihei, Hawaii. Ground-water levels are mostly 1 to 3 feet above sea level near the coast and nearly 6 feet above sea level at the Waiohuli well 6 miles inland. Water levels were measured by various parties at various times—often when a well was first drilled—and are not strictly comparable. (Data from State of Hawaii, 2002.) 
The freshwater lens floats on saltwater in the aquifer because it is less dense, much the way an iceberg floats in the sea. Because the density of seawater is $1 / 40^{\text {th }}$ greater than that of freshwater $\left(1.025 \mathrm{vs} .1 .000 \mathrm{~g} / \mathrm{cm}^{3}\right)$, freshwater theoretically should extend below sea level about 40 times the water-table height above sea level in the absence of mixing and vertical flow. This buoyancy principle is known in the field of coastal hydrology as the "Ghyben-Herzberg relation" (Stearns and Macdonald, 1942; Freeze and Cherry, 1979). Where the water table is 6 feet above sea level, this would amount to a freshwater depth 240 feet below sea level. However, several factors cause divergence from the idealized relation, among them the blending of freshwater and saltwater in a mixing or transition zone. In field studies, the theoretical Ghyben-Herzberg depth has been found to correspond roughly with 50 percent seawater concentration in the mixing zone, and much of that depth can be occupied by the upper half of the mixing zone, leaving a lesser thickness of freshwater. Mixing also extends laterally as well as vertically. Ground water within about a mile of the coast at Kihei is not entirely fresh but instead is brackish, having chloride concentrations of several hundred milligrams per liter (fig. 13), equivalent to several percent seawater. Because potable freshwater contains less than $250 \mathrm{mg} / \mathrm{L}$ chloride (about 1.3 percent seawater), ground water in the area generally is too salty for human consumption, at least near the coast.

Water in the freshwater lens and mixing zone will flow shoreward as long as there is a freshwater fraction in the mixture. This drives a circulatory saltwater flow field beneath the freshwater lens in which seawater is drawn into the aquifer at the sea bottom, then flows landward and upward into the mixing zone where it is entrained in the shoreward flow (Cooper, 1959). This circulatory saltwater flow system extends much deeper within the mountain flank than does the shallower shoreward flow system of the freshwater lens. Geothermal heating may also drive convective circulation within the mountain flank, a process known as endo-upwelling (Rougerie and Wauthy, 1993). Heating may be especially pronounced in the southwest rift zone, which constitutes the inland part of the study area. Large amounts of heat likely remain from past eruptions, the most recent of which was in 1790 (Langenheim and Clague, 1987). The volcanic-rock aquifer within the rift zone can be presumed to be subdivided into compartments by volcanic dikes (fig. 9). Dikes are thin, near-vertical sheets of massive rock that solidified in place after molten lava fed eruptive fissures or intruded surrounding rock without erupting. The dikes act as partial barriers to ground-water flow and impound water as much as several thousand feet above sea level (Takasaki and Mink, 1985). Hydrothermal convection cells can form within dike compartments (Ryan, 1996) and water in the compartments may be fresh, salty, or brackish (having been mixed by convective overturning). Although geothermal flow and dike compartmentalization are described here for completeness, they were not analyzed or modeled in this study.

Injection of treated wastewater effluent at the Maui County injection wells is expected to form an "injection plume" or "effluent plume" within the aquifer, extending from the wells to the coast and also a short distance inland. If injected effluent is less dense than the receiving water in the aquifer, the effluent will rise buoyantly (a buoyant injection plume) and displace other shoreward-flowing ground water (Heutmaker and others, 1977; Soicher and Peterson, 1996).

\section{Water Sampling for Nutrients and Chemical Tracers}

Water samples were collected to define nutrient concentrations in Kihei ground water and to identify chemical indicators for discriminating and tracing wastewater. Nitrogen concentration in treated wastewater effluent was six times the background concentration in upland ground water, and phosphorus concentration was 26 times background. A well downhill and downgradient from the injection wells appears to lie within the injected wastewater plume: it has nitrogen and phosphorus concentrations intermediate between wastewater and upland ground water and it provides evidence of nutrient attenuation and dilution with surrounding ground water as effluent flows to the coast. Sixteen pharmaceutical and organic wastewater compounds were detected in treated effluent and four were detected in the downgradient well. Stable isotopes of nitrogen and boron were found to be good wastewater tracers. Distinctive oxygen and hydrogen isotopic signatures in imported public-supply water persist in wastewater and are markedly different from ground water recharged locally. Nutrients in wastewater and upland ground water were characterized adequately for present interpretive needs, but the larger urban area was not sampled to define nutrient contributions from landscape fertilizers and other urban sources.

\section{Nutrient Sources}

Principal ground-water nutrient sources in the Kihei area are envisioned as follows, moving generally in a downhill direction:

- Atmospheric deposition, both natural and anthropogenic;

- Natural background sources in upland forest vegetation and soils;

- Farm and ranch sources upslope and along the upper road at 2,000 feet elevation;

- An injected wastewater effluent source at the Kihei Wastewater Reclamation Facility;

- Effluent-irrigation sources where reclaimed wastewater is applied as landscape irrigation;

- Fertilizer-irrigation sources where fertilizers are applied to lawns and landscaping; 


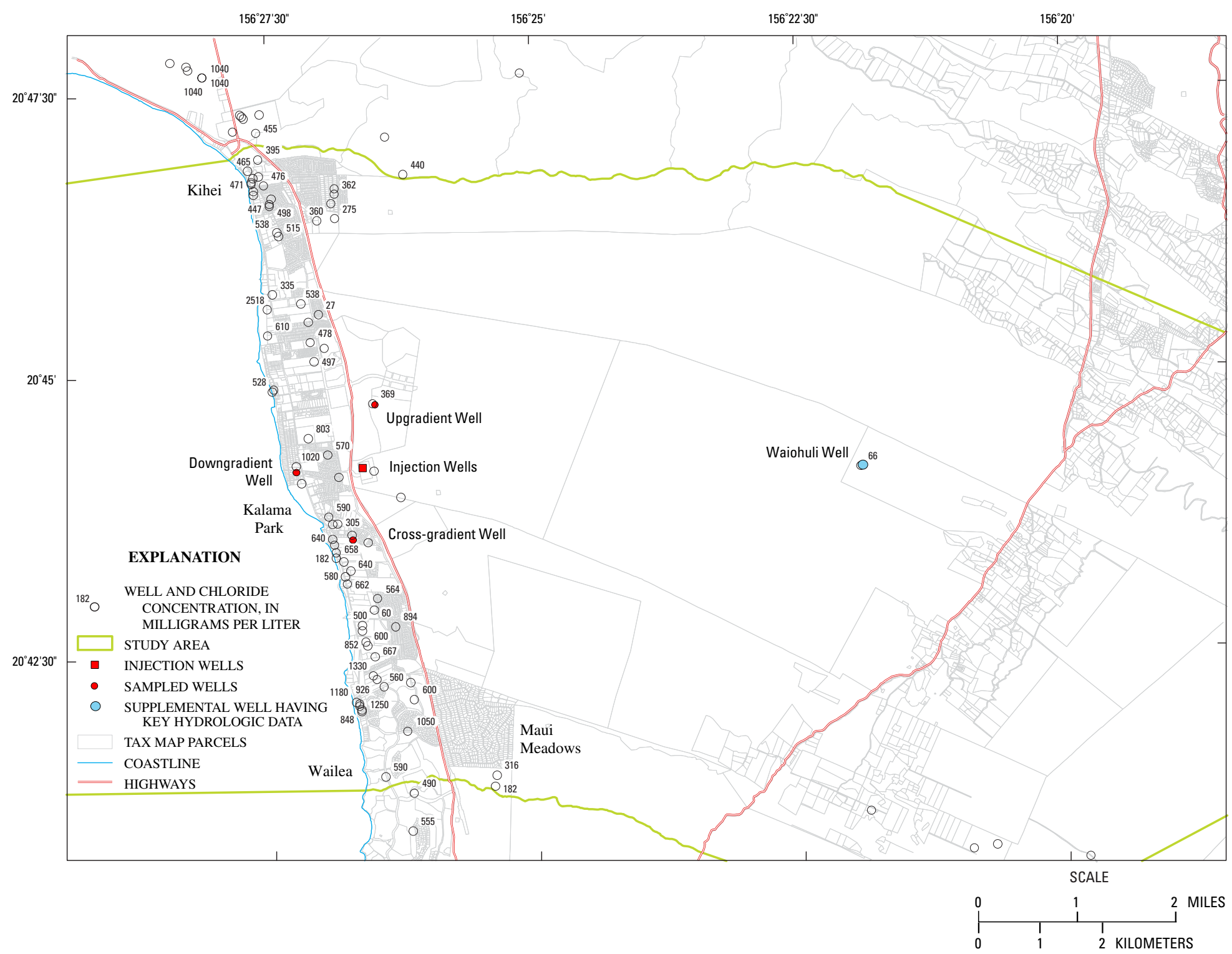

Figure 13. Map showing chloride concentrations in well water, Kihei, Hawaii. Chloride concentrations are mostly 300 to 1,000 milligrams per liter near the coast but only 66 milligrams per liter at the Waiohuli well 6 miles inland. Wells were sampled by various parties at various times-often when a well was first drilled—and data are not strictly comparable. (Data from State of Hawaii, 2002.) 
- Other urban sources, including cesspools, septic systems, leaking sewer lines, and pet and other animal waste.

The injected wastewater effluent is an identifiable and quantifiable point source of nutrients. The other sources can be considered as widespread nonpoint sources. They contribute nutrients over extensive areas, and the magnitude of their contributions to ground water can be estimated roughly at best. Cesspools, septic systems, and sewer leaks are "distributed point sources" in actuality, but their existence and location are not always known, particularly in the case of leaks. Because there may be many of these distributed sources, they are viewed here in aggregate, as nonpoint sources spread throughout the urban landscape. Although reclaimed wastewater is applied for landscape irrigation in the study area, return recharge of this water was not specifically targeted for sampling and so it is not emphasized in interpretation and discussion.

Streams also carry nutrient loads to coastal waters in dissolved form, sorbed to sediment, and as vegetation litter and particles. Airborne sources of nutrients to the area include atmospheric gases dissolved in precipitation, automobile emissions, gas and aerosol emissions from active volcanoes on Hawaii Island, and atmospheric dust from Hawaii and the continents (mainly Asia). Airborne nutrients are incorporated in soils and recharge and also are deposited directly in the ocean.

\section{Water-Chemistry Sampling}

Water samples were collected November 15-17, 2004, following standard protocols of the U.S. Geological Survey (U.S. Geological Survey, variously dated). The sampling strategy was to localize sampling in the vicinity of Maui County injection wells to help define the extent of the injected wastewater plume and to run an extensive suite of chemical analyses to discriminate a wastewater component in ground water. This localized sampling strategy came at the expense of an alternate strategy of sampling more wells up and down the coast (to better characterize nutrient contributions from the larger urban area) while analyzing for fewer constituents (and resulting in less-definitive wastewater discrimination).

Five sources of water were sampled, including three landscape-irrigation wells (fig. 7):

- Treated wastewater effluent (reclaimed wastewater), sampled at the Kihei treatment plant;

- Tap water (imported public-supply water), also sampled at the treatment plant;

- An upgradient well, north and slightly uphill of the injection wells and thought to represent background water quality in ground water flowing from the interior uplands;
- A downgradient well, downhill from the injection wells and thought to lie within the shoreward-flowing wastewater effluent plume;

- A cross-gradient well, south and slightly downhill of the injection wells, possibly lying within or near the edge of the injection plume, and possibly affected by residential housing just uphill.

[The terms "upgradient" and "downgradient" are directional references oriented to the water-table slope and prevailing ground-water flow direction. Upgradient is in the uphill or inland direction, whereas downgradient is down the watertable slope, in the direction of flow and towards shore.]

The upgradient well serves to define a "background" water quality that may approximate "natural background" but is not entirely natural owing to some amount of nutrients and other constituents being contributed from farms and rural homesteads along the upper road at 3,000 feet elevation (figs. $4,5)$. Forested conservation areas farther uphill would have true natural background water quality, but these areas were not sampled.

The downgradient well is expected to lie within the wastewater injection plume extending shoreward from the county injection wells. However, the well is shallow, extending only 21 feet below sea level, and is open to sand and clay but does not extend into the volcanic-rock aquifer. At least two hypotheses can be proposed for this well. One is that it withdraws injected effluent, though perhaps modified by dilution and various chemical processes. The other is that it withdraws water recharged locally and whose chemistry is determined by the urban surroundings, possibly including cesspools or septic systems, leaking water or sewer lines, landscape fertilizers, and other urban sources of nutrients and chemicals. Both hypotheses may be true, as they are not exclusive.

Methods of analysis are listed in table 1 and results of the analyses are reported in tables 2 to 4 . Table 2 is a comprehensive listing of inorganic constituents, isotopic and water-dating tracers, and well characteristics. Table 3 lists pharmaceuticals, such as prescription and over-the-counter drugs that are excreted following ingestion and thus serve as wastewater indicators or tracers. Table 4 lists organic wastewater compounds such as detergents, solvents, fire retardants, insect repellants, and fragrances from personal care products (soaps, shampoos, deodorants, perfumes). These compounds enter the wastewater stream through laundering, bathing, use and disposal of household cleaning products, and industrial discharges.

\section{Pharmaceuticals and Organic Wastewater Compounds}

Pharmaceuticals and organic wastewater compounds were detected in treated effluent and the downgradient well but not in the upgradient or cross-gradient wells (tables 3 and 4; tap water was not analyzed). Far fewer compounds were detected 
Table 1. Methods of water-quality analysis for samples collected at Kihei, Hawaii, November 15-17, 2004.

[USGS, U.S. Geological Survey; O, oxygen; H, hydrogen; N, nitrogen; B, boron; Sr, strontium; CFC, chlorofluorocarbon; SF6, sulfur hexafluoride; --, not applicable]

\begin{tabular}{|c|c|c|}
\hline Type of analysis & USGS method number & USGS Laboratory \\
\hline Nutrients & Schedule 2752 & National Water Quality Laboratory ${ }^{1}$ \\
\hline Dissolved organic carbon & Lab code 2613 & National Water Quality Laboratory \\
\hline Organic wastewater compounds & Schedule 1433 & National Water Quality Laboratory \\
\hline Major inorganic ions & Schedule 2750 & National Water Quality Laboratory \\
\hline Stable isotopes of $\mathrm{O}, \mathrm{H}$ in water & Lab code 1142 & Reston Stable Isotope Laboratory ${ }^{2}$ \\
\hline Stable isotopes of $\mathrm{N}, \mathrm{O}$ in dissolved nitrate & Lab code 2900 & Reston Stable Isotope Laboratory \\
\hline Stable isotopes of $\mathrm{N}$ in dissolved ammonium & Lab code 2898 & Reston Stable Isotope Laboratory \\
\hline Stable isotopes of $\mathrm{B}, \mathrm{Sr}$ in dissolved boron and strontium & -- & Menlo Park Stable Isotope Laboratory ${ }^{3}$ \\
\hline Physical properties & -- & Determined in field with water-quality meter ${ }^{7}$ \\
\hline \multicolumn{3}{|l|}{${ }^{1} \mathrm{http} / / /$ wwwnwql.cr.usgs.gov/ } \\
\hline \multicolumn{3}{|l|}{${ }^{2} \mathrm{http}: / /$ isotopes.usgs.gov/ } \\
\hline \multicolumn{3}{|l|}{${ }^{3}$ Thomas D. Bullen, Branch of Regional Research } \\
\hline \multicolumn{3}{|l|}{${ }^{4}$ http://water.usgs.gov/lab/ } \\
\hline \multicolumn{3}{|l|}{${ }^{5} \mathrm{http} / / /$ water.usgs.gov/lab/sf6/ } \\
\hline \multicolumn{3}{|l|}{${ }^{6} \mathrm{http}: / /$ water.usgs.gov/lab/dissolved-gas/ } \\
\hline${ }^{7}$ http://pubs.water.usgs.gov/twri9A & & \\
\hline
\end{tabular}

in the downgradient well than in effluent. If well water contains a substantial effluent component, this suggests that many compounds have been removed, degraded, or diluted below detection levels in the aquifer.

Pharmaceuticals and organic wastewater compounds have been used in various studies to infer the presence of wastewater (Barber and others, 1988; Boyd and Furlong, 2002; Kolpin and others, 2002; Cahill and others, 2004; Glassmeyer and others, 2005; Barber and others, 2006) and might be expected to be useful in delineating the injected wastewater plume at Kihei. These chemicals raise no human-health concern at Kihei, because ground water is not developed for drinkingwater supply. Also notable is that chemical concentrations are quite low, mostly near or below reporting limits.

Of the 24 pharmaceuticals analyzed (table 3 ), four compounds were detected in treated wastewater effluent: carbamazepine, cotinine, diphenhydramine, and trimethoprim. These are, respectively, an antiepileptic, a nicotine metabolite, an antihistamine, and an antibiotic. One other compound, the antianginal metabolite dehydronifedipine, was present in two samples but also was present in laboratory blanks and did not meet the criterion for conclusive detection (that is, the sample concentration was not more than ten times the concentration in the blanks). Only one pharmaceutical was conclusively detected in ground water: carbamazepine in the downgradient well. Carbamazepine is one of the more likely pharmaceuticals to be detected in ground water, apparently because it is more resistant to degradation than others. It has been found to persist during the ground-water recharge process (Drewes and others, 2003).

One might expect some of the other 24 pharmaceuticals to have been in the wastewater stream, at least initially. It may be that they were not detected in treated effluent either because they were absent in raw wastewater, were diluted below laboratory reporting levels, or were removed during various stages of wastewater treatment. Notably, caffeine was not detected (it is a stimulant in coffee, soft drinks, and other products). Caffeine has been detected in streams and rivers (Kolpin and others, 2002) and in shallow wells affected by septic waste (Verstraeten and others, 2005). However, it degrades readily and tends not to persist in ground water (Drewes and others, 2003). Nondetection of caffeine in Kihei effluent likely reflects removal during treatment.

Of the 62 organic wastewater compounds analyzed, 13 were detected in treated wastewater effluent (table 4). They include disinfectants, fragrances, fire retardants, the insect 
Table 2. Inorganic chemistry of tap water, wastewater effluent, and untreated ground water, Kihei, Hawaii, November 15-17, 2004.

[Feet msl, feet above or below mean sea level; <, not detected at the minimum reporting level shown (non-detects are in light gray); --, not analyzed or not applicable; E, estimated; mg/L, milligrams per liter; $\mu \mathrm{g} / \mathrm{L}$, micrograms per liter; $\mu \mathrm{S} / \mathrm{cm}$, microSiemens per centimeter; deg.C, degrees Celsius; cc STP/L, cubic centimeters at standard temperature and pressure per liter; $\delta$, delta notation for isotopic compositions; per mil, parts per thousand; CFC, chlorofluorocarbon; SF6, sulfur hexafluoride; apparent recharge dates assume simple piston-flow displacement; Pcode, U.S. Geological Survey parameter code. Nutrients, major ions, and trace elements are from USGS National Water Quality Laboratory. Dissolved gases, recharge dates, and stable isotopes are from USGS Reston laboratories except boron and strontium isotopes, which are from USGS Menlo Park laboratory]

\begin{tabular}{|c|c|c|c|c|c|c|c|c|}
\hline Constituent or site attribute & Units & Tap water & $\begin{array}{c}\text { Wastewater } \\
\text { effluent }\end{array}$ & $\begin{array}{c}\text { Downgradient } \\
\text { well }\end{array}$ & $\begin{array}{c}\text { Cross-gradient } \\
\text { well }\end{array}$ & $\begin{array}{l}\text { Upgradient } \\
\text { well }\end{array}$ & $\begin{array}{c}\text { Symbol or } \\
\text { abbreviation }\end{array}$ & Parameter code \\
\hline State well number & -- & -- & $6-4426.01$ & 6-4427-04 & 6-4326-09 & $6-4426-03$ & -- & -- \\
\hline $\begin{array}{r}\text { USGS site identification } \\
\text { number }\end{array}$ & -- & 204411156263801 & 204411156263800 & 204423156272501 & 204334156264301 & 204456156264101 & -- & -- \\
\hline Date & -- & 17-Nov-2004 & 17-Nov-2004 & 15-Nov-2004 & 15-Nov-2004 & 16-Nov-2004 & -- & -- \\
\hline Time & -- & 1000 & 1100 & 1100 & 1500 & 1100 & -- & -- \\
\hline Altitude of land surface & feet msl & -- & -- & 3 & 64 & 124 & -- & -- \\
\hline Top of well open interval & feet $\mathrm{msl}$ & -- & -- & -15 & -7 & -3 & -- & -- \\
\hline Bottom of well open interval & feet $\mathrm{msl}$ & -- & -- & -21 & -31 & -33 & -- & -- \\
\hline $\begin{array}{r}\text { Lithology in well open } \\
\text { interval }\end{array}$ & -- & -- & -- & Sand, coral, clay & Basalt & Basalt & -- & -- \\
\hline Nutrients & Units & Tap water & Effluent & Downgradient & Cross-gradient & Upgradient & Symbol & P code \\
\hline Nitrogen, ammonia, as $\mathrm{N}$ & $\mathrm{mg} / \mathrm{L}$ & $<.04$ & .26 & .09 & $<.04$ & $<.04$ & $\mathrm{NH}_{4}$ & P00608 \\
\hline $\begin{array}{l}\text { Nitrogen, nitrite plus nitrate, } \\
\text { as } \mathrm{N}\end{array}$ & $\mathrm{mg} / \mathrm{L}$ & .579 & 6.32 & 3.21 & 1.54 & 1.11 & $\mathrm{NO}_{2}+\mathrm{NO}_{3}$ & P00631 \\
\hline Nitrogen, nitrite, as $\mathrm{N}$ & $\mathrm{mg} / \mathrm{L}$ & $<.008$ & .101 & .008 & $<.008$ & $<.008$ & $\mathrm{NO}_{2}$ & P00613 \\
\hline $\begin{array}{l}\text { Nitrogen, total dissolved, as } \\
\mathrm{N}(\text { nitrate }+ \text { nitrite }+ \text { am- } \\
\text { monia + organic-N) }\end{array}$ & $\mathrm{mg} / \mathrm{L}$ & .600 & 7.33 & 3.49 & 1.54 & 1.17 & TDN & P62854 \\
\hline $\begin{array}{l}\text { Phosphorus, ortho, dissolved, } \\
\text { as P }\end{array}$ & $\mathrm{mg} / \mathrm{L}$ & .096 & 1.70 & .186 & .051 & .058 & $\mathrm{PO}_{4}$ & P00671 \\
\hline $\begin{array}{l}\text { Phosphorus, total, dissolved, } \\
\text { as P }\end{array}$ & $\mathrm{mg} / \mathrm{L}$ & .106 & 1.72 & .191 & .059 & .067 & TDP & P00666 \\
\hline Carbon, organic, dissolved & $\mathrm{mg} / \mathrm{L}$ & -- & 3.9 & 1.3 & $<.3$ & E. 2 & DOC & P00681 \\
\hline Physical Properties & Units & Tap water & Effluent & Downgradient & Cross-gradient & Upgradient & Symbol & P code \\
\hline $\begin{array}{l}\text { Total dissolved solids, resi- } \\
\text { due on evaporation }\end{array}$ & $\mathrm{mg} / \mathrm{L}$ & 185 & 566 & 1780 & 1250 & 909 & TDS & P70300 \\
\hline $\begin{array}{l}\text { Specific conductance, field } \\
\text { meter }\end{array}$ & $\mu \mathrm{S} / \mathrm{cm}$ & 276 & 960 & 3160 & 2300 & 1610 & Sp. Cond. & P00095 \\
\hline Oxygen, field meter & $\mathrm{mg} / \mathrm{L}$ & 8.2 & 1.6 & 0.6 & 8.2 & 7.8 & $\mathrm{DO}$ & P00300 \\
\hline $\begin{array}{l}\text { Oxygen saturation, field } \\
\text { meter }\end{array}$ & percent & 100 & 21 & 8 & 93 & 88 & DOsat & P00301 \\
\hline $\mathrm{pH}$, field meter & $\mathrm{pH}$ units & 7.3 & 6.9 & 7.4 & 7.8 & 8.2 & $\mathrm{pH}$ & P00400 \\
\hline Alkalinity & $\mathrm{mg} / \mathrm{L}$ & 63 & 96 & 220 & 65 & 69 & Alk & P39086 \\
\hline Temperature, field meter & deg. C & 25.0 & 27.5 & 27.0 & 21.0 & 20.5 & $\mathrm{~T}$ & P00010 \\
\hline $\begin{array}{l}\text { Barometric pressure, field } \\
\text { meter }\end{array}$ & $\mathrm{mm} \mathrm{Hg}$ & 758 & 756 & 761 & 756 & 757 & $\mathrm{BP}$ & P00025 \\
\hline
\end{tabular}


Table 2. Inorganic chemistry of tap water, wastewater effluent, and untreated ground water, Kihei, Hawaii, November 15-17, 2004-Continued.

\begin{tabular}{|c|c|c|c|c|c|c|c|c|}
\hline $\begin{array}{l}\text { Dissolved gases \& recharge } \\
\text { dates }\end{array}$ & Units & Tap water & Effluent & Downgradient & Cross-gradient & Upgradient & Symbol & P code \\
\hline Nitrogen & $\mathrm{mg} / \mathrm{L}$ & -- & 17.26 & 17.08 & 15.73 & 15.73 & $\mathrm{~N}_{2}$ & -- \\
\hline Argon & $\mathrm{mg} / \mathrm{L}$ & -- & 0.54 & 0.67 & 0.58 & 0.58 & $\mathrm{Ar}$ & -- \\
\hline Oxygen & $\mathrm{mg} / \mathrm{L}$ & -- & 0.75 & 0.06 & 5.52 & 6.09 & $\mathrm{O}_{2}$ & -- \\
\hline Carbon dioxide & $\mathrm{mg} / \mathrm{L}$ & -- & 20.68 & 11.84 & 3.26 & 1.76 & $\mathrm{CO}_{2}$ & -- \\
\hline Methane & $\mathrm{mg} / \mathrm{L}$ & -- & 0 & 0 & 0 & 0 & $\mathrm{CH}_{4}^{2}$ & -- \\
\hline $\begin{array}{l}\text { Recharge temperature, } \\
\text { computed }\end{array}$ & deg. C & -- & 28.82 & 10.39 & 18.52 & 18.47 & $-{ }^{4}$ & -- \\
\hline Excess air, computed & cc STP/L & -- & 4.43 & -1.01 & 0.37 & 0.35 & -- & -- \\
\hline CFC apparent recharge date & year & -- & -- & 1976 & 1970 & 1970 & -- & -- \\
\hline SF6 apparent recharge date & year & -- & -- & 1986 & 1980 & 1979 & -- & -- \\
\hline Stable isotopes & Units & Tap water & Effluent & Downgradient & Cross-gradient & Upgradient & Symbol & P code \\
\hline Hydrogen $2 / 1$ ratio in water & per mil & -14.2 & -15.1 & -21.6 & -44.0 & -43.2 & $\delta 2 \mathrm{H}$ & -- \\
\hline Oxygen $18 / 16$ ratio in water & per mil & -3.54 & -3.61 & -4.40 & -6.85 & -6.77 & $\delta 180$ & -- \\
\hline $\begin{array}{l}\text { Oxygen } 18 / 16 \text { ratio in dis- } \\
\text { solved nitrate }\end{array}$ & per mil & 2.55 & 8.18 & 11.30 & 2.13 & 1.09 & $\delta 18 \mathrm{O}$ in $\mathrm{NO} 3$ & -- \\
\hline $\begin{array}{l}\text { Nitrogen } 15 / 14 \text { ratio in dis- } \\
\text { solved nitrate }\end{array}$ & per mil & 2.36 & 14.68 & 23.07 & 5.27 & 5.09 & $\delta 15 \mathrm{~N}$ in $\mathrm{NO} 3$ & -- \\
\hline $\begin{array}{l}\text { Nitrogen } 15 / 14 \text { ratio in dis- } \\
\text { solved ammonium }\end{array}$ & per mil & -- & 27.34 & 17.25 & -- & -- & $\delta 15 \mathrm{~N}$ in $\mathrm{NH} 4$ & -- \\
\hline $\begin{array}{l}\text { Boron } 11 / 10 \text { ratio in dis- } \\
\text { solved boron }\end{array}$ & per mil & 47.6 & 32.2 & 29.8 & 45.2 & 49.1 & $\delta 11 \mathrm{~B}$ & -- \\
\hline $\begin{array}{l}\text { Stontium } 87 / 86 \text { ratio in dis- } \\
\text { solved strontium }\end{array}$ & ratio & 0.704 & 0.706 & 0.708 & 0.706 & 0.706 & $87 \mathrm{Sr} / 86 \mathrm{Sr}$ & -- \\
\hline $\begin{array}{l}\text { Boron, Menlo Park labora- } \\
\text { tory }\end{array}$ & $\mu \mathrm{g} / \mathrm{L}$ & 28 & 195 & 440 & 210 & 160 & B & -- \\
\hline $\begin{array}{l}\text { Strontium, Menlo Park } \\
\text { laboratory }\end{array}$ & $\mu \mathrm{g} / \mathrm{L}$ & 89 & 168 & 800 & 290 & 180 & $\mathrm{Sr}$ & -- \\
\hline Major ions & Units & Tap water & Effluent & Downgradient & Cross-gradient & Upgradient & Symbol & P code \\
\hline Calcium & $\mathrm{mg} / \mathrm{L}$ & 13.1 & 22.7 & 58.0 & 19.7 & 11.6 & $\mathrm{Ca}$ & P00915 \\
\hline Magnesium & $\mathrm{mg} / \mathrm{L}$ & 8.61 & 17.6 & 61.4 & 34.4 & 22.2 & $\mathrm{Mg}$ & P00925 \\
\hline Potassium & $\mathrm{mg} / \mathrm{L}$ & 1.92 & 13.6 & 33.4 & 25.6 & 18.6 & $\mathrm{~K}$ & P00935 \\
\hline Sodium & $\mathrm{mg} / \mathrm{L}$ & 22.4 & 130 & 478 & 360 & 258 & $\mathrm{Na}$ & P00930 \\
\hline Bromide & $\mathrm{mg} / \mathrm{L}$ & .032 & .48 & 2.60 & 2.17 & 1.46 & $\mathrm{Br}$ & P71870 \\
\hline Chloride & $\mathrm{mg} / \mathrm{L}$ & 35.8 & 195 & 788 & 612 & 412 & $\mathrm{Cl}$ & P00940 \\
\hline Fluoride & $\mathrm{mg} / \mathrm{L}$ & .15 & .6 & .4 & .2 & .2 & $\mathrm{~F}$ & P00950 \\
\hline Silica & $\mathrm{mg} / \mathrm{L}$ & 48.0 & 50.1 & 42.5 & 33.2 & 35.4 & $\mathrm{Si}$ & P00955 \\
\hline Sulfate & $\mathrm{mg} / \mathrm{L}$ & 6.58 & 36.6 & 119 & 83.9 & 56.3 & $\mathrm{SO}_{4}$ & P00945 \\
\hline Bicarbonate & $\mathrm{mg} / \mathrm{L}$ & 77 & 117 & 268 & 79 & 84 & $\mathrm{HCO}_{3}$ & $\mathrm{P} 00453$ \\
\hline
\end{tabular}


Table 2. Inorganic chemistry of tap water, wastewater effluent, and untreated ground water, Kihei, Hawaii, November 15-17, 2004-Continued.

\begin{tabular}{|c|c|c|c|c|c|c|c|c|}
\hline Trace elements & Units & Tap water & Effluent & Downgradient & Cross-gradient & Upgradient & Symbol & P code \\
\hline Aluminum & $\mu \mathrm{g} / \mathrm{L}$ & -- & 23 & 6 & 4 & 5 & $\mathrm{Al}$ & P01106 \\
\hline Antimony & $\mu \mathrm{g} / \mathrm{L}$ & -- & .54 & E. 25 & $<.20$ & $<.20$ & $\mathrm{Sb}$ & P01095 \\
\hline Arsenic & $\mu \mathrm{g} / \mathrm{L}$ & -- & E.2 & 4.2 & $<.2$ & $<.2$ & As & P01000 \\
\hline Barium & $\mu \mathrm{g} / \mathrm{L}$ & -- & 3 & 18 & 15 & 5 & $\mathrm{Ba}$ & P01005 \\
\hline Beryllium & $\mu \mathrm{g} / \mathrm{L}$ & -- & $<.06$ & $<.12$ & $<.06$ & $<.06$ & $\mathrm{Be}$ & P01010 \\
\hline Boron & $\mu \mathrm{g} / \mathrm{L}$ & -- & 209 & 341 & 184 & 161 & $\mathrm{~B}$ & P01020 \\
\hline Cadmium & $\mu \mathrm{g} / \mathrm{L}$ & -- & .14 & .13 & $<.04$ & $<.04$ & $\mathrm{Cd}$ & P01025 \\
\hline Chromium & $\mu \mathrm{g} / \mathrm{L}$ & -- & E.7 & $<.8$ & 1.1 & 3.4 & $\mathrm{Cr}$ & P01030 \\
\hline Cobalt & $\mu \mathrm{g} / \mathrm{L}$ & -- & .161 & .790 & .074 & .036 & $\mathrm{Co}$ & P01035 \\
\hline Copper & $\mu \mathrm{g} / \mathrm{L}$ & -- & 6.2 & 3.7 & 1.3 & .6 & $\mathrm{Cu}$ & P01040 \\
\hline Iron & $\mu \mathrm{g} / \mathrm{L}$ & -- & 109 & $<18$ & $<18$ & 20 & $\mathrm{Fe}$ & P01046 \\
\hline Lead & $\mu \mathrm{g} / \mathrm{L}$ & -- & .58 & .23 & E.07 & $<.08$ & $\mathrm{~Pb}$ & P01049 \\
\hline Lithium & $\mu \mathrm{g} / \mathrm{L}$ & -- & 1.5 & 5.0 & 2.1 & E.6 & $\mathrm{Li}$ & P01130 \\
\hline Manganese & $\mu \mathrm{g} / \mathrm{L}$ & -- & 14.4 & 5.4 & 1.2 & .5 & Mn & P01056 \\
\hline Molybdenum & $\mu \mathrm{g} / \mathrm{L}$ & -- & .5 & 2.2 & 2.6 & 2.0 & Mo & P01060 \\
\hline Nickel & $\mu \mathrm{g} / \mathrm{L}$ & -- & 1.53 & 3.87 & .19 & .13 & $\mathrm{Ni}$ & P01065 \\
\hline Selenium & $\mu \mathrm{g} / \mathrm{L}$ & -- & $<.4$ & $<.8$ & .8 & .8 & $\mathrm{Se}$ & P01145 \\
\hline Silver & $\mu \mathrm{g} / \mathrm{L}$ & -- & $<.2$ & $<.4$ & $<.2$ & $<.2$ & $\mathrm{Ag}$ & P01075 \\
\hline Strontium & $\mu \mathrm{g} / \mathrm{L}$ & -- & 176 & 806 & 270 & 166 & $\mathrm{Sr}$ & P01080 \\
\hline Thallium & $\mu \mathrm{g} / \mathrm{L}$ & -- & $<.04$ & $<.08$ & $<.04$ & $<.04$ & $\mathrm{Tl}$ & P01057 \\
\hline Vanadium & $\mu \mathrm{g} / \mathrm{L}$ & -- & 20.3 & 33.4 & 29.8 & 25.4 & $\mathrm{~V}$ & P01085 \\
\hline Zinc & $\mu \mathrm{g} / \mathrm{L}$ & -- & 909 & 20 & 5 & 1 & $\mathrm{Zn}$ & P01090 \\
\hline Uranium & $\mu \mathrm{g} / \mathrm{L}$ & -- & $<.04$ & .62 & .17 & .14 & $\mathrm{U}$ & $\mathrm{P} 22703$ \\
\hline
\end{tabular}


Table 3. Pharmaceuticals in wastewater effluent and untreated ground water, Kihei, Hawaii, November 15-17, 2004.

[Values in micrograms per liter; detections are bold and shaded; <, not detected at the laboratory reporting level (LRL) shown; --, not applicable. Results are from USGS National Water Quality Laboratory custom lab code 9003 for analysis of pharmaceuticals in filtered water by high-performance liquid chromatography/electrospray ionization mass spectrometry (Cahill and others, 2004)]

\begin{tabular}{|c|c|c|c|c|c|}
\hline Chemical compound & $\begin{array}{c}\text { Wastewater } \\
\text { effluent }\end{array}$ & $\begin{array}{c}\text { Downgradient } \\
\text { well }\end{array}$ & $\begin{array}{c}\text { Cross-gradient } \\
\text { well }\end{array}$ & Upgradient well & Compound use \\
\hline State well number: & $6-4426.01$ & $6-4427-04$ & $6-4326-09$ & $6-4426-03$ & \\
\hline Date: & 17-Nov-2004 & 15-Nov-2004 & 15-Nov-2004 & 16-Nov-2004 & \\
\hline Time: & 1100 & 1100 & 1500 & 1100 & \\
\hline Acetaminophen & $<.036$ & $<.036$ & $<.036$ & $<.036$ & Analgesic \\
\hline Azithromycin & $<.004$ & $<.004$ & $<.004$ & $<.004$ & Antibiotic \\
\hline Caffeine & $<.016$ & $<.016$ & $<.016$ & $<.016$ & $\begin{array}{l}\text { Central nervous-system } \\
\text { stimulant }\end{array}$ \\
\hline Carbamazepine & 0.111 & 0.114 & $<.011$ & $<.011$ & $\begin{array}{l}\text { Antiepileptic, mood } \\
\text { stabilizer }\end{array}$ \\
\hline Codeine & $<.015$ & $<.015$ & $<.015$ & $<.015$ & Narcotic, analgesic \\
\hline Cotinine & 0.035 & $<.014$ & $<.014$ & $<.014$ & Nicotine metabolite \\
\hline Dehydronifedipine & $0.022^{1}$ & $0.0147^{2}$ & $<.015$ & $<.015$ & Antianginal metabolite \\
\hline Diphenhydramine & 0.129 & $<.015$ & $<.015$ & $0.0108^{3}$ & Antihistamine (Benadryl) \\
\hline Diltiazem & $<.016$ & $<.016$ & $<.016$ & $<.016$ & $\begin{array}{l}\text { Antianginal, antihyper- } \\
\text { tensive }\end{array}$ \\
\hline Erythromycin & $<.009$ & $<.009$ & $<.009$ & $<.009$ & Antibiotic \\
\hline Fluoxetine & $<.014$ & $<.014$ & $<.014$ & $<.014$ & Antidepressant \\
\hline Furosemide $^{4}$ & $<\mathrm{LRL}$ & $<\mathrm{LRL}$ & $<\mathrm{LRL}$ & $<\mathrm{LRL}$ & Oral diuretic \\
\hline Salbutamol & $<.023$ & $<.023$ & $<.023$ & $<.023$ & Antiasthmatic \\
\hline Sulfamethoxazole & $<.064$ & $<.064$ & $<.064$ & $<.064$ & Antibiotic \\
\hline Thiabendazole & $<.011$ & $<.011$ & $<.011$ & $<.011$ & $\begin{array}{l}\text { Anthelmintic (intestinal } \\
\text { wormer) }\end{array}$ \\
\hline Trimethoprim & 0.025 & $<.013$ & $<.013$ & $<.013$ & Antibiotic \\
\hline Warfarin & $<.012$ & $<.012$ & $<.012$ & $<.012$ & Anticoagulant \\
\hline
\end{tabular}

${ }^{1}$ Not a conclusive detection; present in blank, and sample concentration was not more than 10 times the blank concentration of $0.0070 \mathrm{mg} / \mathrm{L}$.

${ }^{2}$ Not a conclusive detection; present in blank, and sample concentration was not more than 10 times the blank concentration of $0.0106 \mathrm{mg} / \mathrm{L}$.

${ }^{3}$ Not a conclusive detection; present in blank, and sample concentration was not more than 10 times the blank concentration of $0.0086 \mathrm{mg} / \mathrm{L}$.

${ }^{4}$ Could not be detected under experimental conditions; LRL not determined. 
Table 4. Organic wastewater compounds in wastewater effluent and untreated ground water, Kihei, Hawaii, November 15-17, 2004.

[Values in micrograms per liter; detections are bold and shaded, <, not detected at the minimum reporting level shown; E, estimated; M, presence of material verified but not quantified; --, not applicable; Pcode, U.S. Geological Survey parameter code. Results are from USGS National Water Quality Laboratory analytical schedule 1433, "Determination of wastewater compounds by polystyrene-divinylbenzene solid-phase extraction and capillary-column gas chromatography/mass spectrometry" (Zaugg and others, 2002)]

\begin{tabular}{|c|c|c|c|c|c|c|}
\hline Chemical compound & $\begin{array}{c}\text { Wastewater } \\
\text { effluent }\end{array}$ & Downgradient well & Cross-gradient well & Upgradient well & Compound use & Pcode \\
\hline State well number: & $6-4426.01$ & $6-4427-04$ & $6-4326-09$ & $6-4426-03$ & & \\
\hline USGS site identification number: & 204411156263800 & 204423156272501 & 204334156264301 & 204456156264101 & & \\
\hline Date: & 17-Nov-2004 & 15-Nov-2004 & 15-Nov-2004 & 16-Nov-2004 & & \\
\hline Time: & 1100 & 1100 & 1500 & 1100 & & \\
\hline 1,4-Dichlorobenzene & E.2 & E.1 & $<.5$ & $<.5$ & Deodorizer & P34572 \\
\hline 1-Methylnaphthalene & $<.5$ & $<.5$ & $<.5$ & $<.5$ & PAH & P62054 \\
\hline 2,6-Dimethylnaphthalene & $<.5$ & $<.5$ & $<.5$ & $<.5$ & PAH & P62055 \\
\hline 2-Methylnaphthalene & $<.5$ & $<.5$ & $<.5$ & $<.5$ & PAH & P62056 \\
\hline 3-beta-Coprostanol & $<2$ & $<2$ & $<2$ & $<2$ & Fecal steroid & P62057 \\
\hline 3-Methyl-1H-indole & $<1$ & $<1$ & $<1$ & $<1$ & Fragrance & P62058 \\
\hline 3-tert-Butyl-4-hydroxyanisole & $<5$ & $<5$ & $<5$ & $<5$ & Antioxidant & P62059 \\
\hline 4-Cumylphenol & $<1$ & $<1$ & $<1$ & $<1$ & Nonionic detergent metabolite & P62060 \\
\hline 4-Nonylphenol & $<5$ & $<5$ & $<5$ & $<5$ & Nonionic detergent metabolite & P62085 \\
\hline 4-Octylphenol & $<1$ & $<1$ & $<1$ & $<1$ & Nonionic detergent metabolite & P62061 \\
\hline 4-tert-Octylphenol & $<1$ & $<1$ & $<1$ & $<1$ & Nonionic detergent metabolite & P62062 \\
\hline 5-Methyl-1H-benzotriazole & M & $<2$ & $<2$ & $<2$ & Anticorrosive & P62063 \\
\hline 9,10-Anthraquinone & $<.5$ & $<.5$ & $<.5$ & $<.5$ & Pesticide & P62066 \\
\hline Acetophenone & $<.5$ & $<.5$ & $<.5$ & $<.5$ & Fragrance & P62064 \\
\hline $\begin{array}{l}\text { Acetyl hexamethyl tetrahydro naphthalene } \\
\text { (AHTN) }\end{array}$ & 0.7 & $<.5$ & $<.5$ & $<.5$ & Fragrance & P62065 \\
\hline Anthracene & $<.5$ & $<.5$ & $<.5$ & $<.5$ & РAH & P34221 \\
\hline Benzo[a]pyrene & $<.5$ & $<.5$ & $<.5$ & $<.5$ & РAH & P34248 \\
\hline Benzophenone & E.1 & $<.5$ & $<.5$ & $<.5$ & Fragrance & P62067 \\
\hline beta-Sitosterol & $<2$ & $<2$ & $<2$ & $<2$ & Plant steroid & P62068 \\
\hline beta-Stigmastanol & $<2$ & $<2$ & $<2$ & $<2$ & Plant steroid & P62086 \\
\hline Bisphenol A & $<1$ & $<1$ & $<1$ & $<1$ & Plasticizer & P62069 \\
\hline Bromacil & $<.5$ & $<.5$ & $<.5$ & $<.5$ & Herbicide & P04029 \\
\hline Caffeine & $<.5$ & $<.5$ & $<.5$ & $<.5$ & Stimulant & P50305 \\
\hline Camphor & $<.5$ & $<.5$ & $<.5$ & $<.5$ & Flavorant & P62070 \\
\hline Carbaryl & $<1$ & $<1$ & $<1$ & $<1$ & Insecticide & P82680 \\
\hline Carbazole & $<.5$ & $<.5$ & $<.5$ & $<.5$ & $\mathrm{PAH}$ & P62071 \\
\hline Chlorpyrifos & $<.5$ & $<.5$ & $<.5$ & $<.5$ & Insecticide & P38933 \\
\hline Cholesterol & $<2$ & $<2$ & $<2$ & $<2$ & Plant/animal steroid & P62072 \\
\hline Cotinine & E.1800 & $<1.00$ & $<1.00$ & $<1.00$ & Nicotine metabolite & P62005 \\
\hline D-Limonene & $<.5$ & $<.5$ & $<.5$ & $<.5$ & Fungicide & P62073 \\
\hline Diazinon & $<.5$ & $<.5$ & $<.5$ & $<.5$ & Insecticide & P39572 \\
\hline 4-Nonylphenol diethoxylates (NPEO2) & $<5$ & $<5$ & $<5$ & $<5$ & Nonionic detergent metabolite & P62083 \\
\hline 4-Octylphenol diethoxylates (OPEO2) & $<1$ & $<1$ & $<1$ & $<1$ & Nonionic detergent metabolite & P61705 \\
\hline 4-Octylphenol monoethoxylates (OPEO1) & $<1$ & $<1$ & $<1$ & $<1$ & Nonionic detergent metabolite & P61706 \\
\hline Fluoranthene & $<.5$ & $<.5$ & $<.5$ & $<.5$ & $\mathrm{PAH}$ & P34377 \\
\hline
\end{tabular}


Table 4. Organic wastewater compounds in wastewater effluent and untreated ground water, Kihei, Hawaii, November 15-17, 2004-Continued.

\begin{tabular}{|c|c|c|c|c|c|c|}
\hline Chemical compound & $\begin{array}{c}\text { Wastewater } \\
\text { effluent }\end{array}$ & Downgradient well & Cross-gradient well & Upgradient well & Compound use & Pcode \\
\hline $\begin{array}{l}\text { Hexahydrohexamethyl } \\
\text { cyclopentabenzopyran }\end{array}$ & E.1 & $<.5$ & $<.5$ & $<.5$ & Fragrance & P62075 \\
\hline Indole & $<.5$ & $<.5$ & $<.5$ & $<.5$ & Pesticide inert ingredient & P62076 \\
\hline Isoborneol & $<.5$ & $<.5$ & $<.5$ & $<.5$ & Fragrance & P62077 \\
\hline Isophorone & $<.5$ & $<.5$ & $<.5$ & $<.5$ & Solvent & P34409 \\
\hline Isopropylbenzene & $<.5$ & $<.5$ & $<.5$ & $<.5$ & Solvent & P62078 \\
\hline Isoquinoline & $<.5$ & $<.5$ & $<.5$ & $<.5$ & Fragrance & P62079 \\
\hline Menthol & $<.5$ & $<.5$ & $<.5$ & $<.5$ & Flavorant & P62080 \\
\hline Metalaxyl & $<.5$ & $<.5$ & $<.5$ & $<.5$ & Pesticide & P50359 \\
\hline Methyl salicylate & $<.5$ & $<.5$ & $<.5$ & $<.5$ & Liniment & P62081 \\
\hline Metolachlor & $<.5$ & $<.5$ & $<.5$ & $<.5$ & Herbicide & P39415 \\
\hline N,N-diethyl-meta-toluamide (DEET) & E.1 & M & $<.5$ & $<.5$ & Insect repellant & P62082 \\
\hline Naphthalene & $<.5$ & $<.5$ & $<.5$ & $<.5$ & PAH & P34443 \\
\hline p-Cresol & $<1$ & $\mathbf{M}$ & $<1$ & $<1$ & Wood preservative & P62084 \\
\hline Pentachlorophenol & $<2$ & $<2$ & $<2$ & $<2$ & Pesticide & P34459 \\
\hline Phenanthrene & $<.5$ & $<.5$ & $<.5$ & $<.5$ & $\mathrm{PAH}$ & P34462 \\
\hline Phenol & $<.7$ & $<.5$ & $<.5$ & $<.5$ & Disinfectant & P34466 \\
\hline Prometon & $<.5$ & $<.5$ & $<.5$ & $<.5$ & Herbicide & P04037 \\
\hline Pyrene & $<.5$ & $<.5$ & $<.5$ & $<.5$ & $\mathrm{PAH}$ & P34470 \\
\hline Tetrachloroethene & $<.5$ & $<.5$ & $<.5$ & $<.5$ & Solvent, degreaser & P34476 \\
\hline Tribromomethane & E.7 & $<.5$ & $<.5$ & $<.5$ & Disinfection byproduct & P34288 \\
\hline Tributyl phosphate & $<.5$ & $<.5$ & $<.5$ & $<.5$ & Fire retardant & P62089 \\
\hline Triclosan & $\mathbf{M}$ & $<1$ & $<1$ & $<1$ & Antimicrobial & P62090 \\
\hline Triethyl citrate & E.1 & $<.5$ & $<.5$ & $<.5$ & Plasticizer, cosmetics & P62091 \\
\hline Triphenyl phosphate & $<.5$ & $<.5$ & $<.5$ & $<.5$ & Plasticizer & P62092 \\
\hline Tris(2-butoxyethyl) phosphate & E.3 & $<.5$ & $<.5$ & $<.5$ & Fire retardant & P62093 \\
\hline Tris(2-chloroethyl) phosphate & E.2 & $<.5$ & $<.5$ & $<.5$ & Fire retardant & P62087 \\
\hline Tris(dichloroisopropyl) phosphate & E. 2 & $<.5$ & $<.5$ & $<.5$ & Fire retardant & P62088 \\
\hline
\end{tabular}


repellant DEET, and the same nicotine metabolite (cotinine) detected in the pharmaceuticals analysis. Only two of these compounds (1,4-Dichlorobenzene and DEET) were detected in the downgradient well, plus another compound that wasn't detected in the effluent (the wood preservative $\mathrm{p}$-Cresol).

The four wastewater-related compounds detected in the downgradient well (one pharmaceutical and three organic wastewater compounds) suggest that ground water there does contain a wastewater component. However, the far fewer number of compounds in the downgradient well (4) compared to effluent (16) tends to signify that organic compounds are not particularly persistent, reliable wastewater tracers in this case. If the downgradient well does withdraw injected effluent, the absence of some compounds that were present in effluent could reflect attenuation of the compounds during subsurface flow from the injection wells. Attenuation could result as the combined result of several processes, including compound degradation, sorption to aquifer materials, and dilution by other ground water that reduces concentrations to undetectable levels. Under the alternate hypothesis for the downgradient well, its water may contain a wastewater component, but one that originates not from injected effluent but from local cesspools, septic systems, or sewer-line leaks. In this case, the well may contain pharmaceuticals or organic wastewater compounds, but only those released in the nearby vicinity and not necessarily the entire suite of compounds in effluent collected from the entire sewer district. Detection of the wood preservative $\mathrm{p}$-Cresol in the downgradient well-but not in the effluent - could be interpreted as evidence of a local wastewater source or derivation from treated lumber near the well. However, there will be a delay (probably years) between injection and arrival at the downgradient well. Municipal effluent may have contained p-Cresol in the past that is now being detected at the downgradient well, even though it was not detected in the one-time effluent sample of this study.

No pharmaceuticals or organic wastewater compounds were detected conclusively in the upgradient or cross-gradient wells. The upgradient well withdraws ground water that presumably is recharged upslope. No large wastewater sources are expected upslope, but scattered households, farm plots, or livestock could contribute nutrients and waste-related constituents. The lack of detectable wastewater indicators at the cross-gradient well suggests that it is not measurably affected by wastewater, neither from municipal injection nor from upslope sources. If it does lie within the periphery of the injection plume, then wastewater indicators have been diluted or otherwise attenuated below detectable concentrations.

\section{Nutrients}

Concentrations of dissolved nitrogen and phosphorus in treated wastewater effluent were 6 and 26 times higher than background concentrations at the upgradient well and two to three orders of magnitude higher than in seawater collected at Lahaina. However, even background concentrations in regional ground water-unaffected by wastewater-are one to two orders of magnitude higher than in seawater.

Results of nutrient analyses are listed in table 2. Discussion of nutrients here is limited to nitrogen and phosphorus, although silica and carbon also are considered major nutrients, and many other elements are minor nutrients. Nutrient species chosen for graphs and load computations are total dissolved nitrogen (TDN) and total dissolved phosphorus (TDP). These include inorganic and organic fractions (the organic fraction typically is small) but exclude particulate fractions because water samples were filtered. TDN and TDP were chosen rather than DIN (dissolved inorganic nitrogen in the form of nitrite plus nitrate) and DIP (dissolved inorganic phosphorus in the form of orthophosphate), because studies have shown that considerable fractions of the organic species are bioavailable to phytoplankton or algae or can be rendered bioavailable by microbial transformation (Benitez-Nelson, 2000; Seitzinger and others, 2002; Sedlak and Pehlivanoglu, 2004). In contrast to ground water, surface seawater in Hawaii is comparatively nutrient poor, and this is a principal reason why ground-waterborne nutrients are a matter of concern for coastal waters. Dollar and Andrews (1997) reported $0.0036 \mathrm{mg} / \mathrm{L}$ (milligrams per liter) DIN and $0.0037 \mathrm{mg} / \mathrm{L}$ DIP for a water-column sample 2 $\mathrm{m}$ above the sea bottom at $30 \mathrm{~m}$ depth off Lahaina, Maui. For comparison, background concentrations in ground water from the upgradient well were $1.17 \mathrm{mg} / \mathrm{L}$ TDN and $0.067 \mathrm{mg} / \mathrm{L}$ TDP (table 2).

A graph of nitrogen and phosphorus concentrations for the five samples (fig. 14) clearly shows the high nutrient content of wastewater effluent (at upper right). Three samples at lower left (tap water, upgradient and cross-gradient wells) are low in both nutrients, which range $0.600-1.54 \mathrm{mg} / \mathrm{L}$ for TDN and 0.059-0.106 mg/L for TDP. Wastewater effluent (at upper right) has a TDN concentration of $7.33 \mathrm{mg} / \mathrm{L}$ and a TDP concentration of $1.72 \mathrm{mg} / \mathrm{L}$, roughly 6 and 26 times the TDN and TDP at the upgradient well. Concentrations at the downgradient well are intermediate between effluent and the upgradient well. The downgradient well has about one-half as much TDN (3.49 mg/L) as effluent but only about one-ninth as much TDP $(0.191 \mathrm{mg} / \mathrm{L})$; both nutrients are about three times their concentration in the upgradient well. If the downgradient well withdraws injection-plume water, then effluent TDN concentration has been attenuated by about one-half by (1) dilution with surrounding ground water (dilution is represented by the mixing line on fig. 14), (2) sorption or degradation (such as denitrification), or (3) a combination of processes. The low dissolved-oxygen content at the downgradient well (table 2) may reflect anoxic conditions in the effluent plume that would allow denitrification. The greater proportional loss of phosphorus at the downgradient well compared to nitrogen (oneninth the TDP of effluent versus one-half for TDN) is reflected by the data point falling well below the mixing line on fig. 14 . Possible mechanisms for phosphorus loss include sorption to mineral surfaces or precipitation as a mineral phase, likely as a result of microbial processes. A complication in these interpretations is the time delay required for injected effluent to reach 


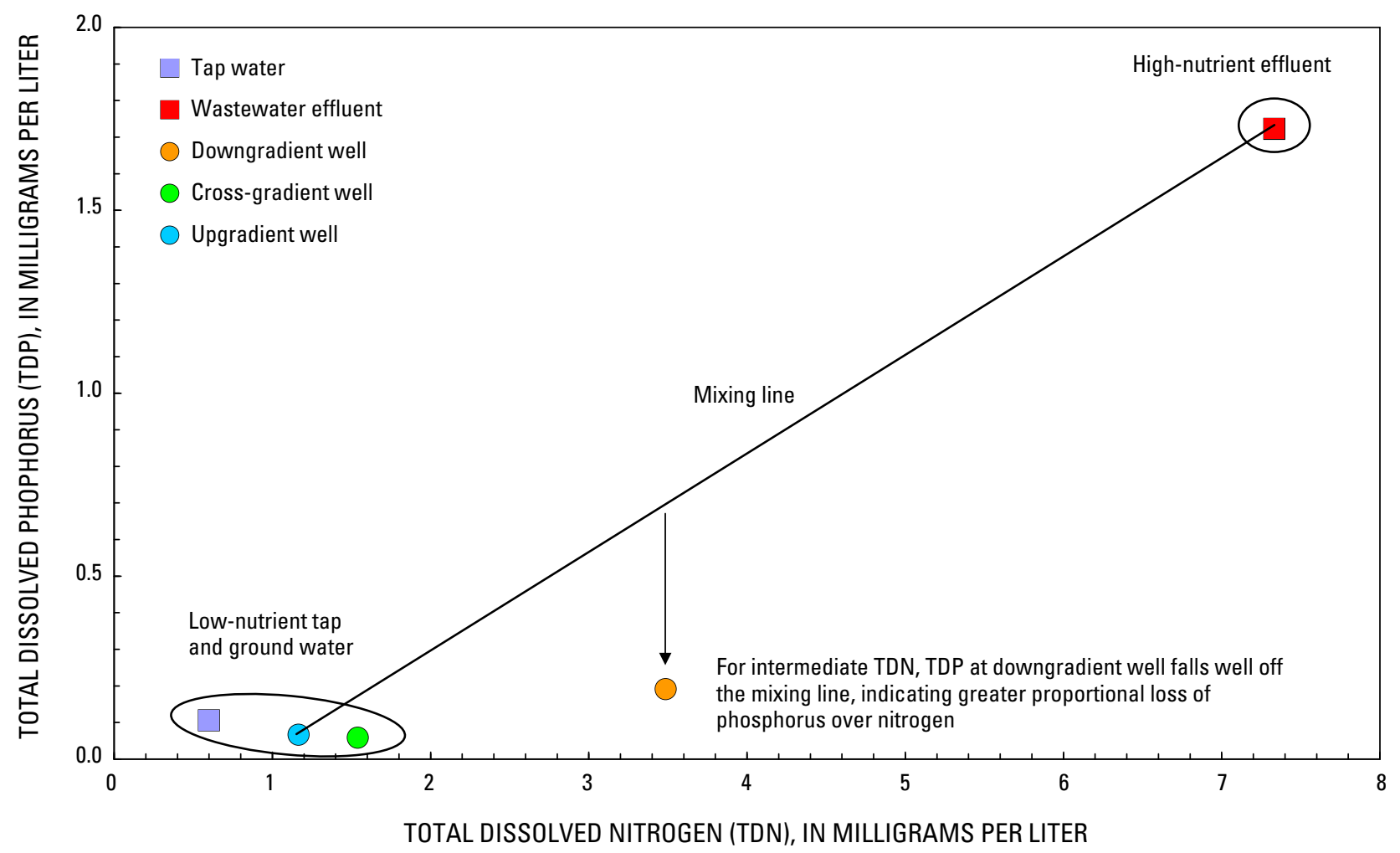

Figure 14. Graph showing dissolved nitrogen and phosphorus concentrations in tap water, wastewater effluent, and untreated ground water, Kihei, Hawaii. Wastewater effluent is much higher in nutrients than imported tap water and local ground water from the upgradient and cross-gradient wells. Nutrient concentrations at the downgradient well are intermediate between wastewater and the other waters.

the downgradient well, potentially several years. That is, the effluent sample of November 2005 may not be adequately representative of effluent that was injected several years ago and has since evolved to the composition of the November 2005 sample from the downgradient well.

\section{Stable Isotopes}

Stable isotopes of nitrogen and boron were found to be good wastewater tracers in the Kihei area. Oxygen and hydrogen isotopes in the water molecule itself were good tracers of public-supply water imported from the Iao area on the north coast of west Maui and of wastewater derived from the imported supply water. Stable isotopes can be used in combination to trace wastewater and imported supply water through the Kihei hydrologic system, whether originating from injection or other wastewater disposal, from landscape irrigation, or from leaks in water-supply or reclaimed-water distribution pipelines or sewer collection lines.
Isotopes are atoms of a given element that have a constant number of protons in the atomic nucleus but different numbers of neutrons (their atomic weights differ accordingly). Stable isotopes do not decay like radioactive isotopes but they do partition - or fractionate-during physical and chemical processes such as evaporation and condensation, nitrification and denitrification, biologic uptake, mineral dissolution or precipitation, and sorption on mineral surfaces. Isotopic composition is expressed as a ratio of two isotopes, for example ${ }^{18} \mathrm{O} /{ }^{16} \mathrm{O}$, ${ }^{2} \mathrm{H} /{ }^{1} \mathrm{H},{ }^{15} \mathrm{~N} /{ }^{14} \mathrm{~N},{ }^{11} \mathrm{~B} /{ }^{10} \mathrm{~B}$, and ${ }^{87} \mathrm{Sr} /{ }^{86} \mathrm{Sr}$ for oxygen, hydrogen, nitrogen, boron, and strontium, respectively (table 2). The numbers signify the number of neutrons in the atomic nucleus, and each ratio expresses the proportion of a heavier isotope to a lighter isotope. Notation is condensed further to "delta notation" as $\delta^{18} \mathrm{O}, \delta^{2} \mathrm{H}, \delta^{15} \mathrm{~N}$, and $\delta^{11} \mathrm{~B}$ and which are read as "delta oxygen-18" and so on (strontium is simply reported as an absolute ratio). In delta notation, the isotopic ratio of a sample has been normalized against the isotopic ratio of a reference standard (Clark and Fritz, 1997). Applicable standards for these isotopes are "VSMOW" (Vienna Standard Mean Ocean Water) for $\mathrm{O}$ and $\mathrm{H}$, "AIR" (atmospheric nitrogen) for $\mathrm{N}$, and 
"NBS-951" for B. Once reduced to delta notation, isotopic composition can be viewed simply as an index or scale: larger or more positive values indicate a heavier isotopic mixture (greater proportion of the heavy isotope), and smaller or more negative values indicate a lighter isotopic mixture. Formulas and further discussion can be found in various texts, such as Clark and Fritz (1997) and Kendall and McDonnell (1998). Interpretation of stable isotopes in this study is quite simple, dealing mainly with clustering and separation of samples on isotope cross-plots.

\section{Hydrogen and Oxygen Isotopes in Water}

Hydrogen and oxygen isotope compositions in water (table 2) are characteristic of the water molecule, $\mathrm{H}_{2} \mathrm{O}$. These compositions can be notated as $\delta^{2} \mathrm{H}_{\text {water }}$ and $\delta^{18} \mathrm{O}_{\text {water }}$ or as $\delta^{2} \mathrm{H}_{\mathrm{H} 2 \mathrm{O}}$ and $\delta^{18} \mathrm{O}_{\mathrm{H} 2 \mathrm{O}}$ and are often referred to simply as "deuterium and oxygen isotopes" $\left({ }^{2} \mathrm{H} /{ }^{1} \mathrm{H}\right.$ is a ratio of deuterium to protium).
On a cross-plot of oxygen and hydrogen isotopes (fig. 15) tap water and wastewater effluent cluster together in the upper right corner (isotopically heavy), whereas the upgradient and cross-gradient wells cluster at lower left (isotopically light). The downgradient well is intermediate but closer to tap water and effluent than to the other wells. The extreme clustering is a fortuitous result of importing tap water from Iao, where isotopically heavy trade-wind precipitation prevails. The light isotopic composition at Kihei is consistent with high-convective storm precipitation that dominates dry, rain-shadow locales (Scholl and others, 1995; Charles D. Hunt, Jr., U.S. Geological Survey, written commun., 2005). The "local meteoric line" on figure 15 was derived from rain collectors along a transect from shore to mountain summit north of Kihei (Scholl and others, 2002). The fact that all samples lie on or near the meteoric line is consistent with their isotopic compositions being determined mainly during condensation from cloud vapor. The local recharge samples (upgradient and cross-gradient wells) are displaced slightly off the meteoric line in a direction consistent with evaporation. This suggests

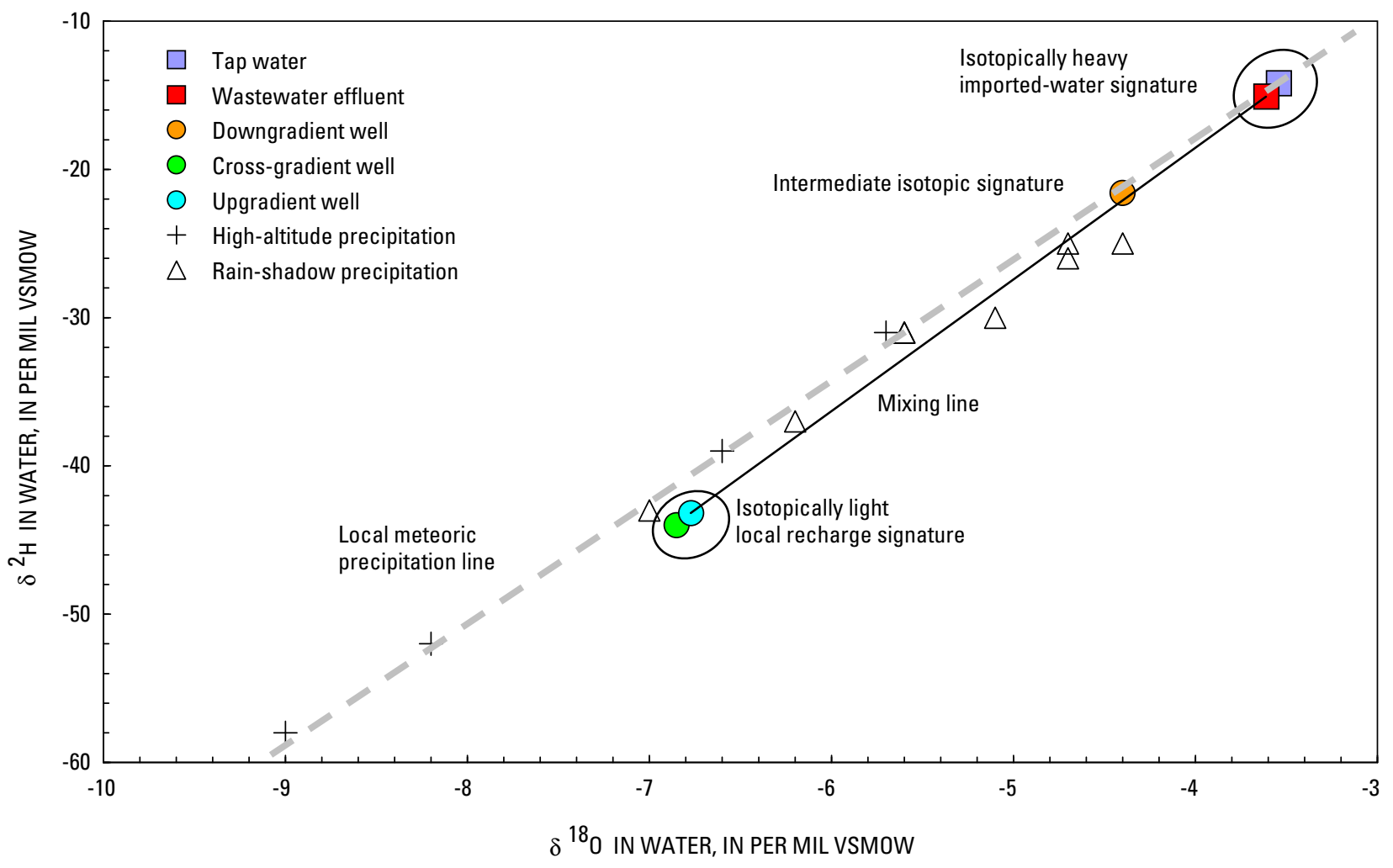

Figure 15. Graph showing oxygen and hydrogen stable-isotope compositions in tap water, wastewater effluent, and untreated ground water, Kihei, Hawaii. The isotopic composition of imported tap water is distinctly heavier than that of local ground water from the upgradient and cross-gradient wells; this signature is modified little during use and treatment and persists in wastewater. The downgradient well has an intermediate composition that is closer to tap water and wastewater than to local ground water. VSMOW (Vienna Standard Mean Ocean Water) is a reference standard that is used to express isotopic compositions. (Precipitation data and meteoric line from Scholl and others, 2002.) 
that precipitation undergoes more evaporation before becoming recharge in the drier Kihei area than in the wetter Iao area (the imported tap water), which is an expected finding.

The heavy isotopic signature of imported tap water is little modified through use and treatment cycles and persists in the wastewater effluent. Thus, tap water and wastewater can be traced through the hydrologic system at Kihei by this distinctly heavy signature-whether originating from injection or other disposal (cesspools and septic systems); from landscape irrigation with tap water or reclaimed wastewater; or from leaks in water, sewer, or reclaimed-water pipelines. The isotopic signature of irrigation-return recharge may be modified somewhat by evaporation but should still be distinguishable from local ground water. Wastewater can't be distinguished from tap water using oxygen and hydrogen isotopes, but can be discriminated using nitrogen and boron isotopes, as shown in the next two sections of this report.

A plausible interpretation for the downgradient well sample in figure 15 is that it is a mixture of imported water (effluent or tap) and local ground water. Proportional mixing calculations using $\delta^{2} \mathrm{H}$ and $\delta^{18} \mathrm{O}$ isotopic compositions suggest that the downgradient well contains about three-fourths effluent and one-fourth local ground water (the effluent proportion was 77 percent for $\delta^{2} \mathrm{H}$ and 72 percent for $\delta^{18} \mathrm{O}$ ). These simple binary mixing calculations ignore small fractions of seawater that are present (3.9 percent seawater in the downgradient well, 2.0 percent at the upgradient well, and 1.0 percent in the effluent), but Scholl and others (1995) reported negligible isotopic variations over salinity ranges of 3-5 percent and 11-15 percent at two coastal springs on Hawaii Island.

Another interpretation that can't be ruled out is that the downgradient well withdraws local recharge having the heavy isotopic composition of low-elevation precipitation (the rightmost triangle on fig. 15). Note that waters from the upgradient and cross-gradient wells were cold (table 2) and had isotopic compositions similar to the lightest rain-shadow precipitation sample (left-most triangle on fig. 15) at about 6,000 feet above sea level, even though the wells lie at much lower elevations. This suggests that water withdrawn at those wells infiltrated far upslope where it is cooler and wetter. The downgradient well also might be expected to withdraw this upland ground water as it flows through the lowlands on its way to the shore, even though the well is screened in sediments and not in the volcanic-rock aquifer. Instead, the warm temperature (table 2) and heavy isotopic composition at the downgradient well indicate that its water differs markedly from the upland water, although one can't distinguish whether the difference originates from warm, low-altitude recharge or from warm wastewater effluent. Additional tracers are required to make this distinction, such as the nitrogen isotopes discussed in the next section.

\section{Nitrogen and Oxygen Isotopes in Dissolved Nitrate}

Nitrogen and oxygen isotope compositions in dissolved nitrate (table 2) are determined by the nitrogen and oxygen atoms that make up the nitrate ion $\mathrm{NO}_{3}{ }^{-}$and can be notated as $\delta^{15} \mathrm{~N}_{\text {nitrate }}$ and $\delta^{18} \mathrm{O}_{\text {nitrate }}$ or as $\delta^{15} \mathrm{~N}_{\mathrm{NO} 3}$ and $\delta^{18} \mathrm{O}_{\mathrm{NO} 3}$. In this case, the oxygen isotope composition is not that of the water molecule but of the nitrate ion dissolved in the water.

As in the prior isotope plot, Kihei data break into wellseparated clusters on a plot of nitrogen and oxygen isotopes in dissolved nitrate (fig. 16). In this case, tap water and the upgradient and cross-gradient wells cluster together at lower left, wastewater effluent plots up and to the right of that cluster, and the downgradient well is at the extreme upper right. A plausible explanation for the light cluster (tap water, upgradient and cross-gradient wells) is that it reflects a "soil" or "background" nitrogen signature (the isotopic composition picked up by recharge through soil, perhaps largely in forests). Wastewater has a heavier composition originating from animal waste, and bacteria further enrich the effluent in heavy isotopes by preferentially metabolizing light isotopes during wastewater treatment (Jordan and others, 1997). Isotopic composition is heaviest of all in the downgradient well, and the trend on figure 16 is consistent with denitrification, whereby bacteria transform wastewater nitrate to nitrogen gas $\left(\mathrm{N}_{2}\right)$, which escapes to the atmosphere. This occurs under anoxic conditions, which can be inferred from the low dissolved-oxygen content at the downgradient well (table 2). Denitrification also would help explain the reduction in TDN at the downgradient well to one-half the effluent concentration (fig. 14) despite isotopic evidence of only a one-fourth dilution by local ground water (fig. 15). Altogether, results indicate a substantial wastewater component at the downgradient well, most likely from injected municipal effluent. A local wastewater source in the vicinity still cannot be ruled out, but nearby cesspools or sewer leaks might be expected to contribute more pharmaceuticals and organic wastewater compounds than were detected at the downgradient well (tables 2 and 3). Detection of only a few compounds is more consistent with removal of compounds during municipal treatment, followed by further compound attenuation over a long travel path in the aquifer.

The combination of $\delta^{15} \mathrm{~N}$ and $\delta^{18} \mathrm{O}$ in dissolved nitrate appear to be one of the best wastewater indicators in this study, distinctly discriminating wastewater nitrate from background (soil) nitrate originating in the upland watershed. Kihei data fit well into established classifications of nitrogen sources, such as that shown by Kendall and McDonnell (1998; modified here as figure 17; see also Clark and Fritz, 1997). Although wastewater and background nitrate end members were characterized by sampling at Kihei, the isotopic composition of fertilizer nitrate in the Kihei urban strip was not. Fertilizer nitrate is isotopically lighter than animal-waste nitrate and would fall nearer the soil composition on figure 17. This isotopic approach using $\delta^{15} \mathrm{~N}$ and $\delta^{18} \mathrm{O}$ could be useful for 


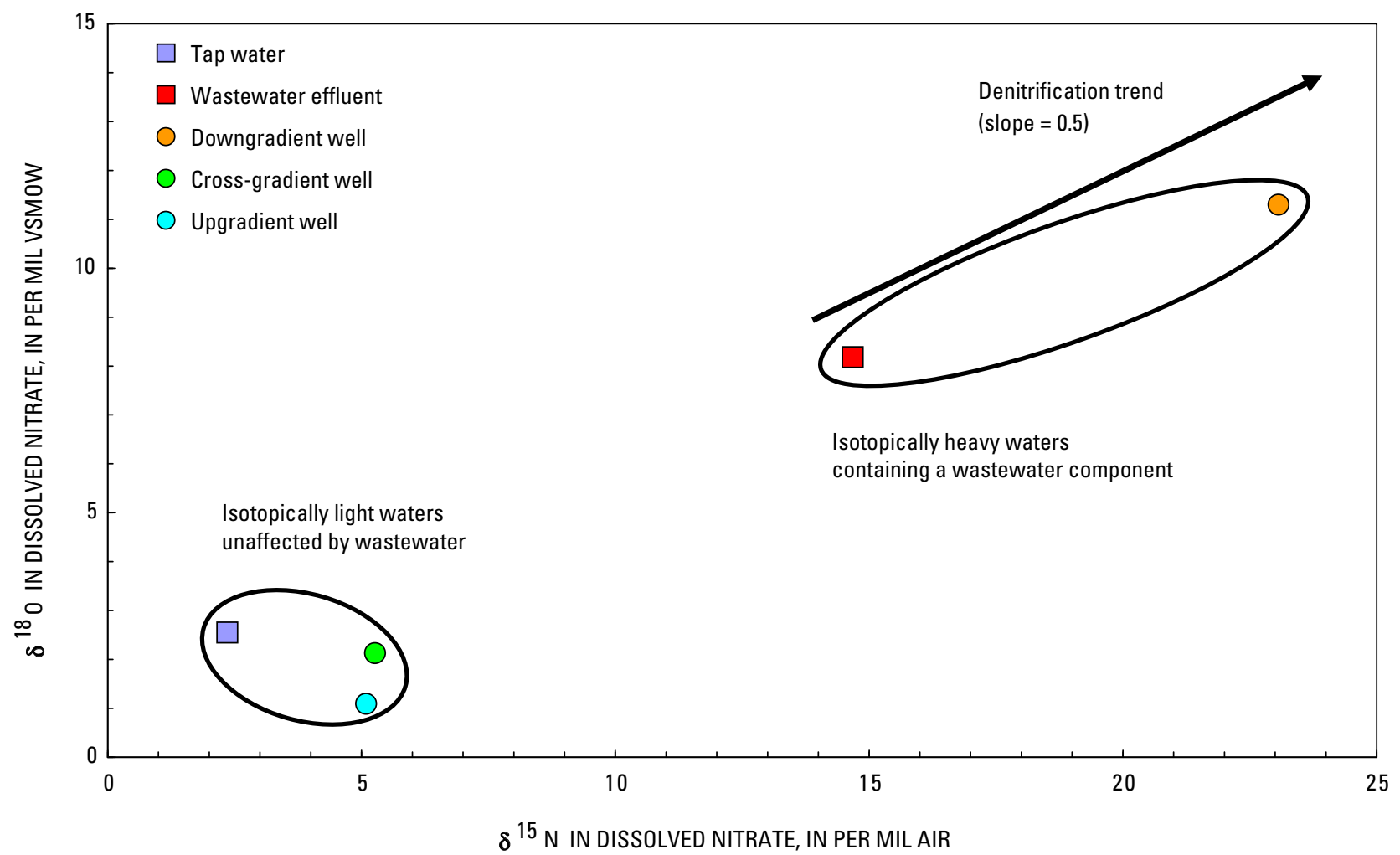

Figure 16. Graph showing nitrogen and oxygen stable-isotope compositions of dissolved nitrate in tap water, wastewater effluent, and untreated ground water, Kihei, Hawaii. The isotopic composition of wastewater nitrate is distinctly heavier than that of nitrate in imported tap water and in local ground water from the upgradient and cross-gradient wells. The downgradient well has the heaviest composition, one that is consistent with denitrification from a wastewater starting point. VSMOW (Vienna Standard Mean Ocean Water) and AIR (atmospheric air) are reference standards that are used to express isotopic compositions.

further nitrogen source tracking or source attribution at Kihei and elsewhere in Hawaii.

\section{Boron Isotopes}

The stable-isotope composition of dissolved boron was measured and is notated as $\delta^{11} \mathrm{~B}$ (table 2). Plotted against the same nitrogen isotope axis as in the previous plot, $\delta^{11} \mathrm{~B}$ provides further confirmation of a wastewater component (fig. 18). Tap water and the upgradient and cross-gradient wells cluster at upper left, whereas wastewater effluent and the downgradient well cluster to the lower right, having light $\delta^{11} \mathrm{~B}$ and heavy $\delta^{15} \mathrm{~N}$ compositions.

The light boron composition of wastewater is likely imparted by laundry detergents that contain sodium borate as a fabric whitening agent (Vengosh and others, 1994; Widory and others, 2005). Seawater $\delta^{11} \mathrm{~B}$ is about 40 per mil and compositions derived from rock weathering and laundry detergents are about zero per mil (Thomas D. Bullen, USGS Boron Isotope
Lab, oral commun., 2005). Boron compositions in tap water and the upgradient and cross-gradient wells are much closer to 40 than to zero, suggesting that boron in these ground waters comes mainly from sea spray and precipitation around sea-salt condensation nuclei rather than from rock weathering. Slight enrichment in ground water over seawater (45-50 versus 40 per mil) likely results from preferential sorption of the light isotope ${ }^{10} \mathrm{~B}$ during infiltration through clay-rich soil (Kendall and McDonnell, 1998; Thomas D. Bullen, USGS Boron Isotope Lab, oral commun., 2005). The heavier $\delta^{11} \mathrm{~B}$ value of imported tap water (about 48 per mil) apparently is reduced to about 32 per mil in wastewater effluent through the addition of laundry detergents in the water-use cycle. The fact that water withdrawn from the downgradient well also has this lighter $\delta^{11} \mathrm{~B}$ composition indicates a substantial wastewater component and supports the hypothesis that the downgradient well lies within the injected effluent plume. 


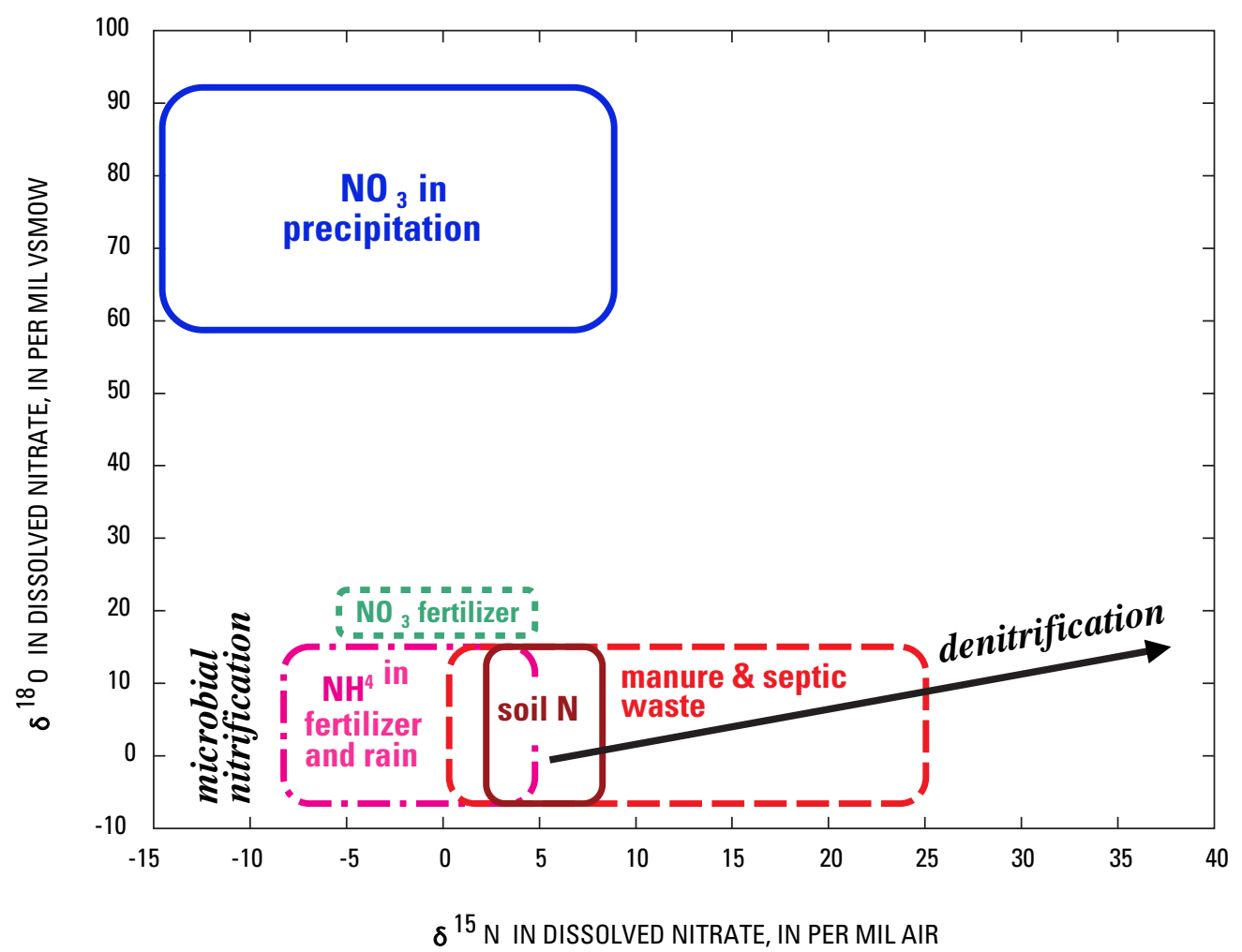

Figure 17. Graph showing nitrate source classification based on nitrogen and oxygen stableisotope compositions in dissolved nitrate. Colored lines bound istotopic compositions of various nitrate sources and are based on results reported in many studies. Results from Kihei water samples fall within the soil and septic fields of this classification. VSMOW (Vienna Standard Mean Ocean Water) and AIR (atmospheric air) are reference standards that are used to express isotopic compositions. (Updated from Kendall and McDonnell, 1998, by Carol Kendall, USGS, written commun., 2006.)

\section{Water-Type Classification Using Nutrient and Stable-Isotope Signatures}

Nutrient and stable-isotope compositions can be combined in a classification of distinct water types at Kihei (table 5). This approach is independent of the use of pharmaceuticals and organic wastewater compounds as wastewater-specific indicators (tables 2 and 3). Waters sampled in this study are divided into three types (table $5 B$ ). Type 1 water is ground water recharged locally in the Kihei uplands, as sampled by the upgradient and cross-gradient wells. Type 2 water is imported public-supply tap water, which originated as ground water recharged on the wetter north side of the island. Type 3 water contains a wastewater component and is represented by Kihei wastewater effluent and the downgradient well. Chemical signatures for these waters were derived in table $5 B$ by ranking the various nutrient concentrations and stable-isotope compositions in table $5 A$ simply as low, medium, or high. The rankings are arbitrary and imprecise, but the classification provides a useful and concise summary of much of the preceding technical discussion.
Type 1 local ground water is low in all measures except $\delta^{11} \mathrm{~B}$ and $\delta^{87} \mathrm{Sr}$, where it has high and medium values, respectively. Type 2 imported water is similar to type 1 but is distinguishable by high $\delta^{2} \mathrm{H}$ and $\delta^{18} \mathrm{O}$ values in water and a low $\delta^{87} \mathrm{Sr}$ value. Type 3 waters are wastewater or wastewater derived; they have high or medium values for most measures (most notably $\delta^{15} \mathrm{~N}$ ) but low values for $\delta^{11} \mathrm{~B}$, in contrast to type 1 and type 2 waters. These relations are summarized to provide "diagnostic signatures" at the bottom of table 5b. Type 1 and 2 waters are low in nutrients but can be distinguished from each other by their opposing values of $\delta^{2} \mathrm{H}_{\text {water }}$ and $\delta^{18} \mathrm{O}_{\text {water }}$. Type 3 wastewater can be distinguished from type 1 and 2 waters by higher nutrient concentrations, but most conclusively by heavier $\delta^{15} \mathrm{~N}$ and lighter $\delta^{11} \mathrm{~B}$ values.

The water-chemistry signatures in table 5 represent multiple lines of evidence for tracing regional ground water and injected wastewater from land to sea. Under fortuitous conditions, these signatures might be identifiable where ground water discharges along the beach or at the sea bottom close to shore. Nutrients will be subject to further loss, gain, or transformation as ground water seeps through coastal sediments, so 
Table 5. Water-type classification derived from nutrient and stable-isotope compositions, Kihei, Hawaii, November 15-17, 2004.

$\left[\mathrm{mg} / \mathrm{L}\right.$, milligrams per liter; $\mathrm{mg} / \mathrm{L}$, micrograms per liter; $\delta$, delta notation for isotopic compositions; per mil, parts per thousand; $\mathrm{NO}_{3}$, nitrate; $\mathrm{NH}_{4}$, ammonium; --, not analyzed]

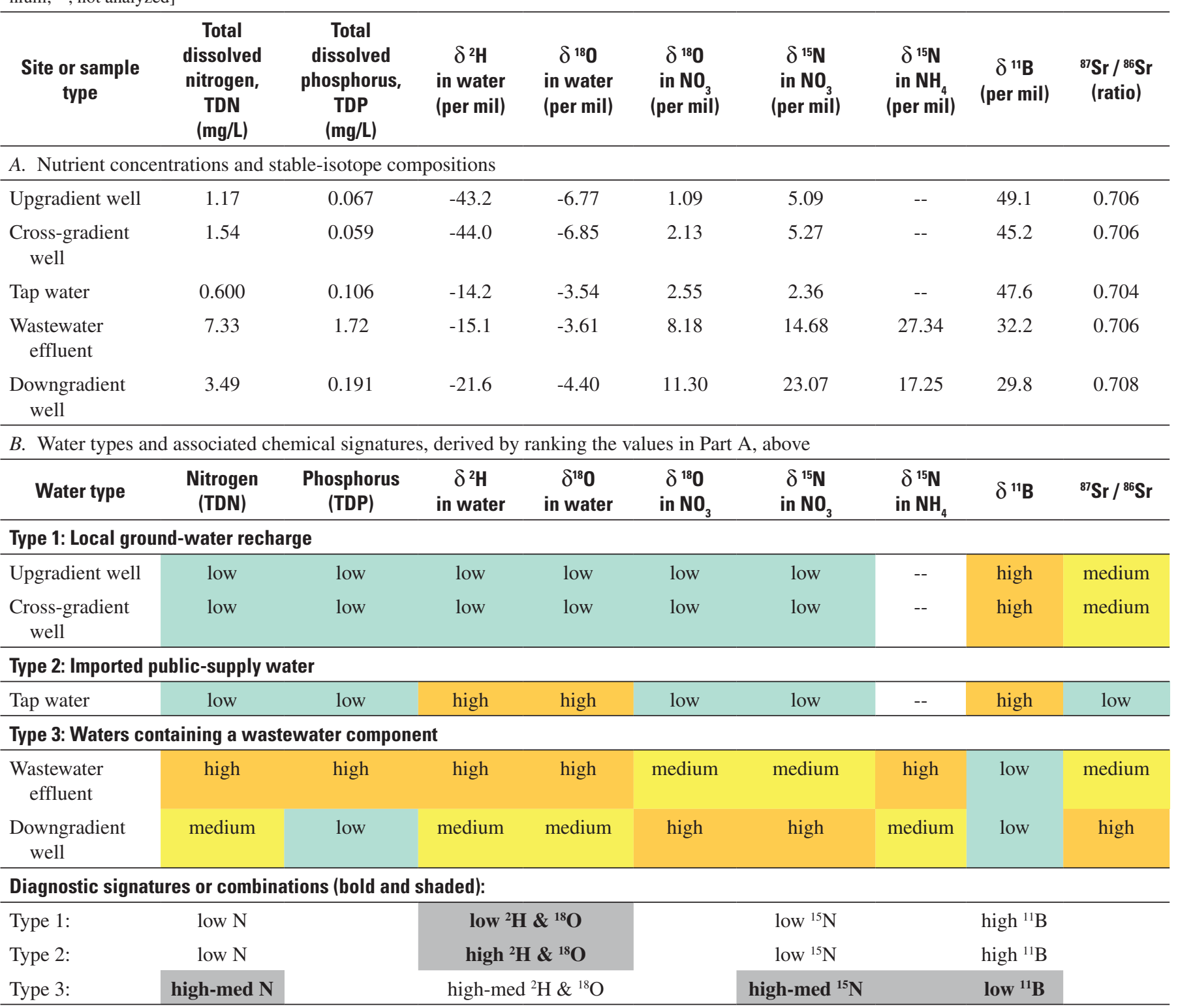

nutrient concentrations alone will not be diagnostic of terrestrial nutrients. Nitrogen and oxygen isotopes in dissolved nitrate also may be modified by nitrogen transformations, but the heavy $\delta^{15} \mathrm{~N}$ signature of wastewater is not likely to be lost entirely. The light $\delta^{11} \mathrm{~B}$ signature and heavy $\delta^{2} \mathrm{H}_{\text {water }}$ and $\delta^{18} \mathrm{O}_{\text {water }}$ signatures of wastewater probably will be little modified and should remain diagnostic. Leaking water pipes should be distinguishable from leaking sewer pipes by $\delta^{15} \mathrm{~N}$ and $\delta^{11} \mathrm{~B}$ despite having similar $\delta^{2} \mathrm{H}_{\text {water }}$ and $\delta^{18} \mathrm{O}_{\text {water }}$ compositions.

\section{Limitations of the Water-Chemistry Sampling}

A main limitation of the water sampling program is that very few samples were obtained. The number of samples seems to have been sufficient to identify several principal water types at Kihei, but other important types were not characterized, such as urban ground water subject to landscape fertilizers and distributed wastewater sources (cesspools, septic systems, sewer leaks). Furthermore, although one sample appears to be from within the injected wastewater plume (the 


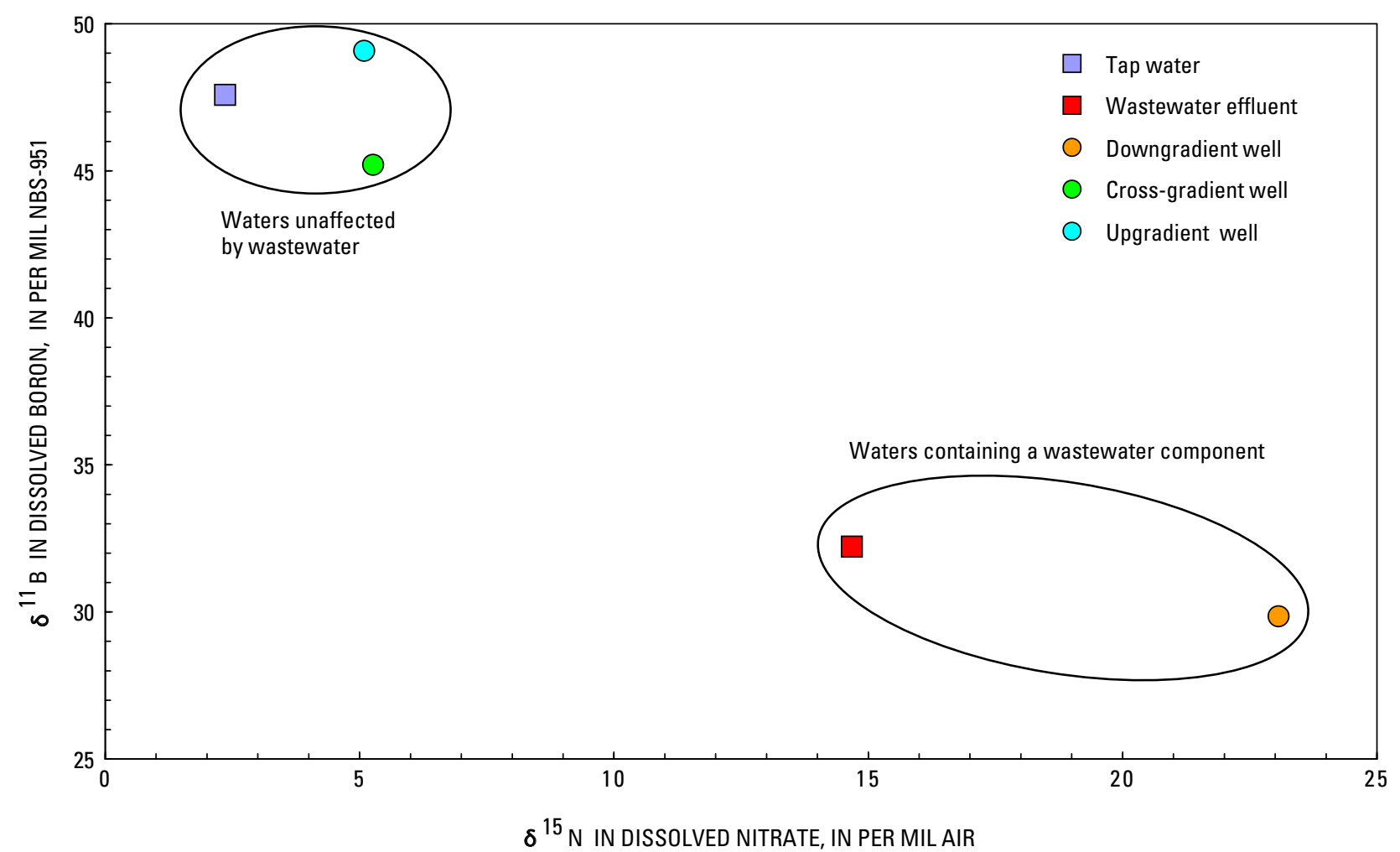

Figure 18. Graph showing boron and nitrogen stable-isotope compositions in tap water, wastewater effluent, and untreated ground water, Kihei, Hawaii. Boron-isotope composition is distinctly lighter in wastewater and the downgradient well than in imported tap water and in local ground water from the upgradient and cross-gradient wells. NBS-951 (National Bureau of Standards) and AIR (atmospheric air) are reference standards that are used to express isotopic compositions.

downgradient well), more wells or beach samples would be required to define the extent of the plume with a field-mapping approach. Finally, this one-time sampling did not characterize temporal variations in chemistry. For example, it is unknown how representative the well samples are of ground-water chemistry from day to day, through seasons, or over several decades. However, a review of treatment-plant records showed that nitrogen and phosphorus concentrations in treated wastewater effluent have remained fairly stable for at least several years.

\section{Terrestrial Ground-Water and Nutrient Fluxes}

Ground-water and nutrient fluxes (table 6 and fig. 19) were estimated by multiplying sampled nutrient concentrations by recharge and wastewater injection rates. The fluxes are highly approximate first-order estimates, are based on simplifying assumptions, and are mainly an attempt to view the injected nutrient load within a simple and understand- able framework. Regional ground-water flow was estimated to be $22.6 \mathrm{Mgal} / \mathrm{d}$ within the study area, or $2.825 \mathrm{Mgal} / \mathrm{d}$ per coastline mile, assuming flow is evenly distributed along 8.0 miles of coast. Another $3.0 \mathrm{Mgal} / \mathrm{d}$ is added by injection of reclaimed wastewater; this is equivalent to 13 percent of the regional flow and is assumed to largely displace the regional flow, although there will be some mixing of effluent and regional freshwater at the lateral margins of the injection plume. Background nutrient load in the regional flow was estimated at $100 \mathrm{~kg} / \mathrm{d}$ (kilograms per day) of nitrogen and $5.7 \mathrm{~kg} / \mathrm{d}$ of phosphorus. Wastewater injection adds $83 \mathrm{~kg} / \mathrm{d}$ nitrogen and $20 \mathrm{~kg} / \mathrm{d}$ phosphorus - nearly as much nitrogen and 3.5 times as much phosphorus as the background load for the entire study area. Not all the injected load reaches coastal waters, however. Assuming the downgradient well is representative of the effluent plume, then the wastewater nutrient load is naturally attenuated in the aquifer to one-half the injected load for nitrogen and one-ninth for phosphorus. Nutrients may be further attenuated between downgradient well and shore, or in coastal sediments, though this would need to be assessed using additional wells and by ocean-bottom and beach porewater sampling. 
Table 6. Estimated ground-water and nutrient fluxes, Kihei, Hawaii, November 2004.

[Mgal/d, million gallons per day; land use from digital map of land-use districts (State of Hawaii, 2004a)]

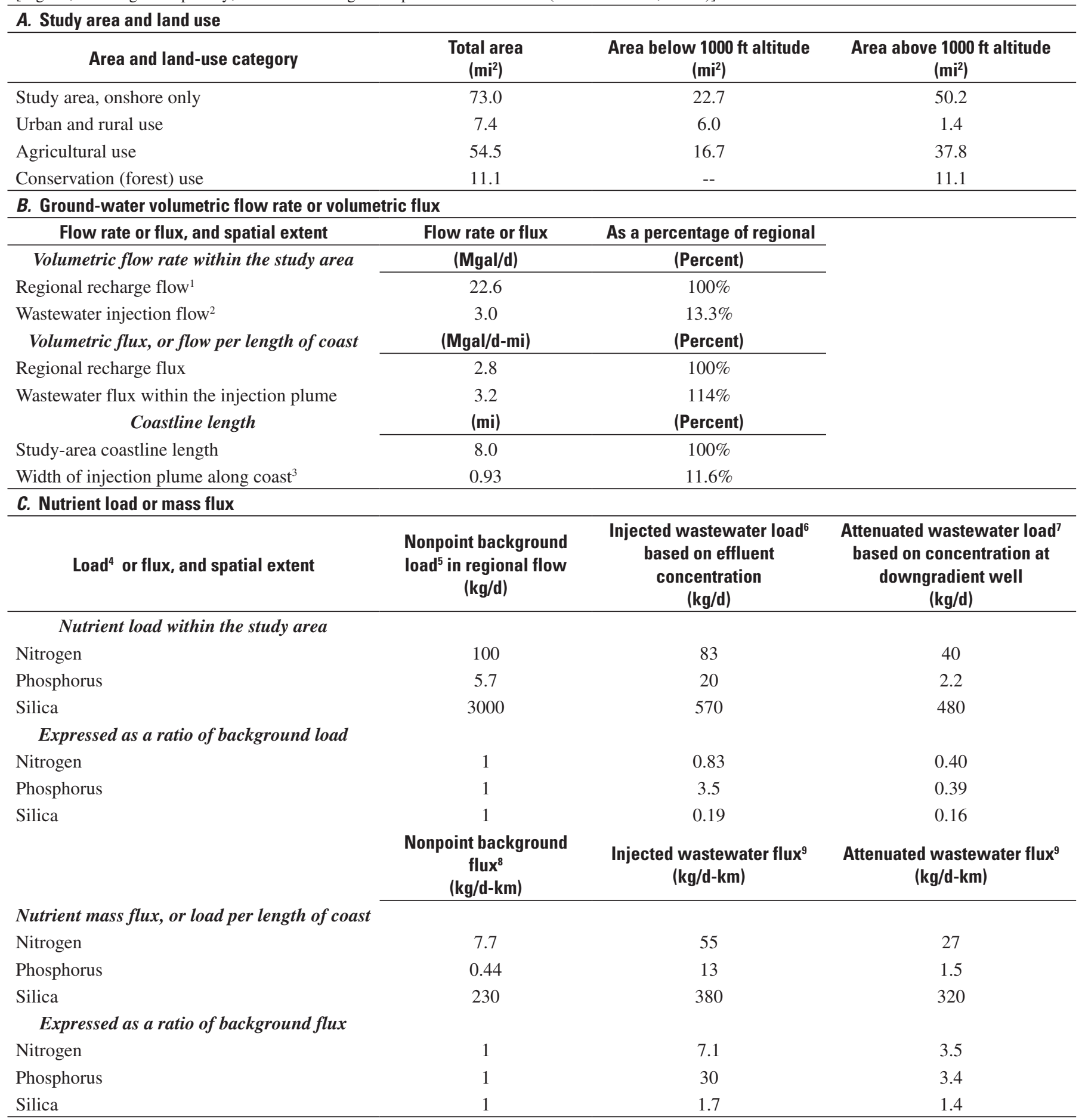

${ }^{1}$ Recharge computed by summing the GIS (geographic information system) water budget of Shade (1999).

${ }^{2}$ Injection rate is the average for the most recent reporting year September 2003 through August 2004.

${ }^{3}$ Width of injected wastewater effluent plume along the coast is from model simulation, this report.

${ }^{4}$ Nutrient load is the product of ground-water flow rate multiplied by nutrient concentration (TDN and TDP for nitrogen and phosphorus).

${ }^{5}$ Regional recharge rate multiplied by concentration in the upgradient well, which is presumed to represent background concentration.

${ }^{6}$ Injection rate multiplied by concentration in the injected wastewater effluent.

${ }^{7}$ Injection rate multiplied by concentration in the downgradient well, which is presumed to reflect nutrient attenuation in the effluent plume.

${ }^{8}$ Background load divided by the coastline length of the entire study area, 8.0 miles (13 km).

${ }^{9}$ Wastewater load divided by the width of the modeled wastewater effluent plume along the coast, 0.93 miles (1.5 km). 

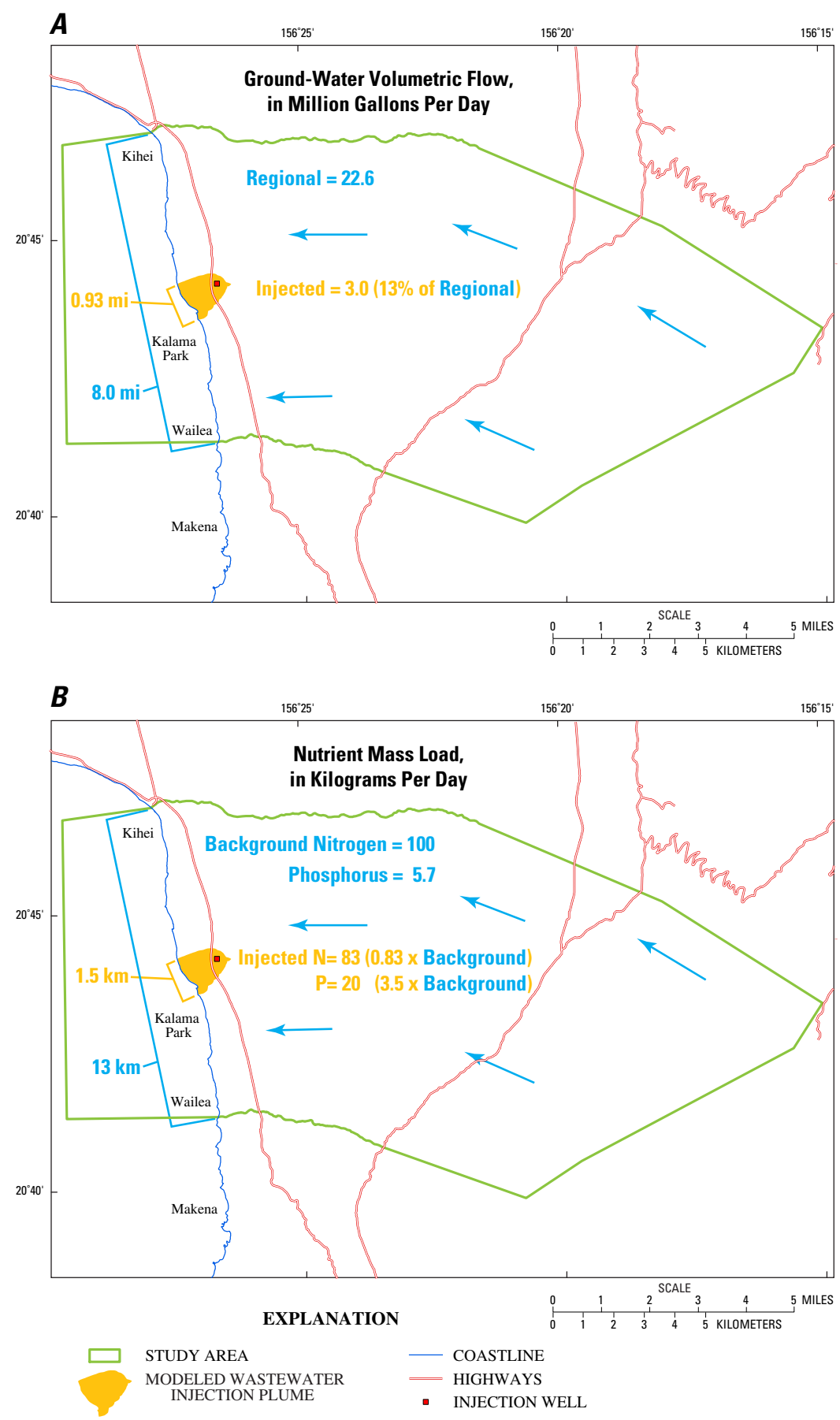

Figure 19. Maps showing estimated ground-water and nutrient fluxes, Kihei, Hawaii. Blue lettering denotes regional fluxes and yellow denotes injected fluxes. $A$, Recharge-driven regional flow (blue arrows) discharges along 8.0 miles of coast; injected effluent discharges from a 0.93-mile-wide plume and is 13 percent of regional flow. $B$, Injected nitrogen and phosphorus loads are 0.83 and 3.5 times background load in regional flow. $C$, Injected nitrogen and phosphorus fluxes (load per length of coast) are 7.1 and 30 times background flux. $D$, Natural attenuation in the aquifer reduces injected nitrogen and phosphorus fluxes to 3.5 and 3.4 times background by the time effluent reaches the downgradient well. 

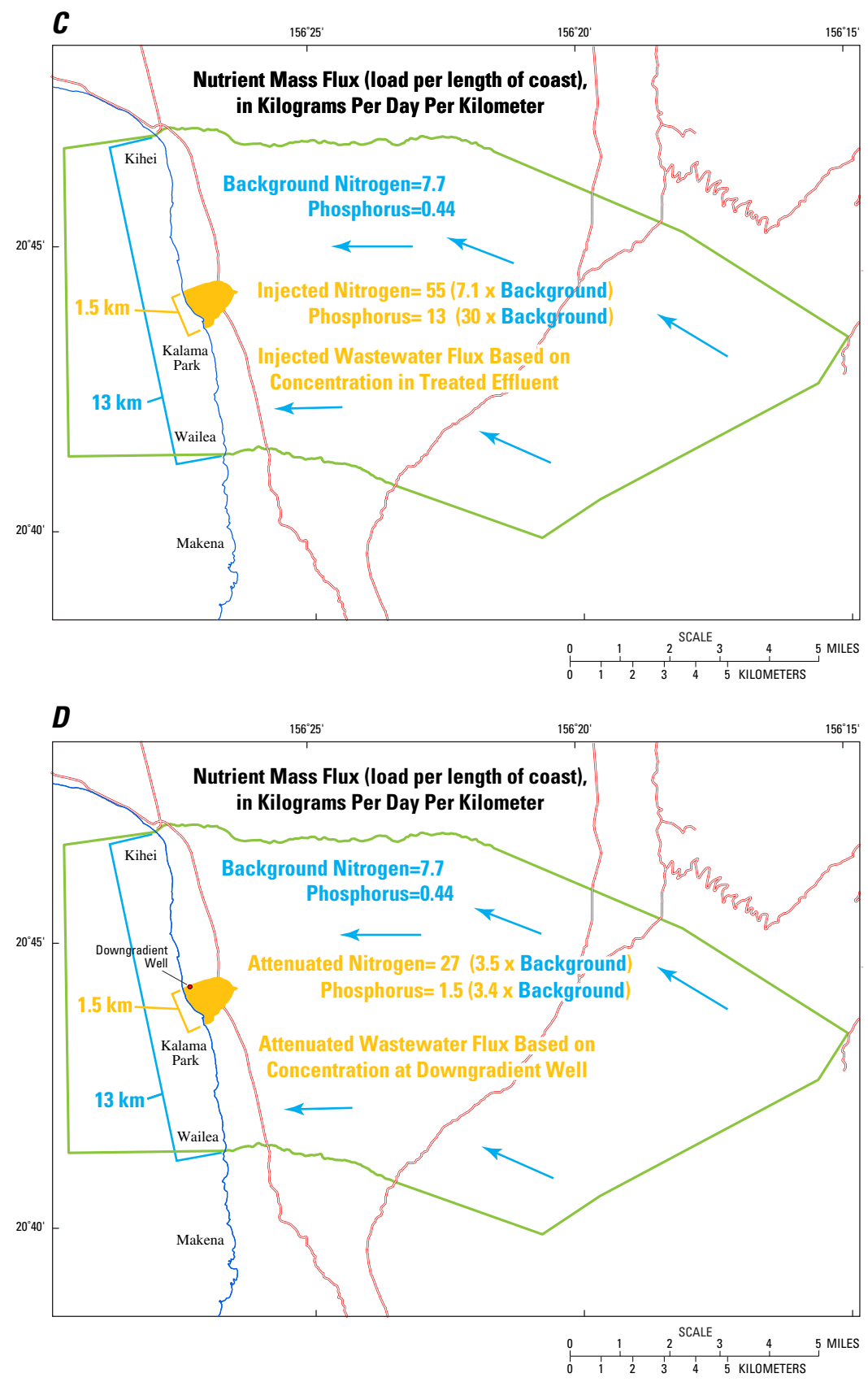

Figure 19.-Continued. 


\section{Ground-Water Fluxes}

Two principal ground-water fluxes are of interest in this study: (1) regional flow of ground water from mountains to ocean, and (2) point-source injection of wastewater effluent at the Maui County Wastewater Reclamation Facility. Each can be expressed as a simple volumetric flow rate (volume per unit time), and for comparability each can be divided by an appropriate length of coastline and expressed as a volumetric flux (volume per unit time per unit length of coast) Although by strict definition flux is flow per unit area, coastal length is a more relevant divisor for quantifying ground-water discharge to coastal waters.

Regional ground-water flow was estimated to be 22.6 $\mathrm{Mgal} / \mathrm{d}$ within the study area, a volumetric flux of $2.825 \mathrm{Mgal} /$ $\mathrm{d}$ per coastline mile along the 8.0-mile coast (table $6 B$ and fig. 19A). This estimate was obtained by summing the digital recharge map (fig. 11; Shade, 1999) over the 73 square-mile study area and equating recharge with ground-water flow and discharge, neglecting ground-water withdrawals as a simplification. An average of $1.6 \mathrm{Mgal} / \mathrm{d}$ (1986-2000) is withdrawn for landscape irrigation at Wailea resort at the south end of the study area, but some fraction of that water will reinfiltrate to ground water, as will septic flows and leaks from water and sewer lines.

Injection at Kihei Wastewater Reclamation Facility averaged $3.0 \mathrm{Mgal} / \mathrm{d}$ for the reporting year just prior to field investigations (September 2003 through August 2004). This rate is representative of recent years; the average for the 8-year period 1997-2004 was $2.9 \mathrm{Mgal} / \mathrm{d}$. Injection is a substantial flow of regional magnitude: it is equivalent to 13 percent of regional recharge (table $6 B$ and fig. 19A) or roughly oneeighth the regional discharge along 8.0 miles of coast. The injection plume is 0.93 miles $(1.5 \mathrm{~km})$ wide at the coast, as estimated by numerical modeling (this report). Injected wastewater is assumed to largely displace regional flow over the plume width, although there will be some mixing of effluent and regional freshwater at the lateral margins of the plume. Actual effluent flow rate within the plume will be somewhat greater than the average regional flow rate, and the flow rate of regional freshwater just outside the plume will also be somewhat greater than the average regional rate as a result of the water-table mounding caused by injection and the diversion of regional flow around the plume. However, to describe the situation in the simplest terms, injected wastewater equals about a mile's worth of regional flow, it forms a plume roughly a mile wide along the coast, and it largely displaces regional flow over that mile's width of aquifer.

\section{Nutrient Loads or Fluxes}

Three types of nutrient loads were computed by multiplying sampled nutrient concentrations by applicable groundwater flows containing those concentrations (table $6 C$ ):

1. A background load in regional flow, based on concentrations at the upgradient well;

2. An injected wastewater load, based on concentrations in effluent at the injection source; and

3. An attenuated wastewater load, based on concentrations at the downgradient well and interpreted to reflect dilution and natural attenuation of nutrients in the effluent plume.

The amount of a ground-water-borne nutrient is expressed here as a mass load (mass per unit time) or a mass flux (mass per unit time per unit length of coast).

Ground-water transport of nutrients in the Kihei area can be considered within the following conceptual framework. First, a background nutrient load is envisioned as being carried by regional ground water flowing through the entire study area. This nonpoint-source load is estimated by multiplying the regional volumetric ground-water flow rate (recharge, in this case) by background nutrient concentration at the upgradient well. It is not strictly a "natural" load because it likely includes some amount of nutrients from farms and rural homesteads along the upper road at 3,000 feet elevation. Next, a point-source injected wastewater load is computed by multiplying the volumetric injection rate by nutrient concentration in the treated effluent.

Finally, considering the evidence of nutrient attenuation in the effluent plume (figs. 14, 16), it is worthwhile to make an alternate estimate of wastewater load that may be more realistic than the injected load. This attenuated wastewater load is computed by multiplying injection rate by nutrient concentration at the downgradient well. This assumes that the downgradient well is representative of the effluent plume, perhaps a reasonable assumption in that water from the well appears to be about three-quarters effluent as estimated from oxygen and hydrogen isotopes (fig. 15). The attenuated nutrient load is less than the injected load but still may overestimate nutrient transport to coastal waters if there is further nutrient attenuation between the downgradient well and the shore. Although not computed here, a nonpoint urban load can also be envisioned. Regional ground water-carrying the background nutrient load from the uplands - will flow beneath the urban strip and pick up additional nutrients (an urban surcharge or subsidy) on its way shoreward. Similarly, outside the study area to the north, an agricultural nutrient load (agricultural subsidy) will be added as ground water flows beneath sugarcane fields there.

Following this conceptual framework, background nutrient load for the study area was estimated at $100 \mathrm{~kg} / \mathrm{d}$ nitrogen $(\mathrm{N})$ and $5.7 \mathrm{~kg} / \mathrm{d}$ phosphorus $(\mathrm{P})$ (table $6 C$ and fig. $19 B$ ). Wastewater injection adds $83 \mathrm{~kg} / \mathrm{d}$ nitrogen and $20 \mathrm{~kg} / \mathrm{d}$ phosphorus to the aquifer-nearly as much nitrogen and 3.5 
times as much phosphorus as the background load (note ratios to background load in table $6 C$ ). However, after attenuation, the attenuated wastewater load is only $40 \mathrm{~kg} / \mathrm{d}$ nitrogen and $2.2 \mathrm{~kg} / \mathrm{d} \mathrm{P}$, or 0.40 and 0.39 times the background nitrogen and phosphorus load for the study area.

This comparison of nutrient loads at a regional scale provides a useful context: it shows that injected loads are on par with, or greater than, regional background loads for a study area of sizable extent. However, a more localized comparison also is desirable because wastewater effluent does not discharge along the entire 8-mile coast of the study area but will instead be confined to the width of the effluent plume. To reconcile this perspective, nutrient loads were divided by relevant coastal lengths (13 km for background load, $1.5 \mathrm{~km}$ for wastewater load) to obtain nutrient mass fluxes, which are expressed in units of mass per unit time per unit length of coast (table 6c and fig. 19c). Results are most readily interpretable as ratios to background flux. Injected wastewater flux distributed across the plume width and with no attenuation is 7.1 and 30 times the nitrogen and phosphorus background flux (table 6C and fig. 19C). Attenuation in the aquifer reduces these ratios to 3.5 and 3.4 times background for the attenuated wastewater nitrogen and phosphorus fluxes (table $6 \mathrm{C}$ and fig. 19D). Phosphorus is attenuated much more than nitrogen, proportionally (consistent with fig. 14).

To summarize, nutrient mass flux within the injected effluent plume is roughly $3 \frac{1}{2} 2$ times background for both nitrogen and phosphorus after attenuation to the level observed at the downgradient well. Whether this elevated nutrient flux fosters greater algal growth within the plume than outside to the north and south is a topic to be considered by marine researchers. Further nutrient additions (urban nutrient load) or reductions (attenuation in the aquifer or in marine sediments prior to discharge at the beach or sea bottom) may also merit study, perhaps using existing irrigation wells, targeted monitor wells, and beach or ocean-bottom pore-water sampling with small-diameter probes.

\section{Comparison of Kihei Nutrient Fluxes with Other Areas in Hawaii}

Estimated ground-water nutrient fluxes at Kihei fell mostly within ranges previously estimated on Maui and other islands in Hawaii (table 7). Background nitrogen flux along the Kihei coast is about four times higher than at Lahaina, Maui, but is about two-thirds the Lahaina agricultural flux and one-third to one-half the flux at two resorts with golf courses on Hawaii Island. Injected wastewater nutrient fluxes at Kihei are several times higher than nonpoint fluxes when computed from effluent source concentrations. However, after nutrient attenuation in the injection plume, attenuated wastewater fluxes at Kihei are comparable to nonpoint resort and golf-course fluxes. Injected nutrient flux per length of coast at Kihei (before attenuation) is one-third to one-quarter that at Lahaina for nitrogen and phosphorus, largely because the
Kihei plume is 2.5 times wider; injected nutrient mass is more closely comparable at both locations.

Nutrient fluxes in table $7 A$ are expressed as mass per unit coastline as a means of comparing one area to another, otherwise mass loads could differ simply because of differentsized study areas and coastline lengths. It also is a means of comparing point-source loads to nonpoint loads by choosing coastal lengths applicable to each. Regional nonpoint fluxes (background, natural, agricultural, urban) typically were computed in each study by taking water-budget estimates of ground-water recharge, multiplying by representative nutrient concentrations from sampled wells, and then dividing by the coastline length of the area. Point-source fluxes (injection wells) or small-area fluxes (housing tracts with cesspools) were computed by taking a known or estimated effluent rate, multiplying by nutrient concentrations in the effluent, and then dividing by the length of affected coast (width of injection plume or housing tract). Molar units used in some the cited references have been converted to consistent mass units here. Results can be interpreted as terrestrial ground-water nutrient fluxes - that is, nutrient loads carried by ground water in aquifers on land. These estimates may differ from fluxes actually reaching the sea if nutrients are naturally attenuated in aquifers or coastal sediments prior to ground-water discharge or if there are additional nutrient contributions between sampled wells and shore that have not been included.

A notable first observation from table 7 is that all terrestrial nutrient fluxes, even background fluxes, are several times greater than seawater nutrient fluxes. Therefore, the land is a source of elevated nutrient flux to coastal waters even in the absence of concentrated anthropogenic sources, such as fertilizers and wastewater effluents.

Next, in comparing regional background fluxes, the background nitrogen flux at Kihei $(7.7 \mathrm{~kg} / \mathrm{d}-\mathrm{km})$ is roughly four times the natural nitrogen flux estimated for Lahaina $(1.8 \mathrm{~kg} / \mathrm{d}-\mathrm{km})$. The higher background flux at Kihei is due largely to a higher nitrogen concentration: $1.17 \mathrm{mg} / \mathrm{L}$ TDN and $1.11 \mathrm{mg} / \mathrm{L}$ DIN (table 2), nearly three times the Lahaina natural concentration of $0.3 \mathrm{mg} / \mathrm{L}$ DIN (Dollar and Andrews, 1997). Higher background nitrogen concentrations at Kihei may result from a greater density of nitrogen-fixing trees in the uplands, such as Prosopis pallida (kiawe or mesquite) and Leucaena leucocephala (koa haole or lead tree). Farms and rural homesteads along the upper road at 3,000 feet elevation may also contribute anthropogenic nitrogen, including that from fertilizers. The Kihei background nitrogen flux $(7.7 \mathrm{~kg} / \mathrm{d}$ $\mathrm{km}$ ) is lower than the Lahaina agricultural flux (13 kg/d-km) and the larger of the cesspool fluxes $(9.1 \mathrm{~kg} / \mathrm{d}-\mathrm{km})$ at Lahaina, being 60 percent and 86 percent of those values. Background phosphorus flux at Kihei $(0.44 \mathrm{~kg} / \mathrm{d}-\mathrm{km})$ is 73 percent of the natural flux at Lahaina $(0.6 \mathrm{~kg} / \mathrm{d}-\mathrm{km})$.

Injected wastewater nitrogen flux at Lahaina $(180 \mathrm{~kg} / \mathrm{d}-$ $\mathrm{km}$; Soicher and Peterson, 1996) is more than three times the flux at Kihei $(55 \mathrm{~kg} / \mathrm{d}-\mathrm{km})$, when both are estimated at the injection source (table $7 A$ ). This is due more to a difference in estimated plume width, which is 2.5 times greater at Kihei 
Table 7. Comparison of ground-water nutrient fluxes at Kihei, Maui, and elsewhere in Hawaii.

[Mgal/d-mi, million gallons per day per mile; --, not given; significant figures are mostly consistent with the cited literature sources; original units have been converted to consistent mass and volumetric units for comparison purposes]

\section{A. Nutrient flux in ground water}

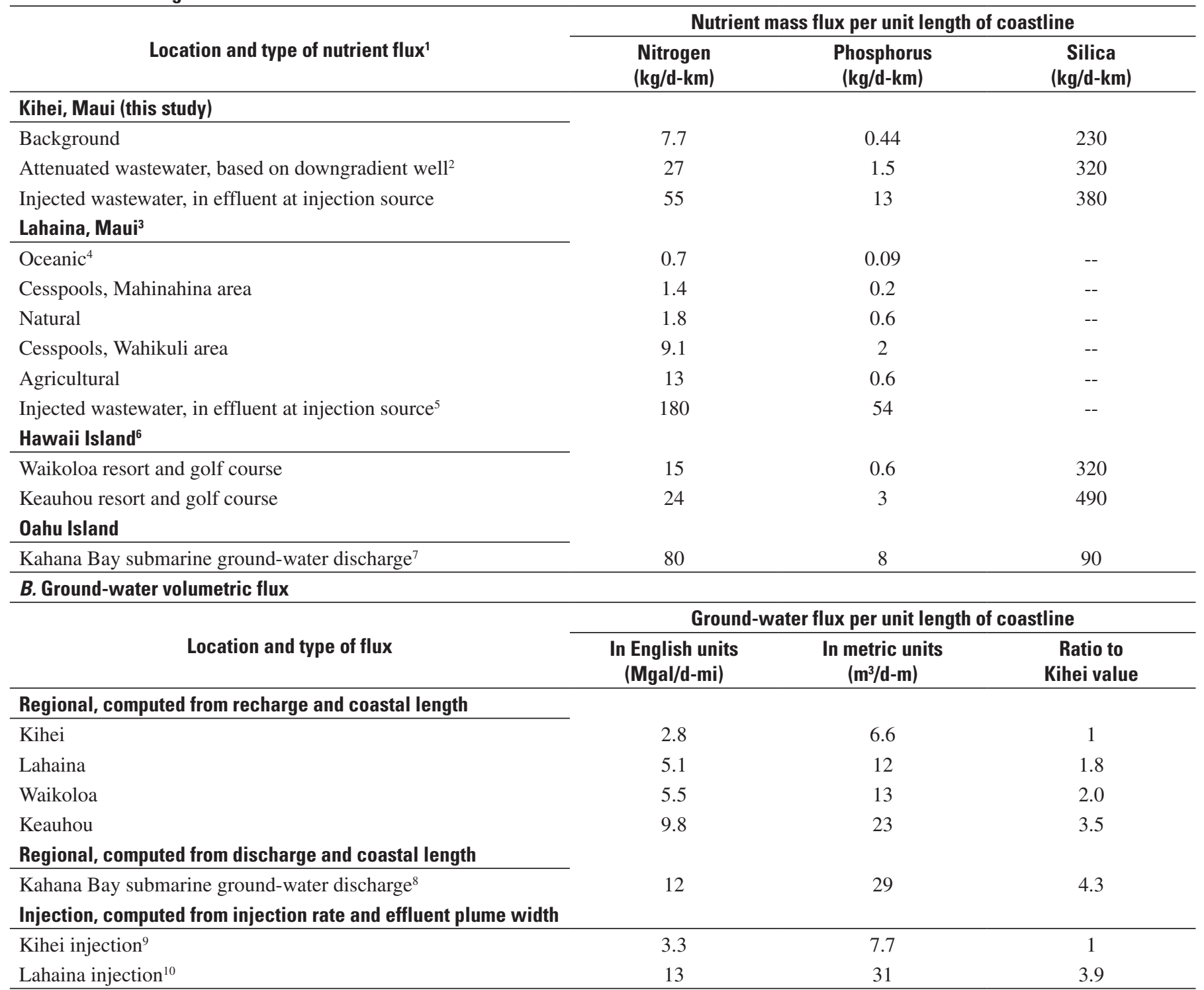

${ }^{1}$ Listed in increasing order of nitrogen load within each area.

${ }^{2}$ Based on concentrations at the downgradient well; presumed to reflect nutrient attenuation in the effluent plume.

${ }^{3}$ From Dollar and Andrews (1997), except injected wastewater.

${ }^{4}$ Nutrient load contributed by oceanic currents; not a ground-water load.

${ }^{5}$ Injected nutrient load from Soicher and Peterson (1997) divided by 0.61-km plume width from Tetra Tech (1994).

${ }^{6}$ From Dollar and Atkinson (1992).

${ }^{7}$ From Garrison and others (2003) using bottom seepage meters; their nutrient load divided by 0.5 -km width of bay (my estimate). Not solely a terrestrial ground-water load, also Includes nutrient contribution from sediment diagenesis.

${ }^{8}$ From Garrison and others (2003); their terrestrial component (16\%) of submarine ground-water discharge measured with bottom-seepage meters, divided by $0.5-\mathrm{km}$ width of bay (my estimate).

${ }^{9}$ Injection rate $3.0 \mathrm{Mgal} / \mathrm{d}$ divided by $1.5-\mathrm{km}$ plume width from model simulation, this study.

${ }^{1}$ OInjection rate $5.0 \mathrm{Mgal} / \mathrm{d}$ (Soicher and Peterson, 1997) divided by 0.61-km plume width (Tetra Tech, 1994). 
than at Lahaina $(1.5 \mathrm{~km}$ versus $0.61 \mathrm{~km})$, than to a difference in injected nitrogen mass, which is greater at Lahaina by a factor of 1.3 (110 kg/d versus $82 \mathrm{~kg} / \mathrm{d}$ at Kihei). Injected phosphorus flux at Lahaina is slightly more than four times that at Kihei (54 kg/d-km versus $13 \mathrm{~kg} / \mathrm{d}-\mathrm{km})$, again due more to the difference in plume width than injected phosphorus mass (33 $\mathrm{kg} / \mathrm{d}$ at Lahaina versus $20 \mathrm{~kg} / \mathrm{d}$ at Kihei).

Attenuated wastewater nutrient flux at Kihei is comparable to resort and golf course fluxes on Hawaii Island (Dollar and Atkinson, 1992). The $27 \mathrm{~kg} / \mathrm{d}-\mathrm{km}$ nitrogen flux at Kihei is 12 percent higher than the larger of the Hawaii estimates (24 $\mathrm{kg} / \mathrm{d}-\mathrm{km}$ at Keauhou) and the $1.5 \mathrm{~kg} / \mathrm{d}-\mathrm{km}$ phosphorus flux at Kihei falls between the Waikoloa and Keauhou estimates (0.6 and $3 \mathrm{~kg} / \mathrm{d}-\mathrm{km})$. On Oahu, nitrogen and phosphorus fluxes in submarine ground-water discharge at Kahana Bay are comparable to injected wastewater fluxes at Kihei and Lahaina and are several times higher than terrestrial nonpoint fluxes. This is because the submarine fluxes at Kahana included additional nutrient contributions from transformation of organic matter within benthic sediments (Garrison and others, 2003) and so are not strictly comparable to on-land estimates of nonpoint fluxes.

The arid climate at Kihei is reflected in a comparison of ground-water fluxes (table $7 B$ ). The Kihei regional groundwater flux of $2.8 \mathrm{Mgal} / \mathrm{d}$-mi is the lowest of all the areas. Regional fluxes at Lahaina and Waikoloa are about twice that at Kihei, and flux at Keauhou is more than three times as great. The largest regional flux is $12 \mathrm{Mgal} / \mathrm{d}-\mathrm{mi}$ at Kahana Bay on Oahu, more than four times the Kihei flux. As for injection fluxes, the volumetric injection flux at Lahaina is 4 times greater than at Kihei, but again this is due largely to the smaller plume width at Lahaina; the actual volumetric injection rate is greater at Lahaina $(5 \mathrm{Mgal} / \mathrm{d}$ versus $3 \mathrm{Mgal} / \mathrm{d}$ at Kihei) but only by a factor of 1.7 .

\section{Limitations of the Flux Estimates}

These computations establish a framework for evaluating and comparing nutrient fluxes within the study area and with other areas. Kihei estimates are poorly constrained by the very few water samples and could be much improved by additional sampling. Furthermore, the few samples are assumed to approximate representative or average concentrations over time. The validity of this assumption is well-founded for the treated effluent (plant records show that nutrient concentrations do not vary much) but is wholly unknown for the wellwater samples, and repeat sampling would be needed to assess variation over time and estimate average concentrations.

Background nutrient load and injected wastewater load at the source are probably the best-constrained estimates at Kihei. Background load is based on the upgradient well, but the cross-gradient well also had similarly low nutrient concentrations and both wells appear to reflect background water quality in the area. The injected wastewater load was estimated straightforwardly at the source.
Estimated with lesser confidence is the attenuated wastewater load, which depends largely on how representative the downgradient well is of the effluent plume in general. Several lines of evidence (nutrients, isotopes, pharmaceuticals) indicate that the downgradient well withdraws modified wastewater, and stable isotopes suggest that it is about 75 percent effluent. However, the attenuated wastewater load is estimated from apparent nutrient attenuation at this single well, and samples from more wells (especially monitor wells specifically sited for such a purpose) would be needed to increase the statistical confidence of the estimate. Because the downgradient well is open to coastal sediments, it is unclear whether the apparent nutrient attenuation is more characteristic of the sediments or the volcanic-rock aquifer between the well and the injection source (again, targeted monitor wells could help answer this question). More sampling is needed to determine whether nutrients are further attenuated between the downgradient well and the shore.

Ground-water flow and discharge were presumed equal to ground-water recharge. Ground-water withdrawals were not subtracted because withdrawals within the study area are small and are used for landscape irrigation, which recycles some of that water back into the ground-water flow system (irrigationreturn recharge). Imported tap water and reclaimed water also are applied for irrigation, again with some return infiltration.

Ratios and percentages comparing injection fluxes to regional fluxes are somewhat subjective because the regional study-area delineation was largely arbitrary. However, the study area does extend several times farther along the coast than the modeled width of the injection plume, which makes for a reasonable study-area extent in lieu of well-defined hydrologic boundaries. The injection-plume width is a reasonable first-order estimate based on a minimally calibrated ground-water model.

\section{Simulation of Regional Ground-Water Flow and Wastewater Injection}

A three-dimensional numerical model was used to simulate regional ground-water flow and wastewater injection at Kihei Wastewater Reclamation Facility. The objectives were to evaluate injection-plume behavior and to make first-order estimates of plume width at the shore. In the model, wastewater effluent having a salinity of 1 percent seawater was injected within a salinity interval of 15-100 percent in the freshwatersaltwater transition zone. Effluent floated to the upper part of the freshwater lens as a buoyant plume and spread out laterally, displacing and mixing with surrounding ground water as it flowed shoreward. The simulated injection plume is 0.93 miles wide $(1.5 \mathrm{~km})$ at the coast, where discharge from the central core of the plume is roughly 60 percent effluent and has an age of less than 5 years since injection. Ambient ground water from upland recharge is about 15-20 years old at the shore, according to the model. 


\section{The Numerical Model}

The numerical modeling code SUTRA was used to construct a three-dimensional ground-water model of the Kihei area. SUTRA is a finite-element code capable of simulating saturated or unsaturated density-dependent ground-water flow with solute or energy transport. Governing equations and computational details can be found in the model documentation (Voss and Provost, 2002). Modeling was accomplished, and results were visualized and interpreted, using several pre- and post-processing software packages grouped under the umbrella of SutraSuite (Provost, 2004). Auxiliary software packages included SutraGUI (Winston and Voss, 2004), Model Viewer (Hsieh and Winston, 2002), and GW_Chart (Winston, 2000). SutraGUI utilizes the Argus Open Numerical Environments (Argus ONE) commercial software as an underlying layer for its mesh-generation and data-assignment capabilities (Argus Interware, Inc., 1997).

For this study, saturated density-dependent flow was simulated with transport of a single, non-reactive solute (in this case, sea salt). This allowed the regional freshwater-saltwater lens to be modeled, properly accounting for mixing of the two end-member fluids and buoyancy resulting from fluiddensity differences. Nutrient transport was not simulated, and modeling results were evaluated mainly in terms of salinity and effluent-tracer concentration. Consistent metric units were used, with conversion to English units where necessary at the interpretation stage. Simulation time steps varied, typically being 2-5 days during most of a simulation and as little as 0.1 day at the start and end of a simulation to maintain minimal numerical error on startup and in final output.

Main simulation objectives were to make first-order estimates of injection-plume size and shape, and to show key aspects of plume behavior under steady-flow conditions. Consistent with these objectives and a lack of data for the area, model calibration is minimal and it is best considered a "reconnaissance-level" model in terms of parameter certainty. On the other hand, the model is spatially detailed, it incorporates necessary processes, such as dispersion and buoyancy, and boundaries and fluid fluxes have been assigned realistically for the most part. Despite its limitations, the model allows reasonable and informative visualizations of the injection plume.

\section{Model Mesh}

A three-dimensional, finite-element mesh was designed to simulate ground-water flow throughout much of the study area (fig. 20). The entire study area was modeled initially, but the mesh extent had to be reduced to achieve practical computation times. Only one injection well was actually modeled because, typically, just one is used at any given time. "Finite elements" of the model are hexahedrals (six-sided blocks) of varying size that adjoin their neighbors along common faces. "Nodes" are points of intersection at the corners of the ele- ments. Fluid pressure and solute concentration are computed at the nodes, whereas elements represent aquifer material within which water flows and is stored. The mesh contains 74,592 elements and 80,256 nodes, with 63 elements in the long dimension (east-west), 32 elements in the transverse dimension (north-south), and 37 vertical elements or layers. The number of nodes in each dimension is one more than the number of elements. Elements are smallest near the shore and injection well, where high fluid velocities and sharp concentration gradients were expected. Minimum areal dimensions of the elements are $10 \mathrm{~m}$ near the shore and $25 \mathrm{~m}$ surrounding the injection well. The largest element at the inland end of the mesh is $300 \mathrm{~m} \mathrm{x} 1,800 \mathrm{~m}$.

Element thicknesses are much smaller than element areal dimensions (fig. 21). Beginning at the top of the mesh, there are 5 elements with $1 \mathrm{~m}$ thickness, then 3 elements $2 \mathrm{~m}$ thick, 18 at $3 \mathrm{~m}$ thickness, 5 at $5 \mathrm{~m}, 3$ at $10 \mathrm{~m}$, and one element each at $20 \mathrm{~m}, 30 \mathrm{~m}$, and $50 \mathrm{~m}$ thicknesses. The mesh extends from sea level to a total depth of $220 \mathrm{~m}$ (722 ft) below sea level, about three times the maximum freshwater thickness simulated. The top of the mesh follows sea-bottom bathymetry offshore (National Geophysical Data Center, 2004). On land, the top of the mesh is at sea level everywhere; pressures approximating water-table height were computed along the top of the mesh, but the water table was not explicitly simulated. This amounts to an error in theoretical freshwater thickness of $1 / 41$ (neglecting vertical gradients), or a maximum of $1.8 \mathrm{~m}$ out of a maximum $74 \mathrm{~m}$ freshwater thickness within the modeled region.

\section{Model Boundary Conditions and Correspondence to Actual Hydrologic Boundaries}

Boundary conditions and fluid sources were assigned to the model and held steady throughout simulations (fig. 22). They were:

- Specified fluid source equal to recharge rate along the top of the model, on land;

- Specified fluid source equal to injection rate along the vertical injection-well interval;

- Specified pressure equal to seawater submergence depth on the sea bottom (top of model, offshore) and along the offshore vertical face of the model;

- No-flow boundaries on the north, south, bottom, and far-inland vertical face of the model.

Boundary conditions were assigned by SutraGUI (Winston and Voss, 2004), which apportions fluid sources among model nodes, pro-rating by the sizes of adjoining elements where appropriate. Recharge was entered by overlaying the map of figure 11 and assigning a salinity of 0.3 percent seawater (the freshest ground-water salinity observed in the area 


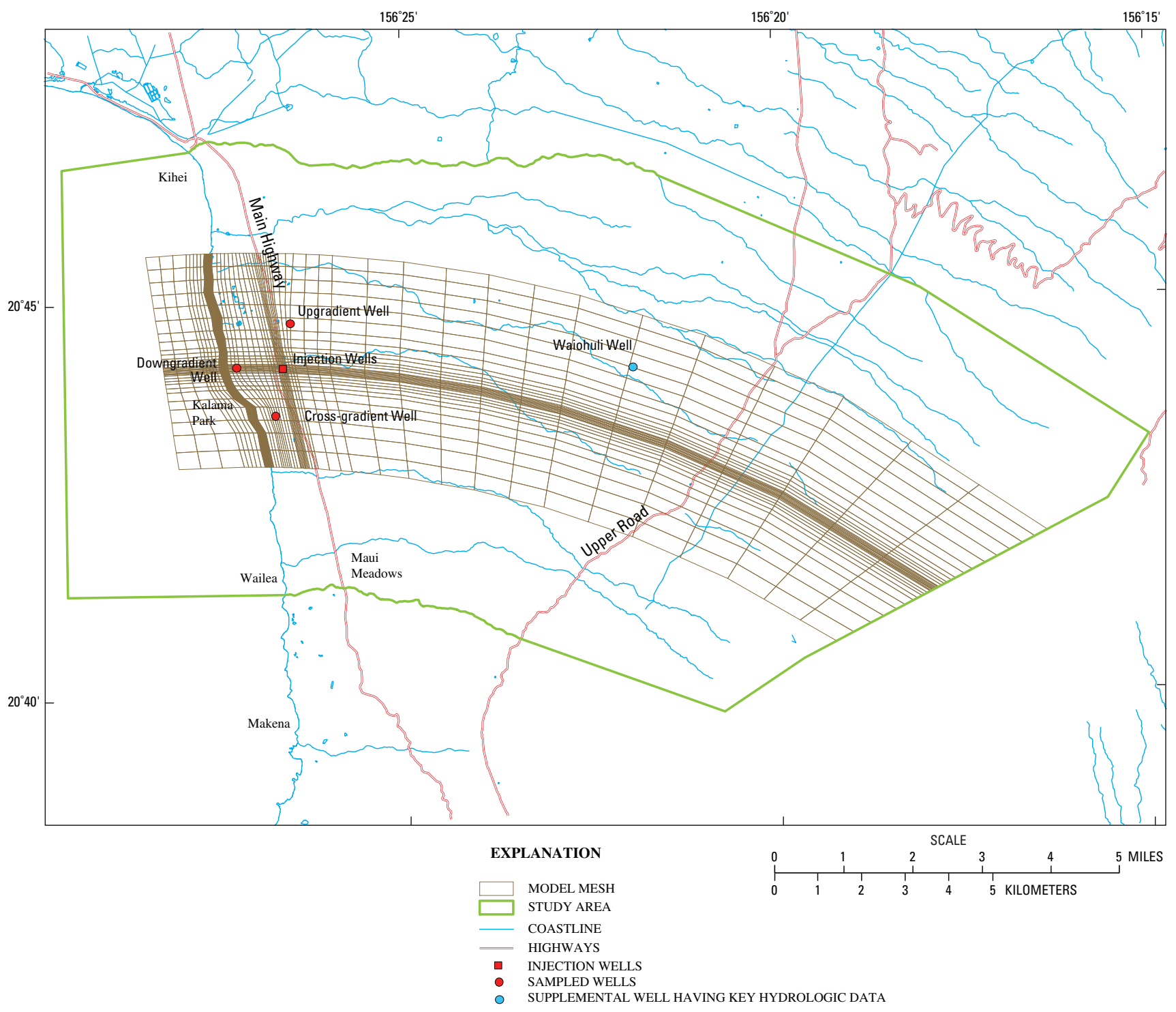

Figure 20. Map showing the finite-element mesh for the three-dimensional ground-water model, Kihei, Hawaii. The mesh is aligned roughly east-west along the presumed direction of regional ground-water flow, and mesh spacing is finest around the injection wells and along the coast. Data from sampled wells and the Waiohuli well were used for model calibration. Vertical details of the mesh are shown in figure 21. 


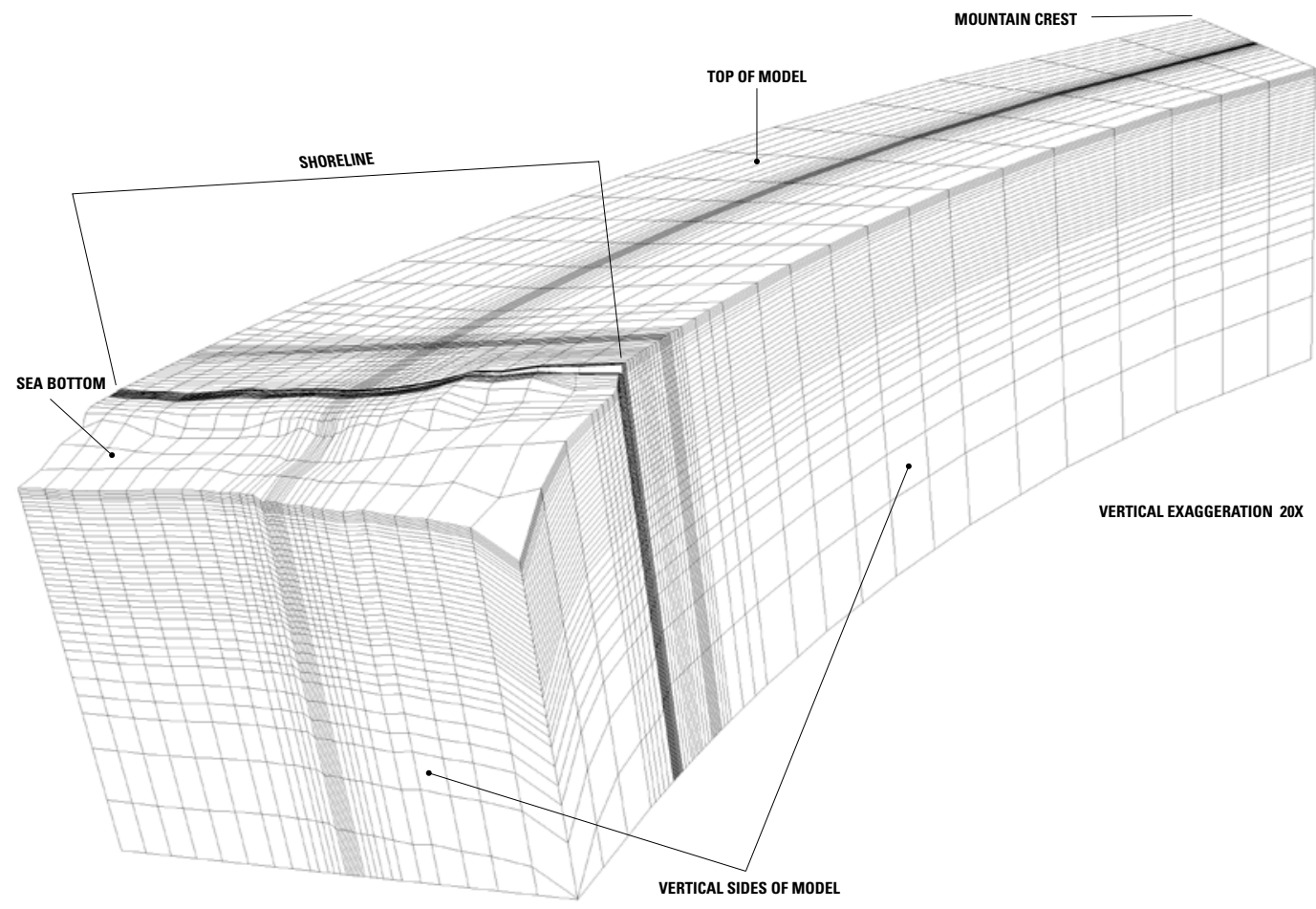

Figure 21. Block diagram showing the model finite-element mesh, Kihei, Hawaii. View is to the northeast. The model has 37 layers of elements, and vertical mesh spacing is finest at the top and progressively coarser with depth.

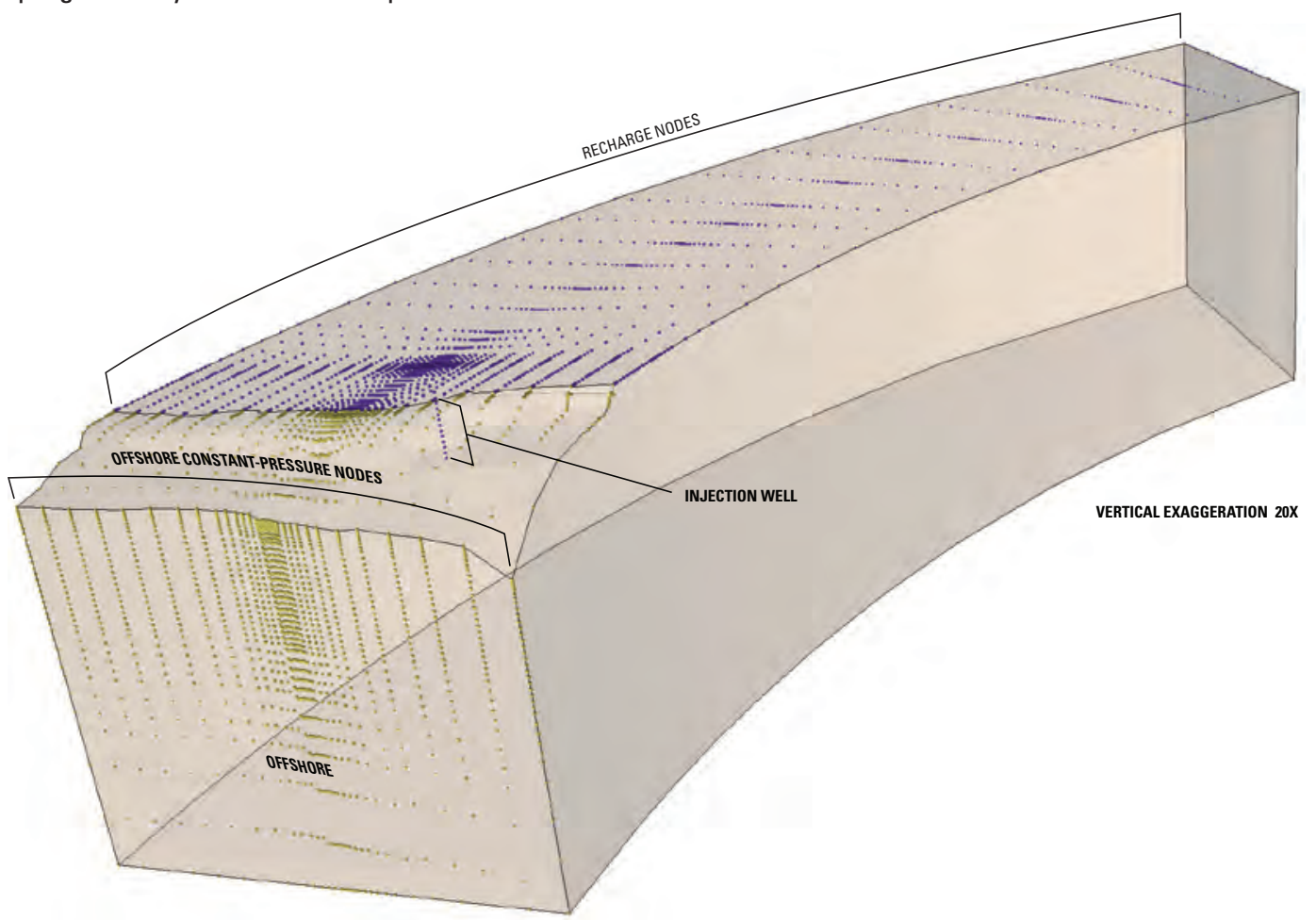

Figure 22. Block diagram showing model boundary conditions, Kihei, Hawaii. View is to the northeast. Recharge and seawater boundary conditions are shown as purple and yellow nodes on the top and offshore face of the model. Purple fluid-source nodes mark the injection interval from $14 \mathrm{~m}$ to $52 \mathrm{~m}$ below sea level. A no-flow boundary condition was applied to the bottom, north, south, and far-inland sides of the model. 
at the far inland Waiohuli well). Injection was apportioned among the 13 injection nodes and assigned the observed effluent salinity of 1 percent. Offshore specified pressures were computed consistent with seawater submergence depth; that is, the depth of each node below sea level times seawater density times gravity. Fluid can flow into or out of the model depending on whether pressures at internal model nodes are less or greater, respectively, than specified pressures at boundary nodes. Inflowing fluid was assigned a seawater concentration and outgoing fluid had the concentration computed inside the model, whatever that happened to be.

Recharge, injection, sea-bottom, and far-inland boundary conditions correspond realistically to hydrologic boundaries in the real world. Recharge is applied across the top of the model as if it were arriving by vertical infiltration to the water table. Sea-bottom pressures were consistent with bathymetry. The far-inland boundary follows the crest of the mountain and presumed central axis of the southwest eruptive rift zone of the volcano, which are surface- and ground-water divides, respectively, and are consistent with a no-flow boundary concept (no flow across the boundary).

Remaining model boundaries are arbitrary and do not correspond to actual hydrologic boundaries; they simply result from excising a modeled region that is computationally tractable and reasonable for the steady-flow simulations of this modeling exercise. The north and south no-flow boundaries are roughly parallel to expected freshwater flow directions (westward, from uplands to shore) and strong flows across them are not expected under steady conditions. The bottom of the model is three times deeper than the thickest freshwater and is parallel to inflowing saltwater in the dispersion-driven circulatory flow field. Placement of this boundary is not likely to have much effect on results of steady simulations, particularly because flow velocities are much slower in the circulatory saltwater flow field than in the freshwater lens. The offshore vertical face was placed arbitrarily, and saltwater inflow through it and the sea bottom are unrestricted, subjected only to the high hydraulic conductivity of the volcanic-rock aquifer (a very "open" sea-boundary condition). Confining sediments at the sea bottom and onshore were not modeled, and the offshore vertical face was not adjusted as a low permeability boundary or leakance parameter as was done in Oahu models (Souza and Voss, 1987; Gingerich and Voss, 2005). Sediments are much thinner at Kihei than on Oahu and the open seaboundary condition is thought to be more realistic in this case. Furthermore, there are no data at Kihei with which to calibrate a confined or leakance boundary.

\section{Fluid and Aquifer Properties Used in the Model}

Fluid and aquifer properties for the model were for the most part assigned rather than estimated by calibration (table 8). The main reason for this is a lack of field data to serve as calibration criteria in the Kihei area. Most properties were assigned values identical to two prior studies on Oahu Island by Souza and Voss (1987) and Gingerich and Voss (2005). The only properties that were calibrated by trial-and-error adjustment of the model were hydraulic conductivity and transverse dispersivity. The horizontal-to-vertical anisotropy ratio in hydraulic conductivity $\left(\mathrm{K}_{\mathrm{h}}\right.$ to $\left.\mathrm{K}_{\mathrm{v}}\right)$ was held to the same 200:1 value as in the Oahu studies. The principal permeability axis of the Kihei model was set to dip 4 degrees westward, consistent with the dip or slant of lava flows near the coast at Kihei (Stearns and Macdonald, 1942). Because of this, $\mathrm{K}_{\mathrm{h}}$ and $\mathrm{K}_{\mathrm{v}}$ are actually aligned parallel and perpendicular to a plane dipping 4 degrees.

Seawater was assigned a solute mass-fraction concentration of $0.0357 \mathrm{~kg}$ salt per $\mathrm{kg}$ seawater, the same value used in Oahu studies. In oceanographic terms, this is equivalent to a salinity of $35.700 \%$ (parts per thousand by weight, or grams per kilogram) and a chlorinity of $19.761 \%$, (Stewart, 2005). The equivalent chloride volumetric concentration is 20,255 $\mathrm{mg} / \mathrm{L}$. This "standard seawater" end member was chosen for simplicity and consistency with prior studies; a more locally correct value for Kihei seawater might be selected from local oceanographic studies but was not for this reconnaissance modeling effort. Modeled concentrations were interpreted in terms of salinity expressed in percent seawater. Recharge and injected effluent were assigned at 0.3 percent and 1 percent salinity, respectively, estimated from 66 and $195 \mathrm{mg} / \mathrm{L}$ chloride concentrations at the Waiohuli well and in the effluent. These salinities did not differ markedly if estimated instead from total dissolved solids or specific conductance.

Fluid fluxes assigned to the model (table $8 B$ ) were recharge $(10.6 \mathrm{Mgal} / \mathrm{d}$, as assigned from the digital recharge map of fig. 11) and the known injection rate of $3.0 \mathrm{Mgal} / \mathrm{d}$. Percentages in table $8 B$ show that reducing the modeled area from the entire study area did not introduce undue bias in recharge. Modeled recharge was nearly the same percentage of study-area recharge as modeled area was a percentage of the study area. That is, recharge was reduced proportionally when excising modeled area from study area without skewing or biasing modeled recharge in any evident way.

\section{Modeled Scenarios}

Two steady-flow scenarios were simulated. In the natural recharge scenario, fresh ground-water flow was driven only by recharge at a constant rate, and the simulation was run until steady pressure and salinity distributions were reached; initial conditions were saltwater everywhere and a hydrostatic saltwater pressure distribution (no flow). In the injection scenario, wastewater injection was added (also at a constant rate) and the model was run for 30 years from the ending conditions of the natural recharge simulation. Pressures and concentrations were essentially stable after the 30-year simulation (injection has been underway at Kihei since 1974, or about 30 years). The simulated injection plume was well established at 3 years elapsed time and changed little for the remainder of the 30year simulation, although the rest of the flow system continued to adjust slightly. 
Table 8. Model parameters and fluid flows for the three-dimensional ground-water model, Kihei, Hawaii.

[Pa, pascals; Mgal/d, million gallons per day; --, dimensionless or not applicable. Seawater salinity as mass fraction (mass of salt per mass of fluid) is equivalent to 35.7 parts per thousand $(\% o$ ). Model parameters were assigned values previously used on Oahu except bold and shaded values, which were adjusted in model calibration]

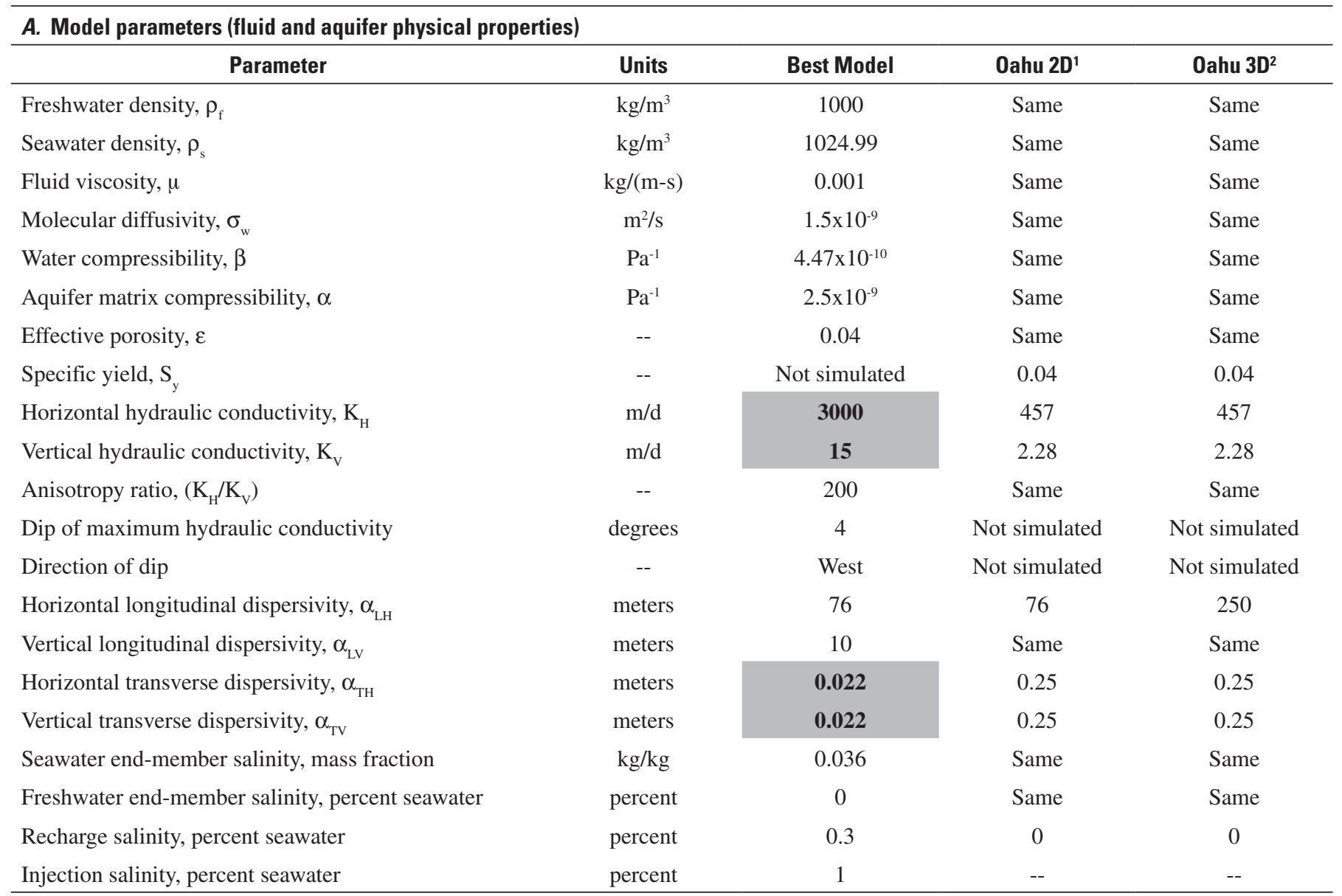

$B$. Modeled fluid flows and comparison with those for the entire study area

\section{Area or volumetric flow rate}

Units
Study area
Modeled area
Modeled area

or recharge as a

percentage of total study area

\begin{tabular}{lcccc}
\hline Area, on land only & $\mathrm{mi}^{2}$ & 73.0 & 33.9 & 46.4 \\
Ground-water recharge rate & & & 10.6 & 46.9 \\
Wastewater injection rate $^{4}$ & $\mathrm{Mgal} / \mathrm{d}$ & 22.6 & 3.00 & -- \\
Injection as percentage of recharge & $\mathrm{Mgal} / \mathrm{d}$ & 3.00 & 28.3 & -- \\
\hline
\end{tabular}

${ }^{1}$ Oahu 2-dimensional model of Souza and Voss (1987).

${ }^{2}$ Oahu 3-dimensional model of Gingerich and Voss (2005).

${ }^{3}$ Recharge was computed by overlaying the GIS (geographic information system) water budget of Shade (1999).

${ }^{4}$ Injection rate is the average for the most recent reporting year September 2003 through August 2004. 


\section{Model Calibration}

The model was calibrated by trial-and-error adjustment of selected parameters. Calibration strategy was to roughly match the height and slope of the water table and the areal salinity distribution at or near the water table, as measured in wells. Table 9 shows calibration targets, simulated values, and fitting errors for two simple datasets: (1) water levels at selected wells and (2) salinities at selected wells computed from sampled chloride concentrations. These few field observations are from this study, from USGS measurements at the Waiohuli well (Gingerich and Sherrod, 2002), and from measurements contained in injection-permit documents (County of Maui, 2004) or State well records (State of Hawaii, 2002). Water levels and chloride concentrations at more wells could have been used (figs. 12 and 13), but large apparent scatter in those data suggests poor intercomparability, possibly due to different measurement dates, inconsistencies in surveyed measuring points, and other factors. Under these circumstances, using more of this data would not necessarily result in a better model.

Calibration was carried out under injection conditions because most field measurements were made during the post1974 period of active wastewater injection. Known groundwater withdrawals of significant size lie south of the modeled area and were not simulated. Target water levels were matched by adjusting horizontal hydraulic conductivity $\left(\mathrm{K}_{\mathrm{h}}\right)$ of the volcanic-rock aquifer, and target salinities were matched by adjusting transverse dispersivity $\left(\alpha_{\mathrm{T}}\right)$; both parameters were assigned universally throughout the entire model domain, they were not varied locally from place to place. Vertical hydraulic conductivity was adjusted in tandem with horizontal conductivity to maintain the anisotropy ratio $\mathrm{K}_{\mathrm{h}}$ to $\mathrm{K}_{\mathrm{v}}$ constant at 200:1 (table 8A). Transverse dispersivity was assigned the identical value in both the horizontal and vertical flow directions.

Fitting errors (table 9) were distributed among the wells to roughly reproduce the general water-table slope and areal salinity distribution, that is, brackish water having several percent salinity about a mile inland and fresher water extending farther inland from there. Simulated values are shown for the shore and far inland boundary, though there are no field measurements at those locations. Root-mean-square (RMS) errors were computed using the most reliable calibration pairs. The downgradient well was excluded from the salinity RMS error, because its large error dominated the resulting value and obscured fitting results at other wells as calibration adjustments were made (effects of including it are shown in table 9 , footnote 4). Observation points in the model were at nodes nearest the wells and in the top layer of the model to simplify pressure conversion to hydraulic head (comparable to watertable height). This introduces a slight error in salinity comparisons between model and wells because midpoints of well open intervals are about $5 \mathrm{~m}$ below sea level and modeled salinity at this depth is slightly greater than at the model top.
Calibration errors (table 9) ranged from -15 percent to +21 percent for water levels and from 0 percent to -15 percent for salinities (excluding the +140 percent error at the downgradient well). Simulated water level at the Waiohuli well could not be pulled any higher without increasing the positive error at the upgradient well, which is closer to the injection area of main interest. Simulated salinity at the downgradient well was 2.4 times too high at 9.2 percent salinity versus target 3.9 percent (table $9 B$ ). A better fit was not attempted for the downgradient well because it lies in an area of steep salinity gradients where small positional shifts in the nearshore mixing zone can have large effects on simulated salinity. Therefore, fit at the downgradient well was intentionally given less priority than at inland wells. Lowering the salinity error at the downgradient well would have required further reduction in transverse dispersivity, which already was set more than an order of magnitude lower than for Oahu (table 8), and at a value that was beginning to affect computational stability in the model.

The calibrated horizontal hydraulic conductivity of 3,000 $\mathrm{m} / \mathrm{d}(9,800 \mathrm{ft} / \mathrm{d})$ is six times greater than the value of 457 $\mathrm{m} / \mathrm{d}$ used on Oahu (table 8) but it does fall within the range of aquifer-test results from pumping tests in the Kihei area (Kolja Rotzoll, University of Hawaii, written commun., 2005). Further refinement of this parameter by fitting would require greater confidence in field water-level measurements, which in turn would require a new round of synoptic measurements and resurveying of measuring-point altitudes. The calibrated transverse dispersivity of $0.022 \mathrm{~m}$ is more than an order of magnitude lower than the $0.25 \mathrm{~m}$ value used on Oahu (table 8). This low value was necessary to reproduce the areal salinity distribution at Kihei; higher values resulted in brackish water extending too far inland. Transverse dispersivity appeared to be the most appropriate and sensitive parameter for matching the areal salinity distribution; adjusting longitudinal dispersivities did not improve fit.

The calibration obtained here can be considered a minimal, first-order calibration with many model parameters assigned rather than calibrated by fitting. Calibration methods used in many modeling studies-such as history-matching to long water-level records - are not possible at Kihei owing to a lack available field data. An exhaustive model-sensitivity analysis to various parameters was not done because modeling objectives (roughly estimating plume geometry and behavior) and calibration were at a reconnaissance level. Effort was instead devoted to visualizing the injection plume to understand how it modifies and interacts with the natural flow system.

\section{Simulation Results}

Salient results of simulation are presented below in a series of comparative maps, cross sections, and block diagrams generated by the Model Viewer post-processing package (Hsieh and Winston, 2002). Results are displayed as salinity (percent seawater) or effluent-tracer concentration (percent 
Table 9. Model calibration targets and fitting errors for the three-dimensional ground-water model with injection, Kihei, Hawaii.

[Water levels in feet above mean sea level; mg/L, milligrams per liter; --, not available; simulation errors and percent error are in bold; black denotes positive error (simulated value greater than target), red denotes negative error (simulated value less than target); RMS, root-mean-square error (red indicates sum of squared errors is negative when signs are retained; values included in the RMS computation are shaded); salinity as percent seawater was computed using a mass-fraction concentration (mass of salt per mass of fluid) of $0.0357 \mathrm{~kg} / \mathrm{kg}$, equivalent to $35.7 \%$ (parts per thousand) and a seawater chloride concentration of $20,255 \mathrm{mg} / \mathrm{L}$; all simulated values are from the top layer of nodes in the model]

\begin{tabular}{|c|c|c|c|c|c|c|c|c|c|}
\hline \multirow{2}{*}{$\begin{array}{l}\text { Field observation, calibration target, or } \\
\text { simulation result }\end{array}$} & \multirow[b]{2}{*}{ Units } & \multicolumn{8}{|c|}{ Water level or salinity } \\
\hline & & $\begin{array}{l}\text { At shore- } \\
\text { line }\end{array}$ & $\begin{array}{c}\text { Downgradient } \\
\text { well }\end{array}$ & $\begin{array}{c}\text { Cross-gradient } \\
\text { well }\end{array}$ & Injection wells & Upgradient well & Waiohuli well & $\begin{array}{l}\text { At } \\
\text { inland } \\
\text { margin }\end{array}$ & $\begin{array}{l}\text { RMS } \\
\text { error }\end{array}$ \\
\hline \multicolumn{2}{|c|}{ State well number: } & -- & $6-4427-04$ & $6-4326-09$ & $6-4426.01$ & $6-4426-03$ & $6-4421-01$ & -- & -- \\
\hline \multicolumn{2}{|c|}{ USGS site identification number: } & -- & 204423156272501 & 204334156264301 & 204411156263800 & 204456156264101 & 204407156215501 & -- & -- \\
\hline \multicolumn{10}{|c|}{ A. Calibration to reported field water-level measurements } \\
\hline Reported water level & feet & -- & -- & 1.58 & 1.4 to $3.6^{1}$ & 1.87 & 5.58 to $6.11^{2}$ & -- & -- \\
\hline Target water level & feet & -- & -- & 1.6 & 2.4 & 1.9 & 5.9 & -- & -- \\
\hline Simulated water level & feet & 0.12 & 0.74 & 1.5 & 2.2 & 2.3 & 5.0 & $6.0^{3}$ & -- \\
\hline Error (simulated minus target) & feet & -- & -- & -0.1 & -0.2 & 0.4 & -0.9 & -- & 0.5 \\
\hline Percent error & percent & -- & -- & $-6 \%$ & $-8 \%$ & $21 \%$ & $-15 \%$ & -- & $14 \%$ \\
\hline \multicolumn{10}{|c|}{ B. Calibration to reported field salinity measurements } \\
\hline Reported chloride concentration & $\mathrm{mg} / \mathrm{L}$ & -- & 788 & 612 & -- & 412 & 66 & -- & -- \\
\hline Target salinity, percent seawater & percent & -- & 3.9 & 3.0 & -- & 2.0 & 0.33 & -- & -- \\
\hline Simulated salinity, percent seawater & percent & 41 & 9.2 & 2.6 & 1.7 & 1.7 & 0.33 & 0.34 & -- \\
\hline Error (simulated minus target) & percent & -- & $5.3^{4}$ & -0.4 & -- & -0.3 & 0.00 & -- & 0.3 \\
\hline Percent error & percent & -- & $140 \%$ & $-13 \%$ & -- & $-15 \%$ & $0.0 \%$ & -- & $12 \%$ \\
\hline
\end{tabular}

${ }^{1}$ Target selected as average of five values $(1.4,1.5,2.75,2.85,3.6)$ from injection permit and renewal applications.

${ }^{2}$ Target selected as average of six values $(5.58,6.11,6.05,5.91,5.71,5.73)$ reported by Gingerich and Sherrod (2002).

${ }^{3}$ Shown in red because target water level at the inland margin of the study area is unknown but probably greater than simulated, judging from fit at Waiohuli well.

${ }^{4}$ Downgradient well excluded from RMS error because it dominates results (small positional shifts in the freshwater-saltwater mixing zone at this site will cause large error); if included, RMS errors are 2.7 percent seawater and 70 percent error and would be in black (positive) instead of red. 
effluent) and are shown as discrete color bands, although actual values are smoothly gradational. Velocity vectors are shown in some figures, but fluid pressures are not displayed because they are difficult to visualize in a useful way and cannot readily be converted to hydraulic head or fluid potential over the range in fluid density in the model. However, pressures at selected observation nodes were converted to equivalent freshwater heads to compare with well-water levels during calibration, and errors associated with this conversion are small because fluid at those nodes was fresh or nearly fresh. In block diagrams and cross sections, the vertical dimension is highly expanded at 20:1 vertical exaggeration.

\section{Salinity Structure of the Freshwater-Saltwater Flow System}

The regional structure of the freshwater-saltwater flow system is shown in figure 23 for natural recharge conditions. The side of the diagram facing the viewer is the south side of the model, and freshwater flows from right to left. Salinity is expressed as percent seawater and is divided at 20 percent intervals into five colored bands. Water fresher than 3 percent is not shown, leaving clear space in the diagram (for reference, freshwater recharge is 0.3 percent). This helps delineate a "fresh core" of the freshwater lens from the underlying mixing zone and creates a shadowed "ledge" that drops off in the inland direction. The 3 percent value was chosen arbitrarily because it made for best delineation of the simulated injection plume - probably because ambient water-table salinity is about 3 percent in the vicinity of the injection wells. For reference, the upper salinity limit for drinking water is about 1.3 percent, but this limit holds little relevance at Kihei because no drinking water is developed there.

At the far inland boundary, the upper third of the model's depth is occupied by fresh and mixed water down to a salinity of 80 percent (bottom of the yellow band). Freshwater thins gradually shoreward and ends at the " 3 percent ledge" before reaching the shore. Salinity bands are laterally continuous and rise at the shore where ground water discharges. Offshore bathymetry is distinguishable as shading, and a steeper dropoff of the sea bottom is apparent in the southern part of the model compared to the sea bottom farther north. Also, the 3 percent ledge lies closer to shore in the south and farther inland in the north.

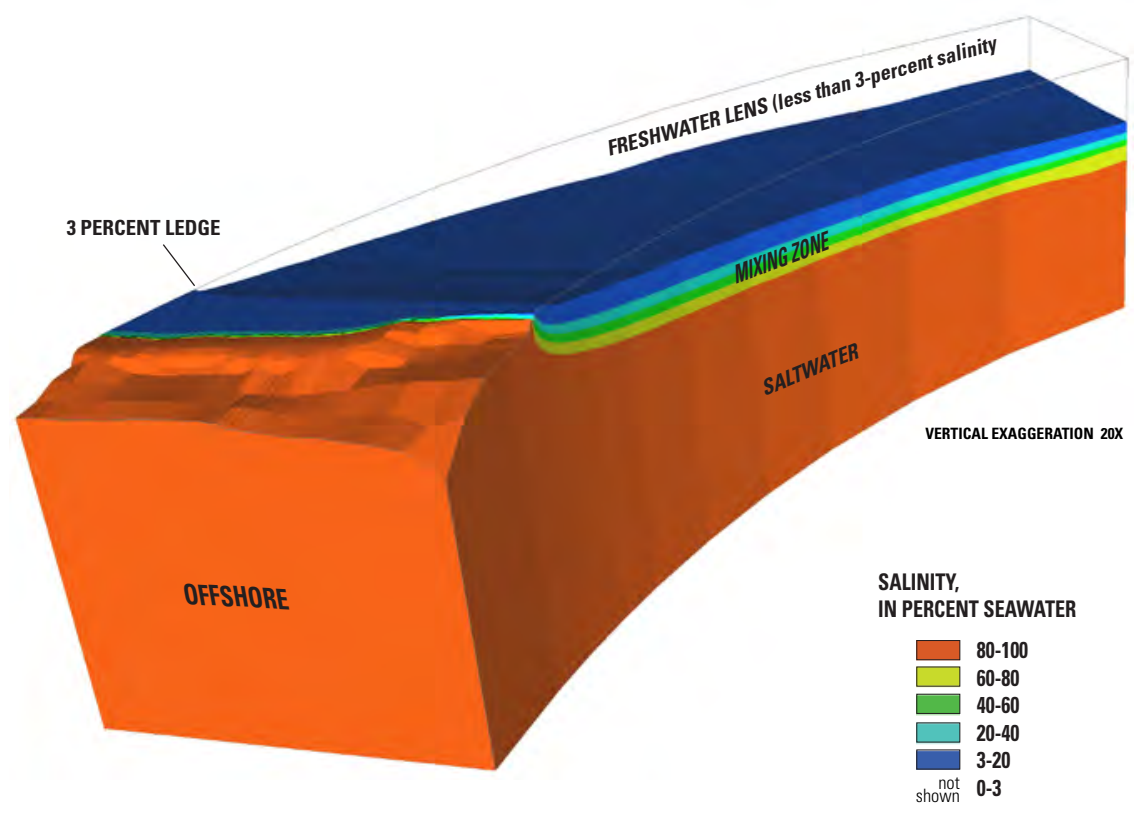

Figure 23. Block diagram showing modeled salinity for the natural recharge scenario, Kihei, Hawaii. View is to the northeast. Water fresher than 3 percent seawater has been omitted from the diagram to delineate the freshwater lens as clear space; ground water shoreward of the " 3 percent ledge" is brackish. Recharge drives ground-water flow from mountain to shore within the freshwater lens, entraining underlying saltwater in the mixing zone. Mixed water discharges at the coast, drawing saltwater into the aquifer from offshore to replace it and driving circulatory saltwater flow at depth. 


\section{Areal Patterns of Flow and Salinity Near the Shore}

Flow and salinity patterns in the nearshore part of the model were somewhat unexpected, even in the natural recharge scenario (fig. 24). Porewater velocity vectors swing southwestward instead of directly west as was presumed during mesh design (fig. 20). Although confining sediments beneath the northern coastal bench can be expected to divert flow southwest, these sediments were not simulated. The most plausible explanation is lesser impedance to ground-water flow and discharge in the south part of the model, where the shoreline curves inland and sea-bottom bathymetry drops off steeply.

Brackish water extends farther inland at the northern end of the model than at the southern end, as seen by the wider aqua salinity band and greater inland displacement of the shadowed 3 percent ledge in the north (fig. 24). This pattern differs slightly from well data (fig. 13) that indicate about 2 percent salinity (roughly $400 \mathrm{mg} / \mathrm{L}$ chloride concentration) in that northern area and comparable salinity in both north and south at similar distances from shore. Modeled salinity at the shore varies along the coast. To the south, where the sea bottom drops off steeply, modeled salinity is less than 20 percent at the shore. Midway up the coast where the sea bottom is shallow, modeled salinity varies between 40 and 60 percent at the shore, which is higher than beach-face water samples that range from 0.28 to 28 percent salinity in this area (Jennifer Smith, University of Hawaii, written commun., 2005). This mismatch between model and reality may reflect misassignment of model parameters (such as dispersivity), features or processes not represented in the model (such as coastal sediments and tides), or a fundamental inability of the regionalscale mesh to adequately reproduce detailed field observations at the shore.

In the injection scenario (fig. 25) the effluent plume takes on the same southwest orientation of the natural flow pattern (fig. 24). The internal core of the plume is revealed by stripping off water fresher than 3 percent salinity (recall that effluent salinity is 1 percent). Regional ground-water flow is diverted around the plume to the north and south, and the plume has an "upstream shoulder" that displaces the 3 percent ledge inland. Buoyant entrainment of underlying brackish water appears to be the main cause of the upstream shoulder, as shown in subsequent diagrams. The plume core does not extend all the way to the coast when outlined at 3 percent salinity, because effluent mixes with surrounding and underlying brackish water. Plume definition-strictly in terms of salinity-is lost within a short distance, and lines of equal salinity simply run parallel to the coast. This is apparent in figure 25 at 20 percent salinity (division between blue and aqua) but can also be seen as low as 7 or 8 percent salinity when results are mapped in finer detail (not shown).

An alternate visualization (fig. 26) —using a conservative effluent tracer rather than salinity-better delineates the injection plume and shows its full extent all the way to the shore where it discharges. [A "conservative" tracer is subject only to dilution; its concentration does not change as a result of decay, degradation, or sorption]. In this visualization, color bands correspond to effluent concentration, with 100 percent effluent at the injection source. The internal core of the plume is revealed by stripping off fluid that is more than 90 percent effluent. The apparent outer limit of the plume (aqua) is at 20 percent effluent as a result of maintaining simple color bands. However, a later diagram delineates the plume out to a limit of 5 percent effluent, which was chosen as an arbitrary convention to define plume width. The blue band here comprises all water less than 20 percent effluent, including saltwater and freshwater end members, which both lie within the lowermost 1 percent concentration in this tracer scheme.

The effluent tracer visualization of figure 26 was created in a post-processing step that takes advantage of the computational sequence in the SUTRA model code (Alden Provost and Clifford Voss, U.S. Geological Survey, written commun., 2005). Following the main injection simulation, final results were used as initial conditions for a single, 30-year long computational time step during which the flow field (velocity field) was held constant and only the concentration field was recomputed. Initial concentrations ranged from freshwater to saltwater as before, but injected fluid was assigned a concentration 100 times that of seawater, which enabled effluent to stand out as a highly concentrated tracer. Effluent still mixed with surrounding water, as governed by fluid velocity and aquifer dispersivities, but no additional buoyancy effects were induced by the concentrated tracer because the velocity field (which includes buoyancy) was not recomputed.

\section{Vertical Structure and Flow Dynamics of the Injection Plume}

The three-dimensional structure of the injection plume can be examined in block diagrams and cross sections. The fresh core of the effluent plume and its relation to the regional freshwater-saltwater mixing zone are visible in figure 27 , which is a salinity visualization with color bands at 20 percent intervals and with water fresher than 3 percent stripped off as in figure 25. Despite an injection interval that extends through the mixing zone into underlying saltwater, injected effluent nevertheless rises buoyantly and spreads out at the top of the flow system as a consequence of its low salinity (1 percent) and correspondingly low fluid density. The upstream shoulder of the plume is apparent, and the upward bulge in the aqua color band suggests possible upward diversion of water attempting to flow around the plume. Note again that the plume core delineated at 3 percent salinity does not extend to the shore.

A different impression of plume structure is gained from the effluent tracer visualization of figure 28 (color bands are defined at 20 percent intervals of effluent concentration, and water greater than 90 percent effluent has been stripped off as in figure 26). Here, the effluent plume clearly extends to 

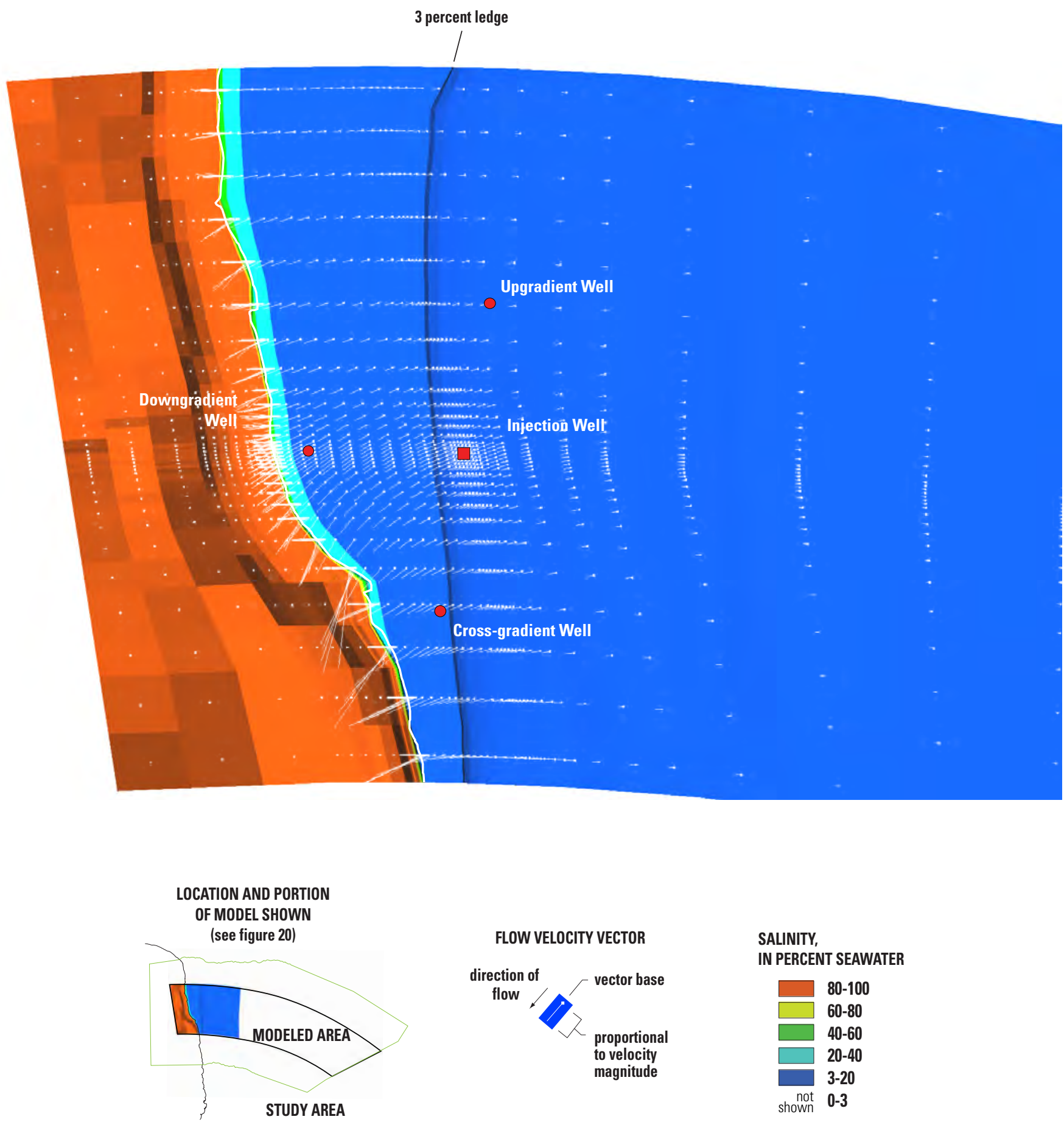

\section{SALINITY, \\ IN PERCENT SEAWATER}

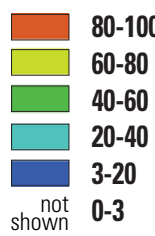

Figure 24. Map showing modeled salinity for the natural recharge scenario, Kihei, Hawaii. Water fresher than 3 percent seawater has been omitted from the map, creating a shadowed line running north-south near the injection wells (" 3 percent ledge" in the blue field). A freshwater lens extends inland from this ledge, but ground water shoreward of the ledge is brackish. Velocity vectors have a southwesterly orientation near the coast, suggesting easier ground-water discharge in the south part of the model, where the coast curves inland and the sea bottom drops off more steeply than it does farther north. 

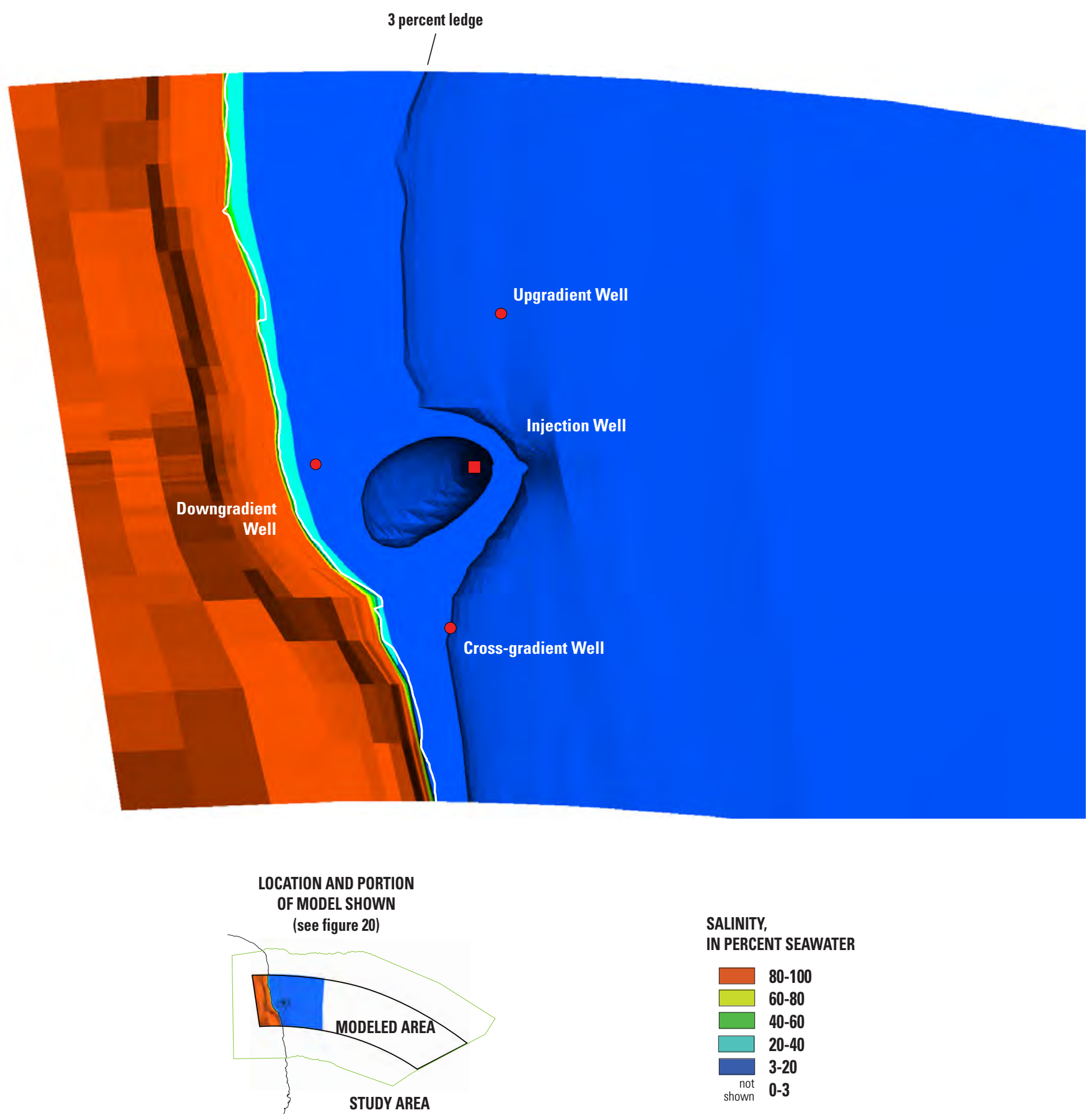

SALINITY,

IN PERCENT SEAWATER

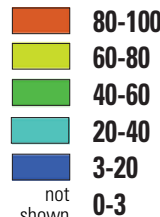

Figure 25. Map showing modeled salinity for the injection scenario, Kihei, Hawaii. Water fresher than 3 percent seawater has been omitted from the map, delineating the fresh core of the injection plume (injected effluent is only 1 percent seawater) and the freshwater lens inland of the " 3 percent ledge." The plume does not appear to extend to the shore in this salinity visualization because mixing of effluent with surrounding brackish water causes loss of plume definition as effluent flows shoreward. Figure 27 shows a corresponding three-dimensional view. 

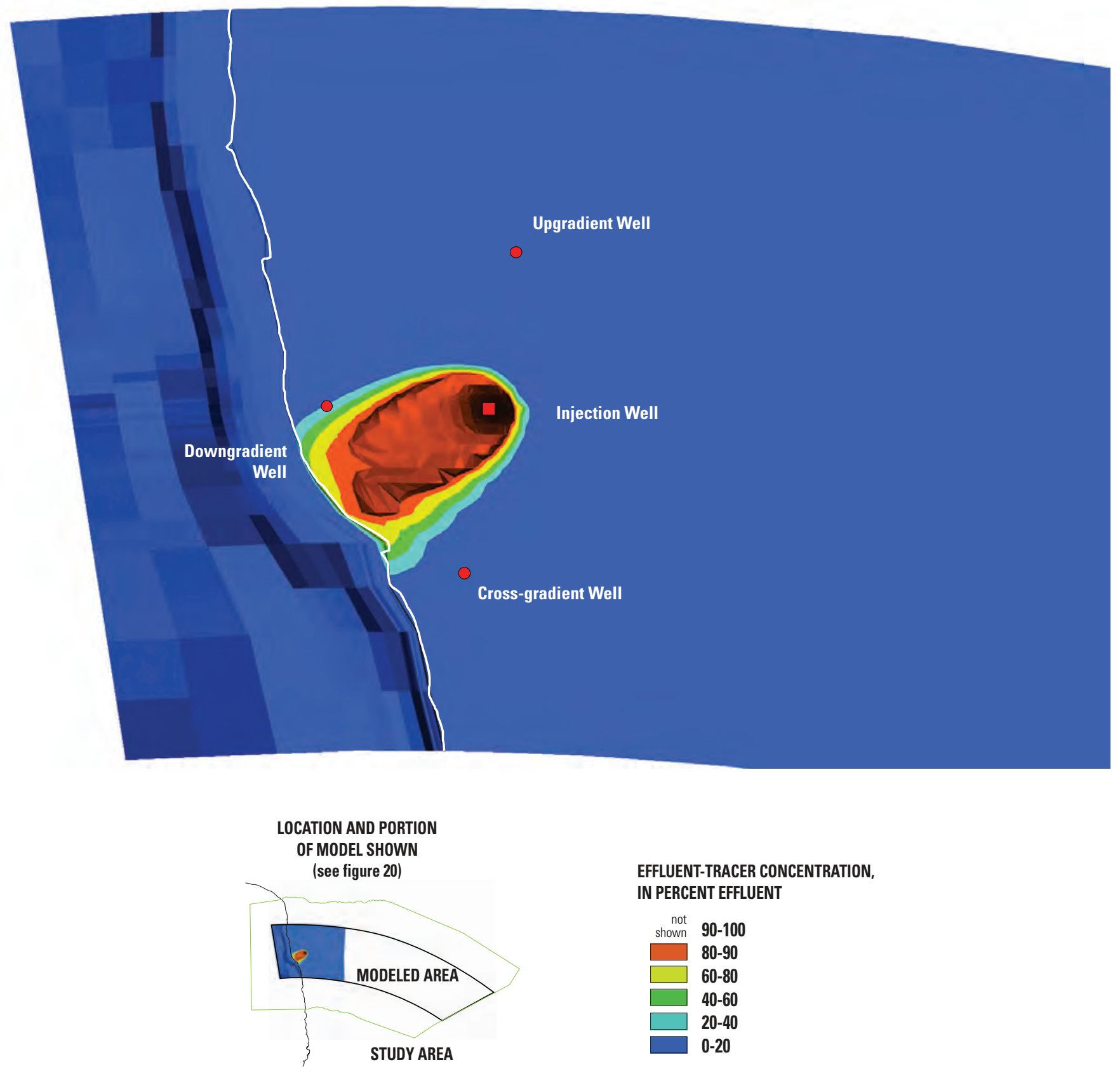

Figure 26. Map showing modeled conservative effluent-tracer concentration for the injection scenario, Kihei, Hawaii. Introducing an effluent tracer in the model demonstrates that the injection plume extends all the way to the shore, where it discharges. Fluid that contains more than 90 percent effluent has been omitted from the map, revealing the plume core. The aqua color band (2040 percent) defines plume extent to an outer limit of 20 percent effluent; the plume extends slightly farther out at lower effluent concentrations, such as 5 percent or 1 percent. Figure 28 shows a corresponding three-dimensional view. 


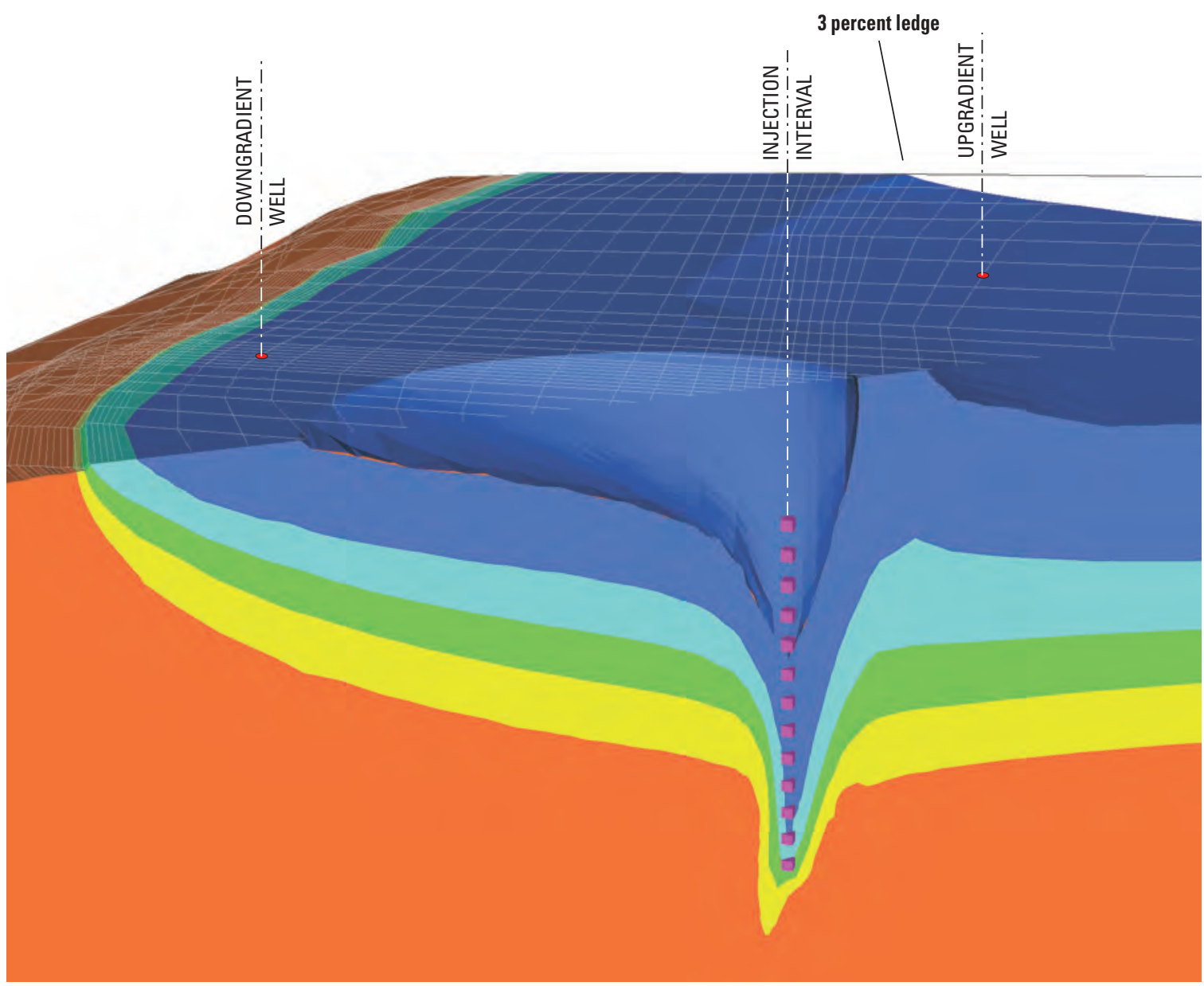

VERTICAL EXAGGERATION 20X

LOCATION AND PORTION

OF MODEL SHOWN

(see figure 20)

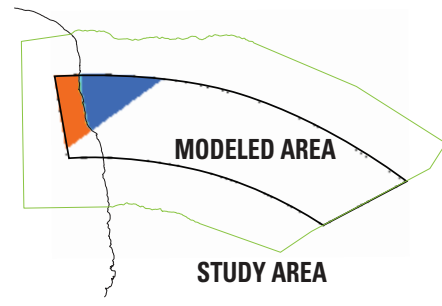

\section{SALINITY, IN PERCENT SEAWATER}

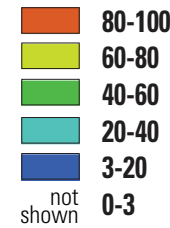

Figure 27. Cutaway block diagram showing modeled salinity for the injection scenario, Kihei, Hawaii. View is to the northwest; line of section is oriented southwest along the plume axis. Water fresher than 3 percent seawater has been omitted from the diagram, delineating the fresh core of the injection plume and the freshwater lens inland of the " 3 percent ledge." The small cubes are fluid-source nodes in the model that correspond to the open interval of the injection well. Low-salinity effluent is injected into the mixing zone and underlying saltwater; it rises buoyantly, spreads out near the top of the aquifer, and flows to the coast. Because effluent mixes with surrounding ground water, plume definition (strictly in salinity terms) is lost before the coast is reached. Figure 25 shows a corresponding map view. 
the shore, where discharge from the plume core is about 60 percent effluent (division between green and yellow) according to the model. The same buoyant rise and shallow spread of effluent noted in the previous diagram is apparent here. In the shoreward direction, effluent grades into underlying water over a substantial depth. In the inland direction, it is apparent that the upstream shoulder encompasses a mixing zone from effluent out to surrounding water along a near-vertical upstream face that parallels the buoyantly ascending effluent.

Velocity vectors illustrate the strong buoyant rise of the low-salinity effluent (fig. 29). This salinity cross section shows water flowing laterally shoreward in the freshwater lens and transition zone, with moderate velocity magnitudes that become larger near the coast, where flow converges and discharges. Mixing pulls a slight saltwater flow in from offshore and upward to participate in the shoreward flow. Largest velocities surrounding the injection interval reflect the high volumetric rate of injection. The upward orientation of most of these vectors is the result of effluent buoyancy; without buoyancy, vectors would emanate roughly horizontally from the well. Mixing and entrainment of brackish and saline water in the rising effluent causes mixed water to also rise buoyantly in the plume. This drives a strong flow of underlying saltwater to resupply that process, as shown by large vectors with vertical components beneath the injection interval. The upstream shoulder of the plume is seen in this figure and corresponds with upward and slightly upgradient flow of injected effluent, as shown by vectors having a lateral component in the inland direction.

A few qualifications are required for proper understanding of figure 29. The large vertical exaggeration (20 times) imparts greater apparent vertical components in vector orientation than actually exist in the field. Flow within the plume has an upward component, but not so steeply upward as is conveyed by vector orientations in the diagram. The downward orientation of a few vectors may result from cross-section alignment along the model centerline rather than along the plume axis - this was necessary in order to display vectors-and components of flow that are not strictly aligned with the line of section. Although the cross section shows lateral components of flow to the left and right, the cross section is just one slice of a three-dimensional flow field (fig. 27). In plan view, effluent will emanate radially from the injection well in all directions. Velocity magnitudes are not quantified in the diagram, but vector lengths are scaled proportionally for correct relative comparison from vector to vector.

\section{Injection Plume Width and Dependence on Model Parameters}

A principal objective of the modeling effort was to estimate the width of the wastewater injection plume where it discharges at the coast. Plume width encompasses 0.93 miles or $1.5 \mathrm{~km}$ of shoreline length as modeled under the calibrated parameter set (table 8). In figure 30, the plume is displayed in terms of conservative effluent-tracer concentration and is mapped to an outer limit of 5 percent effluent and, as before, fluid containing more than $90 \%$ effluent has been omitted. Although 5 percent was chosen as an arbitrary convention for defining plume size, it is estimated to include more than 99 percent of all injected effluent mass. The plume is centered on Kalama Park, and those familiar with the area can select additional orientation landmarks from among the streets and lots outlined by tax-map parcels. Shoreline concentrations in the central part of the plume are as great as 60 percent effluent (division between dark green and light green bands). The downgradient well lies at about 45 percent effluent concentration, whereas water sampled from that well was estimated to contain roughly 75 percent effluent on the basis of stable isotopes (fig. 15). The outer sides of the plume are visible because the plume is wider at middle depths than at the top surface; this allows the plume sides to be seen when viewed from above (map view).

As one measure of parameter sensitivity, the anisotropy ratio of horizontal to vertical hydraulic conductivity $\left(\mathrm{K}_{\mathrm{h}}\right.$ to $\left.\mathrm{K}_{\mathrm{v}}\right)$ was reduced by an order of magnitude, from 200:1 to 20:1. This parameter was chosen because it is one of the less wellknown aquifer properties in Hawaii. Horizontal conductivity was held the same as before at 3,000 m/d but vertical conductivity was increased from 15 to $150 \mathrm{~m} / \mathrm{d}$. The resulting plume (fig. 31) has a more westerly orientation than the prior plume and is broader overall. It extends farther north and not quite as far south and encompasses a longer stretch of shoreline (1.1 miles or $1.8 \mathrm{~km}$ ) than the prior plume. Concentrations at the shore are only about 40 percent effluent in this case (division between aqua and dark green), and the downgradient well lies at a concentration of 75 percent effluent, which agrees with the sampled composition as estimated from stable isotopes (fig. 15).

Viewed in three-dimensional cutaway, the plume is vertically thicker at 200:1 anisotropy (fig. 32) and is thinner and flatter at 20:1 anisotropy (fig. 33). A conjecture is that the lower vertical hydraulic conductivity at 200:1 anisotropy inhibits buoyant rise of the effluent and causes it to spread out laterally at depth in the injection interval. Conversely, the higher vertical hydraulic conductivity at 20:1 anisotropy allows a more direct buoyant ascent of effluent to the surface, where it spreads out more at shallower depths. This is consistent with figure 30, where the sides of the plume at 200:1 anisotropy are visible from above because it bulges out and is widest at intermediate depth. At 20:1 anisotropy (fig. 31) the sides of the plume are not as visible from above because it is widest near the top (at shallow depth).

Similar presentations could be prepared to show effects of other model parameters on the modeled size, shape, and orientation of the injection plume. However, given the minimal level of model calibration and the lack of constraining field data, this would have more theoretical than practical value. These model results are intended as a general guide, and remaining questions about the plume might be better answered by field investigations rather than by modeling. Such investi- 


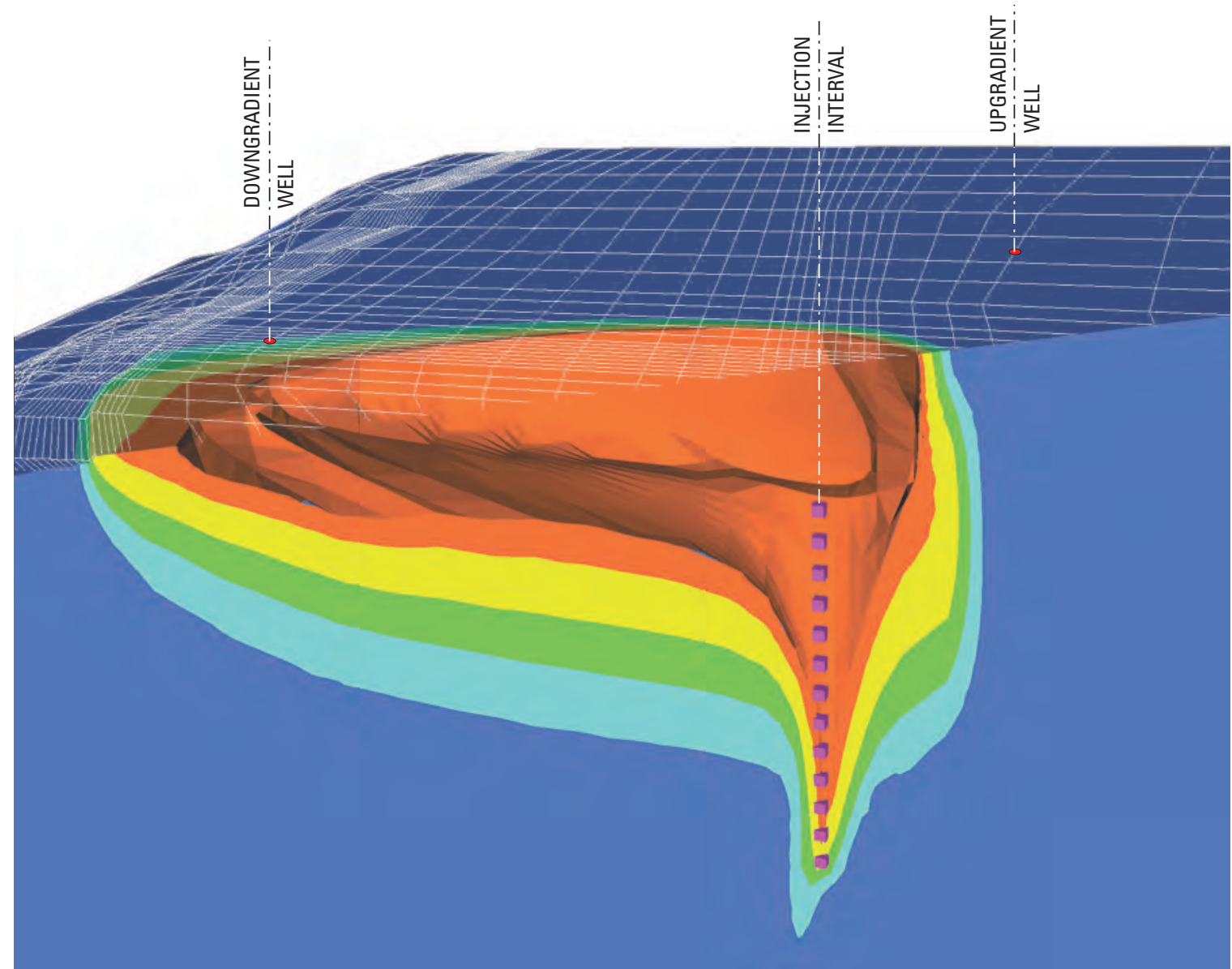

VERTICAL EXAGGERATION 20X

\section{LOCATION AND PORTION OF MODEL SHOWN (see figure 20)}

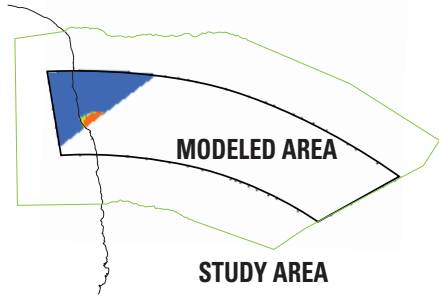

\section{EFFLUENT-TRACER CONCENTRATION, IN PERCENT EFFLUENT}

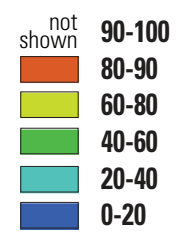

Figure 28. Cutaway block diagram showing modeled conservative effluent-tracer concentration for the injection scenario, Kihei, Hawaii. View is to the northwest; line of section is oriented southwest along the plume axis. Fluid that contains more than 90 percent effluent has been omitted from the diagram, revealing the plume core. The small cubes are fluid-source nodes in the model that correspond to the open interval of the injection well. Injected effluent rises buoyantly, spreads out near the top of the aquifer, and flows to the coast, mixing with surrounding ground water as shown by the colored concentration bands. Figure 26 shows a corresponding map view. 


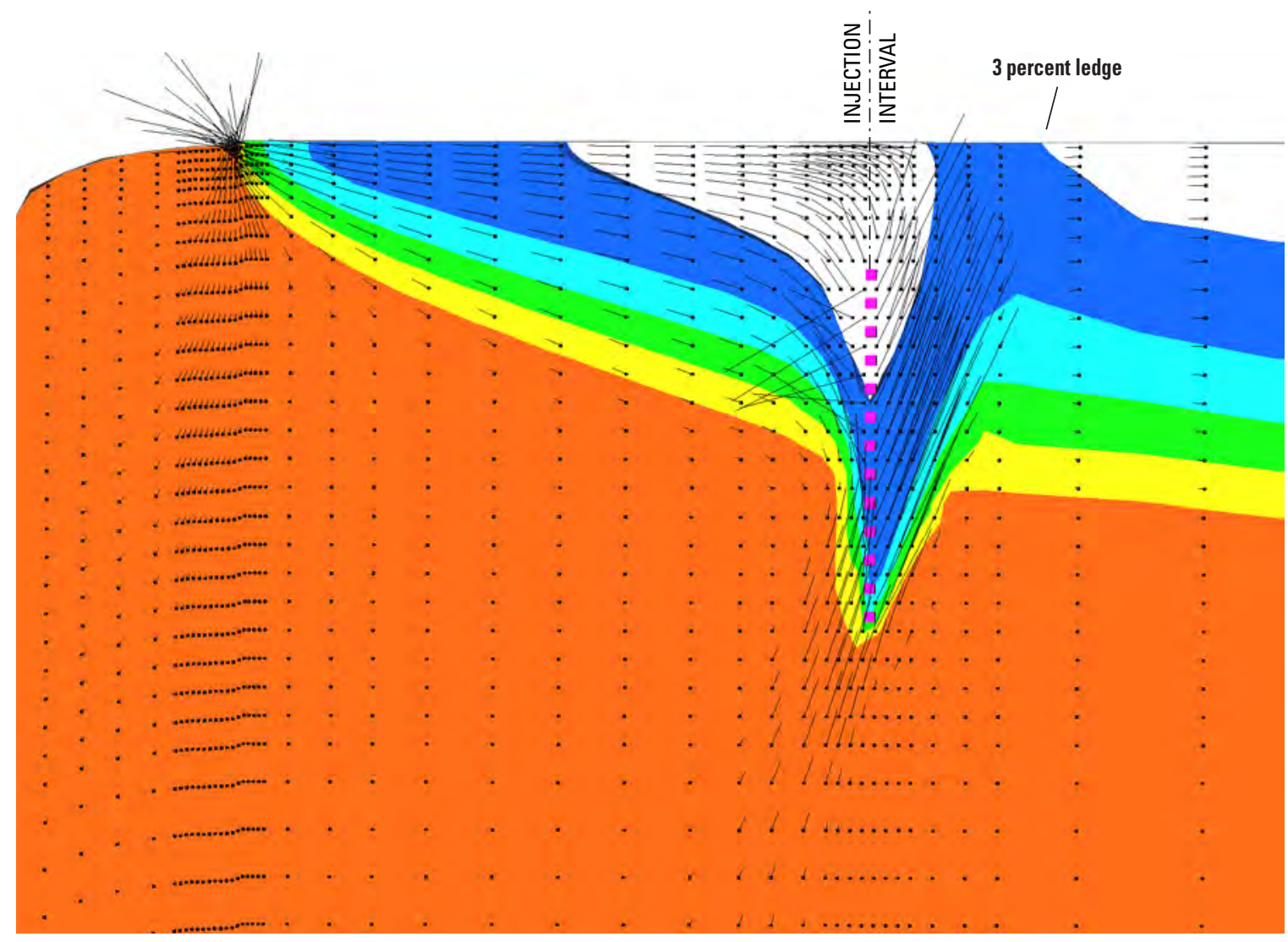

VERTICAL EXAGGERATION 20X

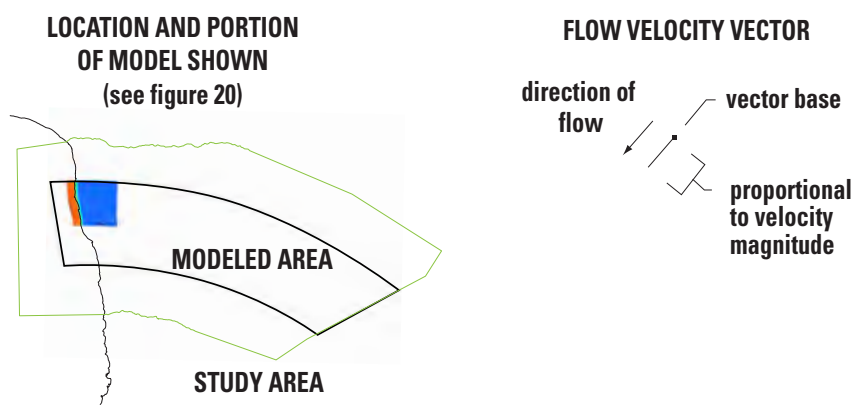

SALINITY, IN PERCENT SEAWATER

Figure 29. Cross section showing modeled salinity and fluid velocity for the injection scenario, Kihei, Hawaii. View is to the north; line of section is oriented east-west along the central axis of the model mesh (fig. 20). Water fresher than 3 percent seawater has been omitted from the section, delineating the fresh core of the injection plume and the freshwater lens inland. The small cubes are fluid-source nodes in the model that correspond to the open interval of the injection well. Low-salinity effluent is injected into the mixing zone and underlying saltwater; it rises buoyantly, spreads out near the top of the aquifer, and flows to the coast, mixing with surrounding ground water. Fluid velocities are greatest (1) near the injection well, as a result of buoyancy and the large injection rate, and (2) near the coast, where flow converges within a progressively thinner mixing zone. Rising effluent entrains saltwater and causes rapid ascent of saltwater beneath the injection interval to resupply the process. Figure 25 shows a corresponding map view. 


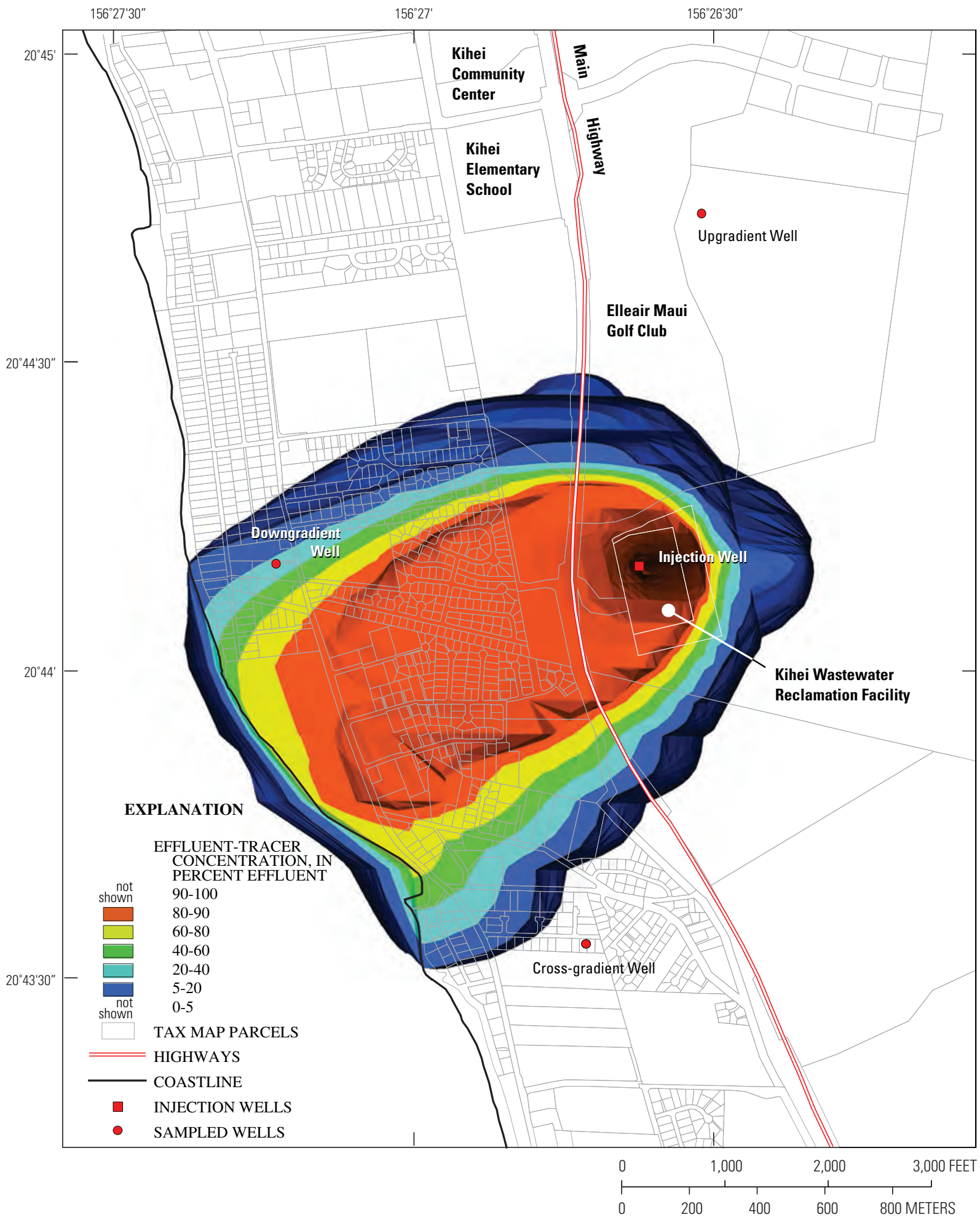

Figure 30. Map showing modeled injection plume at an anisotropy ratio of 200:1, Kihei, Hawaii. Fluid that contains more than 90 percent effluent (or less than 5 percent) has been omitted from the map, revealing the plume core and portraying plume extent to an outer limit of 5 percent effluent. The injection plume encompasses 0.93 miles of coastline and its central axis is aligned southwest, extending through the south part of Kalama Park. 


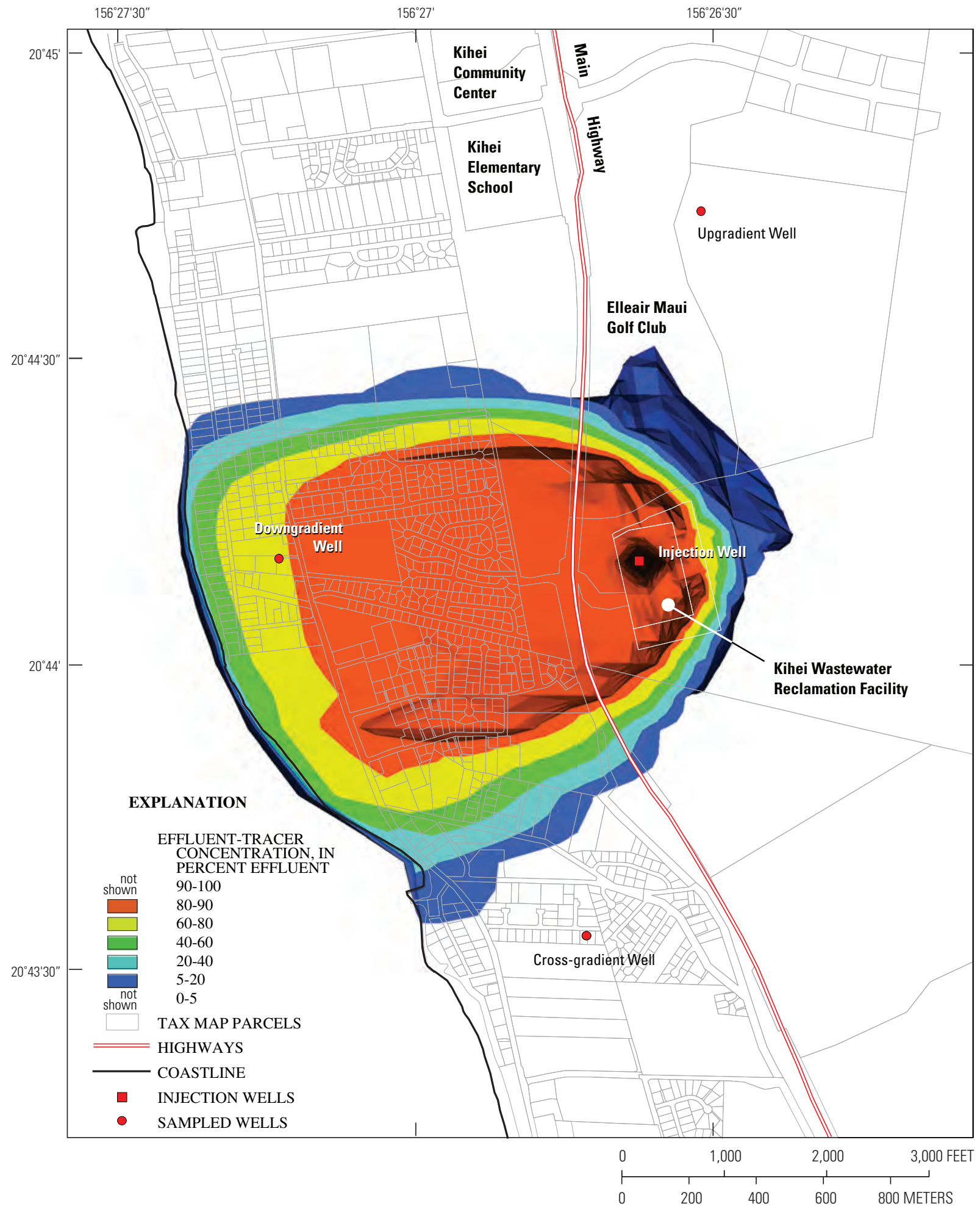

Figure 31. Map showing modeled injection plume at a reduced anisotropy ratio of 20:1, Kihei, Hawaii. Fluid that contains more than 90 percent effluent (or less than 5 percent) has been omitted from the map, revealing the plume core and portraying plume extent to an outer limit of 5 percent effluent. The injection plume encompasses 1.1 miles of coastline and its central axis is aligned west-southwest, extending through the north part of Kalama Park. This plume is wider than the plume at 200:1 anisotropy, and it extends farther north along the coast. 


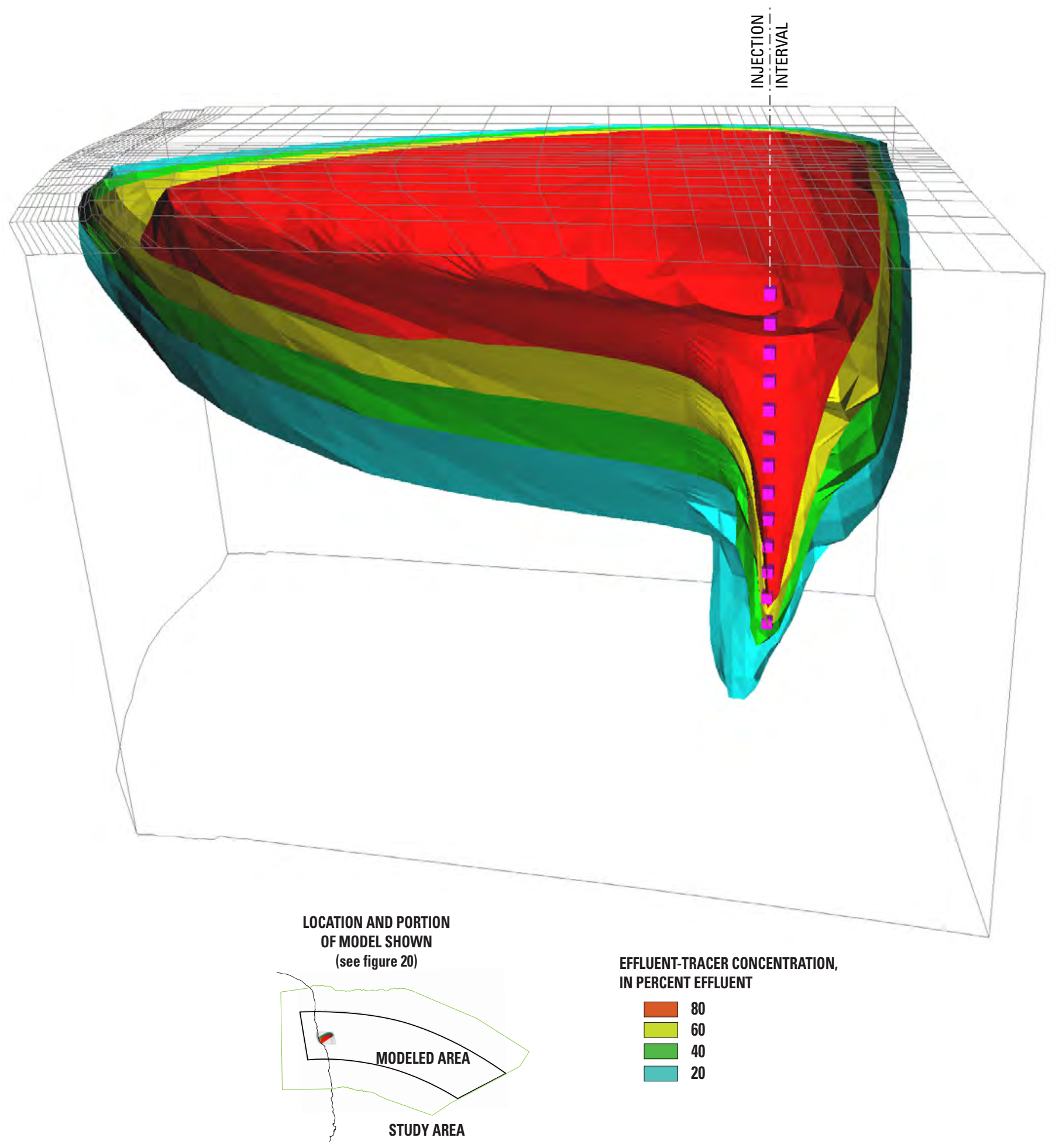

Figure 32. Cutaway block diagram showing modeled injection plume at an anisotropy ratio of 200:1, Kihei, Hawaii. View is to the north; line of section is oriented east-west along the central axis of the model mesh (fig. 20). Colored surfaces of equal effluent concentration are shown at 20, 40,60, and 80 percent effluent. The small cubes are fluid-source nodes in the model that correspond to the open interval of the injection well. 


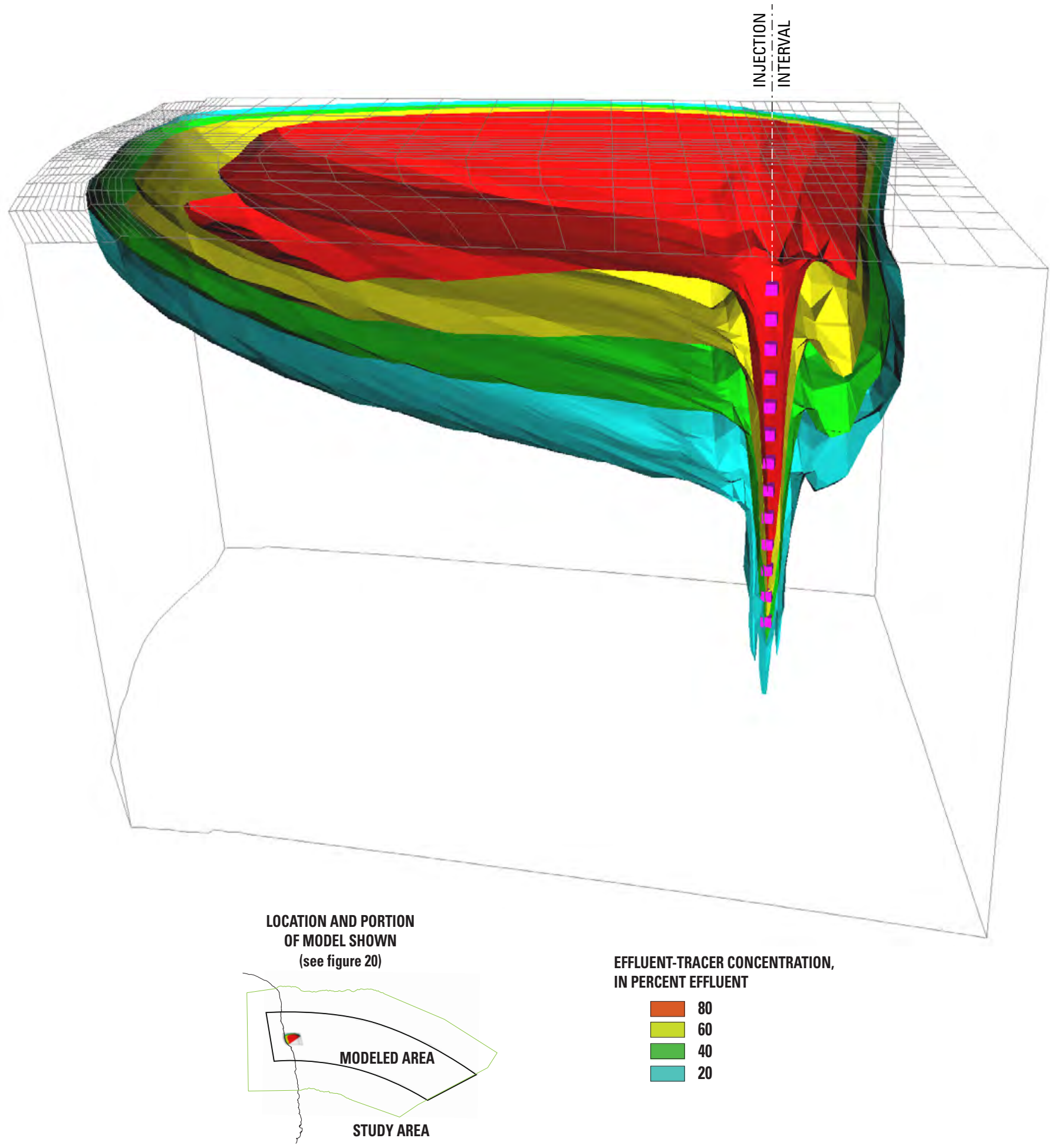

Figure 33. Cutaway block diagram showing modeled injection plume at a reduced anisotropy ratio of 20:1, Kihei, Hawaii. View is to the north; line of section is oriented east-west along the central axis of the model mesh (fig. 20). Colored surfaces of equal effluent concentration are shown at 20,40,60, and 80 percent effluent. The small cubes are fluid-source nodes in the model that correspond to the open interval of the injection well. This plume is thinner and flatter than the plume at 200:1 anisotropy, and it extends farther north along the coast. 
gations might include a beach survey of water chemistry in the likely plume-discharge zone or installation of targeted monitor wells to better define effluent concentrations and to better evaluate the processes that are causing apparent natural attenuation of nutrients within the effluent plume.

\section{Simulated Age of Ground Water}

The age of ground water within the flow system was visualized in a post-processing step similar to that used to display effluent-tracer concentration (Alden Provost and Clifford Voss,
U.S. Geological Survey, written commun., 2005). The final velocity field from the injection scenario was held constant for a single, 100-year-long time step in which concentrations were recomputed. This time, however, initial concentrations were set to zero everywhere and fluid entering the model (whether recharge, seawater, or effluent) was tagged by setting a solute production term (PRODF0) such that simulated concentration equals fluid age. In other words, water "ages" or "grows older" along a flow path and the rescaled concentrations measure the elapsed time since fluid entered at a fluid-source or specifiedpressure boundary. Ground-water ages are displayed by plot-

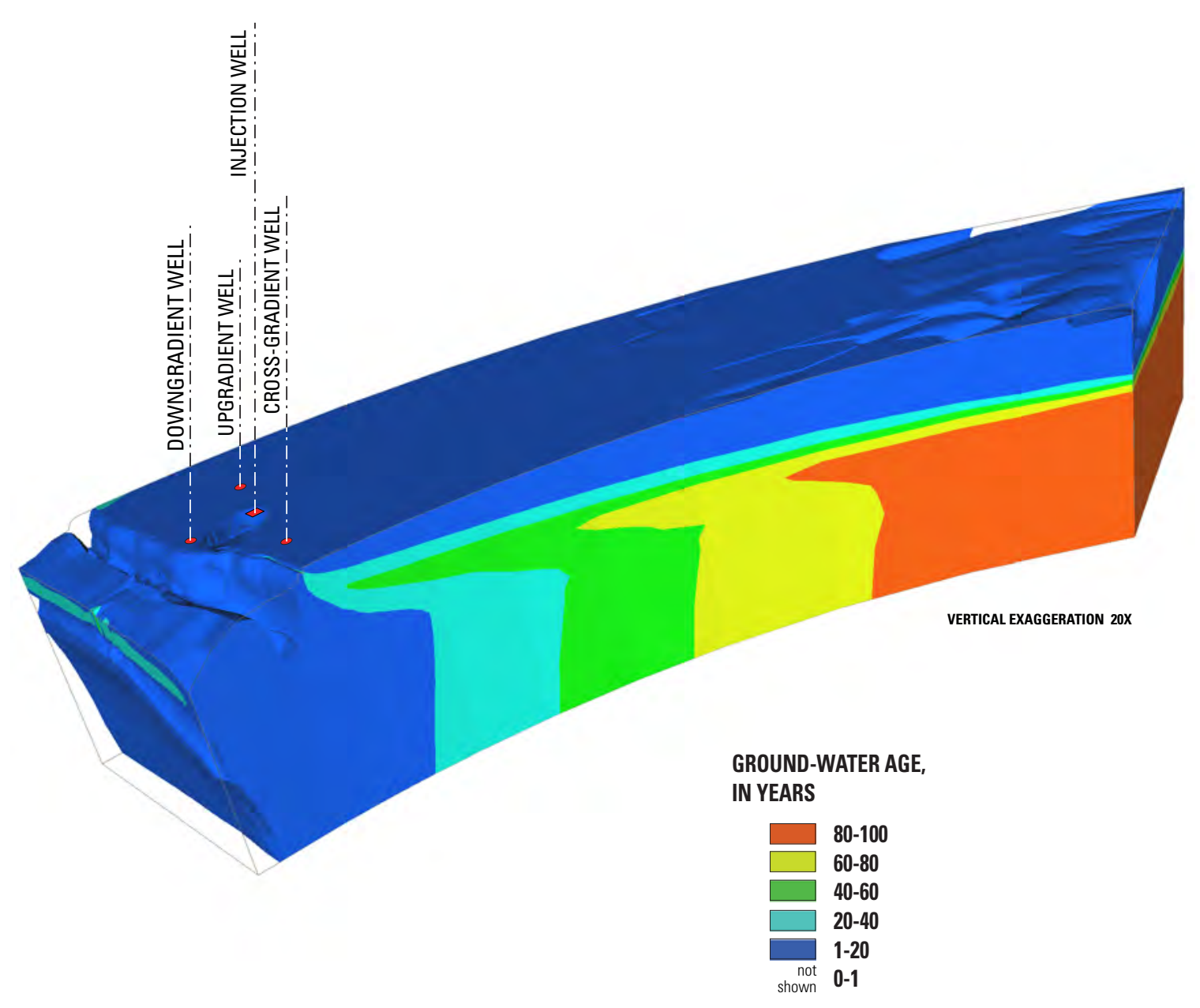

Figure 34. Block diagram showing modeled age of ground water for the injection scenario, Kihei, Hawaii. View is to the north. Each colored band spans 20 years in ground-water age except the blue color band, where water younger than 1 year has been omitted from the diagram, leaving visible depressions that mark the injection plume, young recharge inland, and young saltwater entering along the sea bottom and offshore side of the model. The dominant pattern is a left-to-right aging of saltwater as it flows inland in the lower part of the model. Young recharge at the top of the model grades down into older water in the mixing zone. By comparing this diagram with figure 23, it appears that the entire freshwater lens is younger than 20 years old (blue in this diagram). 
ting simulated concentrations as usual. A 100-year time step was selected-rather than the 30-year time step used for tracer concentration-because velocities in the underlying saltwater flow field are smaller than in the freshwater and effluent flow fields and result in saltwater ages considerably older than 30 years.

Modeled ground-water ages followed patterns anticipated from flow-system concepts (fig. 34). Water is youngest within the freshwater lens (particularly at the water table) and in nearshore parts of the saltwater flow field, where young seawater is entering through the sea bottom and offshore vertical face of the model. The very youngest water less than 1 year old has been stripped from the diagram, leaving a hollow injection plume core, dimples at the top of the freshwater lens farther inland that correspond to young recharge, and a hollow trench and vertical slab offshore that correspond to the youngest saltwater in the system (the aqua band of older water along the offshore vertical face is a suspected computational artifact related to mesh size or position at the model boundary). Dominant patterns in the diagram are the aging of saltwater as it flows inland in the lower part of the model and an upward progression to younger ages in the mixing zone (or to older ages downward). An expected pattern of freshwater aging from mountain to shore is not distinguishable in this diagram because the age scale is governed by very old saltwater, whereas the expected freshwater aging takes place mainly within the youngest blue band (less than 20 years). Coastal ground-water discharge is mostly younger than 20 years according to this diagram, which shows dark blue along nearly all of the shore.

However, the expected shoreward aging in the freshwater flow field is evident in figure 35, which maps simulated ground-water age at the top of the model. The progression from blue inland to yellow at the shore marks a lateral increase in simulated age from about 5 to 20 years. Water younger than 1 year has been stripped off, revealing that much of the plume core consists of effluent less than a year old, as computed by the model. Water discharging along most of the coast has simulated age between 15 and 20 years (yellow), with a small amount of water older than 20 years (red) at the far north. Injection forms a plume of effluent generally 5 years old or younger (blue) in an area that would otherwise be occupied by water about 10 to 20 years old (green and yellow). At the shore, discharge from most of the plume is 5 years or younger, and is as young as 1 year at the plume apex. The blue color offshore is young seawater entering the aquifer along the sea bottom. Apparent older water at the extreme left edge of the model is suspected to be a computational artifact related to mesh size or position at the model boundary. Ages deeper in the flow system are older than those shown here at the very top of the model.

Simulated ages can be compared with sampled ages from CFCs (chlorofluorocarbons) and $\mathrm{SF}_{6}$ (sulfur hexafluoride), atmospheric gas tracers that have known release histories. As seen in figure 35 , simulated ages are about 8,8 , and 12 years at the downgradient, upgradient, and cross-gradient wells, respectively. These compare with $\mathrm{SF}_{6}$ apparent ages of 18, 24, and 25 years and CFC apparent ages about a decade older at 28,34 , and 34 years (table 2). If the sampled ages are reliable, they suggest that the model underestimates ground-water age by factors of 2 to 4 .

This discrepancy between simulated and sampled ages could result from misassignment of model parameters or recharge rates. A good candidate parameter for reconsideration is effective porosity, as there is considerable uncertainty in the 4-percent value derived from Oahu modeling and used for Kihei. Increasing porosity by factors of 2 to 4 would bring better agreement in ages and should require little or no recalibration of hydraulic conductivity. These porosity values are plausible for Hawaiian lava aquifers (Mink, 1977; Hunt, 1996) and would have the added advantage of decreasing pore velocities and allowing transverse dispersivity to be increased closer to values used in Oahu modeling (Delwyn Oki, U.S. Geological Survey, written commun., 2005). Reducing recharge to onehalf or one-quarter its present value also would bring better age agreement but would require recalibration of hydraulic conductivity and dispersivity.

Alternately, it may be the sampled ages that contribute to the age disagreement, at least partly. Both CFCs and $\mathrm{SF}_{6}$ can degrade under anoxic conditions, resulting in apparent ages that are artificially biased older than true water age. However, this typically requires methanogenic conditions, and ground water from the upgradient and cross-gradient wells was highly oxic (table 2), so ages there should not be suspect. The downgradient well is in the anoxic effluent plume, but no methane was detected in the water sample (table 2) and the age disagreement there is no worse than at the other wells. The decade difference between $\mathrm{SF}_{6}$ and $\mathrm{CFC}$ ages likely indicates that the samples contain mixtures of older and younger water, which is expected when open intervals of wells are more than a few feet long.

No attempt was made to recalibrate the model to resolve the discrepancy between simulated and sampled ages. The age discrepancy is an issue that could be revisited by future modeling at Kihei. The existing model calibration suffices for first-order estimates of plume width and behavior, given the uncertainty owing to the various poorly constrained parameters in the model.

\section{Limitations of the Numerical Model}

There are several fundamental types of limitations to the Kihei model, one being spatial detail. For computational reasons, the model mesh strikes a compromise between encompassing a large regional extent and having sufficient detail in areas of interest at the injection well and near the shore. As a result of this compromise, results may be less than fully accurate in some parts of the model. Slight irregularities in simulated salinity were noticed down the center of the model, where mesh spacing is smallest. These likely are computational artifacts related to combined interaction among mesh 


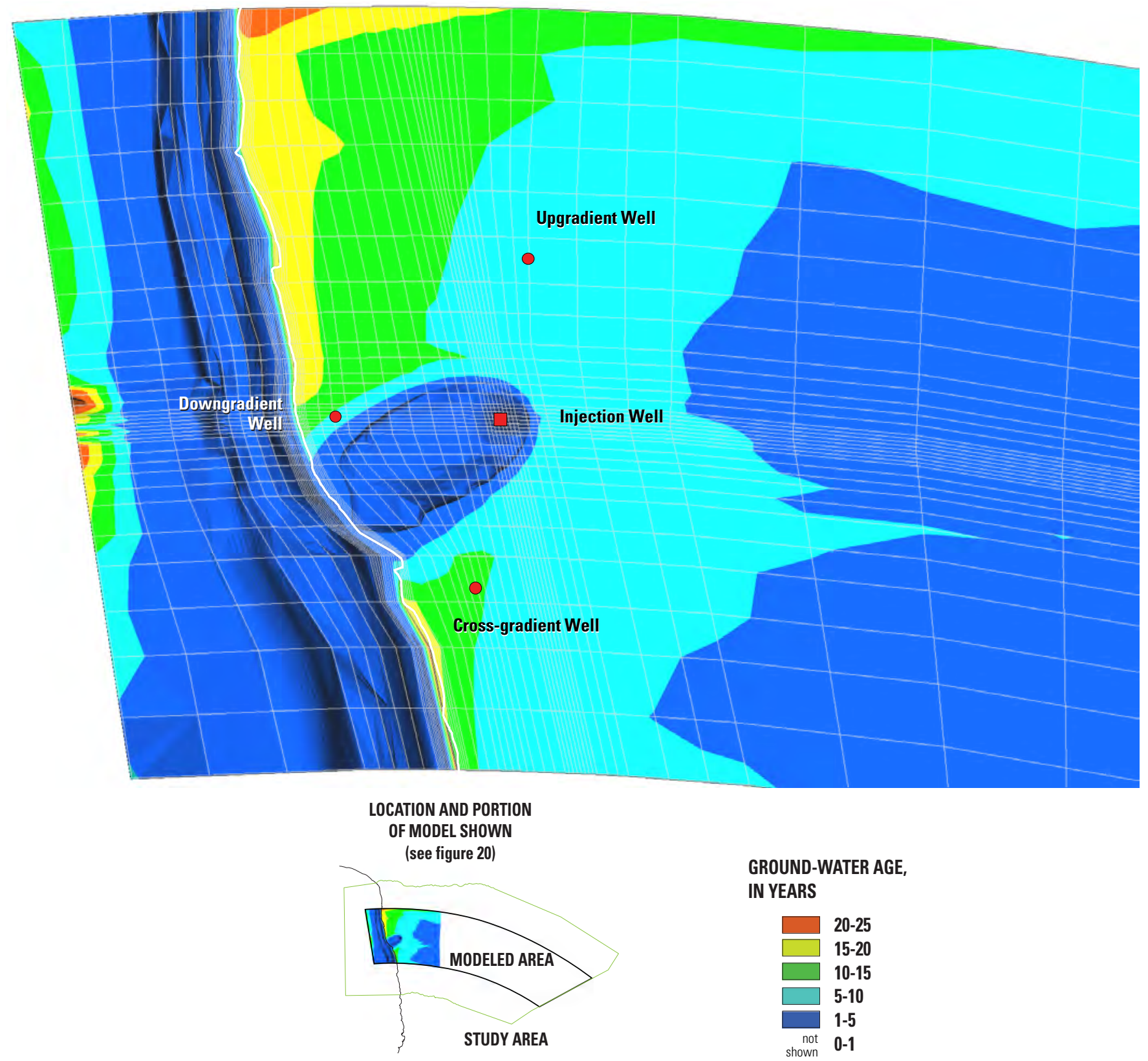

Figure 35. Map showing modeled age of shallow ground water near the shore for the injection scenario, Kihei, Hawaii. Simulated ground-water age increases toward the coast as water ages along flowpaths. Ground water at the top of the model is 15-20 years old along most of the coast, but this pattern is interrupted by the injection plume of younger water as little as 1-5 years old. 
spacing, time step, and parameter values. Considerable mesh refinement and time-step experimentation would be needed to eliminate them, and they did not appear to affect general results in the overall mesh. A smaller subregional model with a finer mesh could be useful, for example to study discharge at the shore in more detail. On the other hand, the model mesh is fairly detailed in the vertical dimension, as well as in plan view near the injection wells and shore.

Another type of limitation has to do with physical features not represented in the model or represented with insufficient detail. For example, confining coastal sediments are expected to influence ground-water discharge, but sediments were not built into the model. Their presence was not required by the fairly simple water-level calibration that was done and, in fact, adding low-permeability sediments would have produced a worse fit to water levels by causing a flatter water table when the water table already is not steep enough in the present calibration. Furthermore, the downgradient well is screened in sediments, not in the volcanic aquifer, and the observed field salinity at that well may depend to an unknown extent on actual sediment properties not represented in the model. Simulation of sediments might have improved agreement between simulated and observed salinity close to shore but would have introduced more fitting parameters and required a more exhaustive calibration effort, trading off effects of sediments with effects of transverse dispersivity in the calibration. In the end, it was decided to forgo a more complex calibration and accept that the model is sufficient for estimating plume size and shape in a regional setting but is not capable of simulating precise flow and salinity details near the shore. Incorporating the effects of confining coastal sediments would be more worthwhile in a detailed subregional model specifically designed to study details of nearshore discharge. Additional field data also would be needed to calibrate hydraulic properties of modeled sediments and to judge model fit to reality near the shore.

A similar type of limitation has to do with processes not represented in the model. In this category the model is fairly complete in that it includes the principal flow, dispersion, and density-dependent processes necessary to realistically simulate (1) the regional, recharge-driven freshwater lens; (2) mixing with saltwater and the resultant circulatory saltwater flow system; (3) injection and buoyant rise of effluent; and (4) displacement and diversion of ambient ground water by the effluent plume. Plume dimensions and behavior have probably been estimated fairly realistically, given overall assumptions. However, tidal fluctuations were not simulated and dispersivities may be somewhat misassigned to reproduce the observed regional salinity distribution when, in fact, tides may be responsible for some of the observed mixing. Thermal effects also were not simulated. Injected effluent is 7 degrees Celsius warmer than ambient ground water at the upgradient well (table 2) and this would tend to further enhance effluent buoyancy.

Nutrient transport and attenuation processes were not simulated, although this is now possible with a new version of SUTRA that simulates multiple chemical solute species (Hughes and Sanford, 2005). The multispecies code could be of use in evaluating reactive processes within the injection plume, for example attenuation of nitrogen by denitrification. However, this would be best accomplished with a more detailed mesh and with more field data to constrain the model (data from more wells, existing or newly drilled, that better define water chemistry and attenuation processes within the plume).

A final set of limitations has to do with uncertainties in boundary conditions, fluxes, and physical properties of the model, many of which were roughly estimated, of unknown accuracy, and without adequate field data for calibration by fitting. The injection rate is sufficiently representative of the last 8 years. Recharge was a best estimate from available literature and should be adequate, although perhaps it could be improved. Porosity of 4 percent was assigned from prior modeling studies on Oahu, although values of 8 to 16 percent are plausible for Hawaiian basalts and would improve agreement between simulated and sampled ground-water ages. Confidence in model calibration could be improved by better field data, such as a consistent dataset for water levels or additional water chemistry and isotope data that would allow fuller field delineation of the injection plume. The side boundaries of the model are perhaps most questionable: whether there is appreciable flow across the north and south boundaries and whether the offshore vertical boundary should be adjusted to regulate the saltwater flow field. Pertinent field data could help resolve these questions, as could more refined modeling of the rest of central and south Maui, which is underway but not yet completed (Stephen Gingerich, U.S. Geological Survey, 2006, oral commun.).

The model could no doubt be improved by additional data or fuller use of existing data. However, the present model is consistent with available data at a basic level, and with prior parameter values used in modeling on Oahu. The formulation and calibration of the model are judged to be adequate for the modest objectives of this study, principally first-order estimation of the shape and extent of the wastewater injection plume under steady-flow conditions.

\section{Summary and Conclusions}

The purpose of this study was to estimate ground-water nutrient fluxes to coastal waters near Kihei, Maui, with particular attention to a presumed large nutrient flux from municipal wastewater injection. Nutrient sources in the area include nonpoint contributions from forested, agricultural, and urban lands; point-source injection of treated wastewater effluent; and nonpoint reapplication of reclaimed wastewater as landscape irrigation. Three approaches were used: (1) sampling of wells and wastewater effluent for nutrients and other constituents; (2) estimation of nutrient fluxes carried by ground water; and (3) simulation of a wastewater plume using 
a three-dimensional numerical model of regional freshwater flow and injection. Very few wells were sampled, limiting the certainty of nutrient-flux estimates and model calibration.

Treated wastewater effluent has a dissolved nitrogen concentration roughly 6 times the background concentration in local ground water and twice the concentration at a downgradient well thought to lie within the effluent plume. Dissolved phosphorus concentration in effluent is 26 times background concentration and 9 times the concentration at the downgradient well. Nitrogen stable-isotope compositions at the downgradient well are roughly consistent with effluent that has undergone denitrification, and this interpretation is supported by low dissolved-oxygen content that would correspond to denitrifying conditions.

A combination of chemicals and isotopes served as water and wastewater tracers. These were used to infer a wastewater component at the downgradient well with high confidence, and this approach should allow wastewater tracing elsewhere at Kihei, whether originating from injection, cesspools, sewer leaks, or landscape irrigation with reclaimed wastewater. Numerous pharmaceuticals and organic wastewater compounds were detected in effluent, but only a few were detected at the downgradient well. Stable isotopes of nitrogen and boron were very good wastewater tracers because domestic waste and laundry detergents impart diagnostic signatures that differ distinctly from local ground-water compositions on isotope plots. Hydrogen and oxygen stable isotopes were good tracers for distinguishing tap water and wastewater from local ground water but not from each other. Imported tap water has the isotopic signature of the area where it originates; this signature persists through use and treatment cycles into wastewater and is distinctly different from ground water recharged locally. Chemical and isotopic approaches used in this study might also succeed in distinguishing an urban fertilizer signature at Kihei, although sampling was not widespread enough to accomplish this in the present study.

Natural ground-water flow through the study area was estimated from a water budget to be $22.6 \mathrm{Mgal} / \mathrm{d}$ along 8 miles of coastline. Another $3.0 \mathrm{Mgal} / \mathrm{d}$ of reclaimed wastewater is injected, equivalent to 13 percent of total natural flow. Background nutrient loads carried by ground water were estimated at $100 \mathrm{~kg} / \mathrm{d}$ of nitrogen and. $5.7 \mathrm{~kg} / \mathrm{d}$ of phosphorus. Injection adds $83 \mathrm{~kg} / \mathrm{d}$ nitrogen and $20 \mathrm{~kg} / \mathrm{d}$ phosphorus to ground water, nearly as much nitrogen and 3.4 times the phosphorus as are in the background load for the entire 73 square-mile study area. Not all the injected nutrient load reaches coastal waters, however, as nutrients apparently are naturally attenuated in the aquifer before ground water discharges to the ocean. Injected nitrogen and phosphorus fluxes are 7 to 30 times greater than background flux per unit coastline when estimated from concentrations in source effluent but fall to 3.5 and 3.4 times background when estimated from lower concentrations in the downgradient well that reflect nutrient attenuation in the effluent plume. Nutrient fluxes at Kihei were mostly within previous ranges estimated at Lahaina, Maui, and on Hawaii Island. Background nitrogen flux was greater at Kihei than at Lahaina, but less than resort and golf-course fluxes on Hawaii Island. Injected nutrient flux at Kihei is about one-third or less than at Lahaina, mainly because the Kihei injection plume is wider; the total mass of injected nutrients is more closely comparable at both locations.

A three-dimensional numerical ground-water model was used to simulate regional freshwater flow and wastewater injection. Because effluent is much fresher than the brackish to saline water into which it is injected, the effluent rises as a buoyant plume and spreads out at the top of the freshwater lens, displacing other ground water flowing from uplands to shore. The simulated injection plume is 0.93 miles $(1.5 \mathrm{~km})$ wide at the coast. Effluent mixes with surrounding water as it flows shoreward, and discharge at the shore is roughly 60 percent effluent in the central core of the plume, according to the model. Simulated ages of ground water at the shore were 5 years or less within the central core of the plume and 15-20 years outside the plume. The model as presently conceived is adequate for first-order estimation of plume size and geometry. Further model refinement would be needed to reproduce low salinities that have been observed at the beach face, as well as sampled $\mathrm{SF}_{6}$ and $\mathrm{CFC}$ ground-water ages that are 2-4 times older than simulated ages. A smaller and more detailed model would be needed to address fine details in the ground-water discharge zone at the shore and for short distances offshore.

Water sampling was localized in the vicinity of the Maui County Kihei injection wells to define the wastewater plume and its chemistry, and very few wells were sampled. One consequence is that nonpoint nutrient contributions from the greater urban landscape were not characterized, including landscape fertilizers (residential, resort, and golf courses) and residential cesspools and septic systems. These urban nutrient sources could be potential subjects for further sampling and evaluation of nutrient loading in the Kihei area. Beach surveys of water quality may better define where nutrient-laden ground water discharges, and some of the geochemical tracers used in this study could be incorporated in such surveys. Targeted monitor wells in the effluent plume would be a good means of verifying the apparent natural attenuation of nutrients observed in this study, and portable well-point sampling of nearshore sediments might determine if additional attenuation occurs between the shore and the downgradient well sampled here. Sampling of beach and ocean-bottom pore waters may help define the nutrient load in ground water just prior to discharge. However, tides and seawater mixing make it difficult to discern representative or average conditions in this nearshore zone. 


\section{References}

Argus Interware, Inc., 1997, User's Guide Argus ONETM, Argus Open Numerical Environments-A GIS modeling system, version 4.0: Jericho, NY, Argus Holdings, Limited, 506 p., last accessed July 28, 2006, at http://www.argusint. com/supportframe.html.

Barber, L.B., Thurman, M.E., Schroeder, M.P., and LeBlanc, D.R., 1988, Long-term fate of organic micropollutants in sewage-contaminated groundwater: Environmental Science and Technology, v. 22, no. 2, p. 205-211.

Barber, L.B., Murphy, S.F., Verplanck, P.L., Sandstrom, M.W., Taylor, H.E., and Furlong, E.T., 2006, Chemical loading into surface water along a hydrological, biogeochemical, and land use gradient - a holistic watershed approach: Environmental Science and Technology, v. 40, no. 2, p. 475-486.

Benitez-Nelson, C.R., 2000, The biogeochemical cycling of phosphorus in marine systems: Earth-Science Reviews, v. 51, p. 109-135.

Boyd, R.A., and Furlong, E.T., 2002, Human-health pharmaceutical compounds in Lake Mead, Nevada and Arizona, and Las Vegas Wash, Nevada, October 2000-August 2001: U.S. Geological Survey Open-File Report 02-385, 18 p.

Burnham, W.L., Larson, S.P., and Cooper, H.H. Jr., 1977, Distribution of injected wastewater in the saline lava aquifer, Wailuku-Kahului Wastewater Treatment Facility, Kahului, Maui, Hawaii: U.S. Geological Survey Open-File Report 77-469, 58 p.

Cahill, J.D., Furlong, E.T., Burkhardt, M.R., Kolpin, Dana. and Anderson, L.G., 2004, Determination of pharmaceutical compounds in surface- and ground-water samples by solidphase extraction and high-performance liquid chromatography-electrospray ionization mass spectrometry: Journal of Chromatography A, v. 1041, no. 1-2, p. 171-180.

Clark, I.D., and Fritz, Peter. 1997, Environmental isotopes in hydrogeology: Boca Raton, FL, CRC Press, 328 p.

Cooper, H.H., Jr., 1959, A hypothesis concerning the dynamic balance of fresh water and salt water in a coastal aquifer: Journal of Geophysical Research, v. 64, no. 4, p. 461-467.

County of Maui, 2004, Kihei wastewater reclamation facility underground injection control (UIC) injection well status report no. 19: County of Maui Wastewater Reclamation Division, $28 \mathrm{p}$.

Dollar, S.J., and Atkinson, M.J., 1992, Effects of nutrient subsidies from groundwater to nearshore marine ecosystems off the island of Hawaii: Estuarine, Coastal and Shelf Science, v. 35 , p. $409-424$.
Dollar, Steven, and Andrews, Christine, 1997, Algal blooms off west Maui-assessing causal linkages between land and the coast ocean: Final Report for National Oceanic and Atmospheric Administration Coastal Ocean Program Office and University of Hawaii Sea Grant College Program, 35 p. plus tables and illustrations.

Drewes, J.E., Heberer Thomas, Rauch Tanja, and Reddersen, Kirsten, 2003, Fate of pharmaceuticals during ground water recharge: Groundwater Monitoring and Remediation, v. 23, no. 3, p. 64-72.

Freeze, R.A., and Cherry, J.A., 1979, Groundwater: Englewood Cliffs, N.J., Prentice-Hall, Inc., 604 p.

Gardner, J.V., Dartnell, P., Mayer, L.A., and Hughes Clarke. J.E., 2000, Bathymetry and selected perspective views of sea floor north and west Maui, Hawaii: USGS Water Resources Investigations Report 00-4046 (2 map sheets).

Garrison, G.H, Glenn, C.R., and McMurtry, G.M., 2003, Measurement of submarine groundwater discharge in Kahana Bay, Oahu, Hawaii: Limnology and Oceanography, v. 48, no. 2, p. 920-928.

Giambelluca, T.W., Nullet, M.A., and Schroeder, T.A., 1986, Rainfall atlas of Hawai'i: State of Hawaii, Department of Land and Natural Resources, Report R76, 267 p.

Gingerich, S.B., and Sherrod, D.R., 2002, Drilling and construction data for the Waiohuli exploratory well (State well 6-4421-01), Island of Maui, Hawaii: U.S. Geological Survey Open-File Report 02-477, 10 p.

Gingerich, S.B., and Voss, C.I., 2005, Three-dimensional variable-density flow simulation of a coastal aquifer in southern Oahu, Hawaii, USA: Hydrogeology Journal, v. 13, no. 2, p. 436-450.

Glassmeyer, S.T., Furlong, E.T., Kolpin, D.W., Cahill, J.D., Zaugg, S.D., Werner, S.L., Meyer, M.T., and Kryak, D.D., 2005, Transport of chemical and microbial compounds from known wastewater discharges: Potential for use as indicators of human fecal contamination: Environmental Science and Technology, v. 39, no. 14, p. 5157-5169.

Hawaii Water Environment Association, undated, The Kihei effluent reuse system, County of Maui: photograph entitled "Extent of the Kihei Effluent Reuse System," last accessed July 28, 2006, at http://www.hwea.org/watreuse/wrkihei. htm.

Heutmaker, D.L, Peterson, F.L., and Wheatcraft, S.W., 1977, A laboratory study of waste injection into a Ghyben-Herzberg groundwater system under dynamic conditions: Technical Report No. 107, Water Resources Research Center, University of Hawaii, Honolulu, 65 p. 
Hsieh, P.A., and Winston, R.B., 2002, User's guide to Model Viewer, a program for three-dimensional visualization of ground-water model results: U.S. Geological Survey OpenFile Report 02-106, 18 p., last accessed July 28, 2006, at http://water.usgs.gov/nrp/gwsoftware/modelviewer/Model Viewer.html.

Hughes, J.D., and Sanford, W.E., 2005, SUTRA-MS a Version of SUTRA Modified to Simulate Heat and Multiple-Solute Transport: U.S. Geological Survey Open-File Report 20041207, 141 p., last accessed July 28, 2006, at http://water. usgs.gov/nrp/gwsoftware/SutraMS/SutraMS.html.

Hunt, C.D. Jr., 1996, Geohydrology of the island of Oahu, Hawaii: U.S. Geological Survey Professional Paper 1412-B, $54 \mathrm{p}$.

Jordan, M.J., Nadelhoffer, K.J., and Fry, Brian, 1997, Nitrogen cycling in forest and grass ecosystems irrigated with ${ }^{15} \mathrm{~N}$ enriched wastewater: Ecological Applications, v. 7, no. 3, p. 864-881.

Kendall, C., and McDonnell, J.J., eds., 1998, Isotope Tracers in Catchment Hydrology: Amsterdam, Elsevier Science, $839 \mathrm{p}$.

Kolpin, D.W., Furlong, E.T., Meyer, M.T., Thurman, E.M., Zaugg, S.D., Barber, L.B., and Buxton, H.T., 2002, Pharmaceuticals, hormones, and other organic wastewater contaminants in U.S. streams, 1999-2000-A national reconnaissance: Environmental Science and Technology, v. 36, no. 6, p. 1202-1211.

Langenheim, V.A.M., and Clague, D.A., 1987, The HawaiianEmperor volcanic chain, part II, stratigraphic framework of volcanic rocks of the Hawaiian islands, chap. 1, in Decker, R.W., Wright, T.L., and Stauffer, P.H., eds., Volcanism in Hawaii: U.S. Geological Survey Professional Paper 1350, v. 1, p. 55-84.

Meyer, William, and Presley, T.K., 2001, The Response of the Iao Aquifer to ground-water development, rainfall, and land-use practices between 1940 and 1998, Island of Maui, Hawaii: U.S. Geological Survey Water-Resources Investigations Report 00-4223, 60 p.

Mink, J.F., 1977, Handbook-index of Hawaii groundwater resources data, vol. 1: University of Hawaii Water Resources Research Center Technical Report No. 113, Honolulu, HI, 119 p.

National Geophysical Data Center, 2004, NGDC Coastal Relief Model: National Oceanic and Atmospheric Administration web page, Carla J. Moore, webmaster, last accessed July 28, 2006, at http://www.ngdc.noaa.gov/mgg/coastal/ coastal.html.
Provost, A.M., 2004, SutraSuite online user reference: U.S. Geological Survey, Reston, VA, last accessed July 28, 2006, at http://water.usgs.gov/nrp/gwsoftware/sour/index.htm.

Rougerie, Francis, and Wauthy, Bruno, 1993, The endoupwelling concept-From geothermal convection to reef construction: Coral Reefs, v. 12, p. 19-30.

Ryan, M.P., 1996, Compartmentalized hydrothermal convection systems (abs.): Eos, Transactions, American Geophysical Union, in AGU 1996 fall meeting. v. 77, no. 46, Supplement, November 12, 1996, p. 756.

Scholl, M.A., Gingerich, S.B., and Tribble, G.W., 2002, The influence of microclimates and fog on stable isotope signatures used in interpretation of regional hydrology-East Maui, Hawaii: Journal of Hydrology, v. 264, p. 170-184.

Scholl, M.A., Ingebritsen, S.E., Janik, C.J., and Kauahikaua, J.P., 1995, An isotope hydrology study of the Kilauea Volcano area, Hawaii: U.S. Geological Survey Water Resources Investigations Report 95-4213, 44 p.

Sedlak, D.L., and Pehlivanoglu, Elif, 2004, The speciation and reactivity of wastewater-derived organic nitrogen: University of California Water Resources Research Center Technical Completion Report W-972, Berkeley, 26 p.

Seitzinger, S.P., Sanders, R.W, and Styles, Renee, 2002, Bioavailability of DON from natural and anthropogenic sources to estuarine plankton: Limnology and Oceanography, v. 47, no. 2, p. 353-366.

Shade, P.J., 1999, Water budget of east Maui, Hawaii: U.S. Geological Survey Water-Resources Investigations Report 98-4159, 36 p.

Soicher, A.J., and Peterson, F.L., 1996, Assessing terrestrial nutrient and sediment discharge to the coastal waters of west Maui, Hawaii: Final Project Report for National Oceanic and Atmospheric Administration Coastal Ocean Program Office, 98 p.

Soicher, A.J., and Peterson, F.L., 1997, Terrestrial nutrient and sediment fluxes to the coastal waters of west Maui, Hawaii: Pacific Science, v. 51, no. 3, p. 221-232.

Souza, W.R., and Voss, C.I., 1987, Analysis of an anisotropic coastal aquifer system using variable-density flow and solute transport simulation: Journal of Hydrology, v. 92, p. 17-41.

State of Hawaii, 1996, Hawaii's coastal nonpoint pollution control program, management plan volume 1: Hawaii Coastal Zone Management Program, Office of State Planning, last accessed July 28, 2006, at http://www.hawaii. gov/dbedt/czm/czm_initiatives/6217.html. 
State of Hawaii, 2002, Hawaii Commission on Water Resources Management unpublished digital database containing records of drilled wells.

State of Hawaii, 2004a, State land use districts-2004: State of Hawaii Land Use Commission, last accessed July 28, 2006, at http://www.state.hi.us/dbedt/gis/slud04.htm.

State of Hawaii, 2004b, State of Hawaii Data Book: State of Hawaii Department of Business, Economic Development \& Tourism, last accessed July 28, 2006, at http://www.hawaii. gov/dbedt/info/economic/databook/.

Stearns, H.T., and Macdonald, G.A., 1942, Geology and ground-water resources of the island of Maui, Hawaii: Hawaii (Territory) Division of Hydrography Bulletin 7, $334 \mathrm{p}$.

Stewart, R.H., 2005, Introduction to Physical Oceanography: online textbook, Texas A\&M University, last accessed July 28, 2006, at http://oceanworld.tamu.edu/home/course_book. htm.

Takasaki, K.J., 1972, The water resources of central Maui: U.S. Geological Survey and State of Hawaii Department of Land and Natural Resources preliminary report, Circular C62, $59 \mathrm{p}$.

Takasaki, K.J., and Mink, J.F., 1985, Evaluation of major dikeimpounded ground-water reservoirs, island of Oahu: U.S. Geological Survey Water-Supply Paper 2217, 77 p.

Tetra Tech, Inc., 1994, Effluent fate study_Lahaina wastewater reclamation facility: Prepared for U.S. Environmental Protection Agency Region 9, 73 p.

University of Hawaii, undated, Hawaii Coral Reef Initiative Research Program: last accessed July 28, 2006, at http:// www.hawaii.edu/ssri/hcri/index.htm.

U.S. Geological Survey, variously dated, National field manual for the collection of water-quality data: U.S. Geological Survey Techniques of Water-Resources Investigations, book 9, chaps. A1-A9, last accessed July 28, 2006, at http://pubs. water.usgs.gov/twri9A.

Vengosh, Avner, Heumann, K.G., Juraske, S., and Kasher, R., 1994, Boron isotope application for tracing sources of contamination in groundwater: Environmental Science and Technology, v.28, no. 11, p. 1968-1974.
Verstraeten, I.M., Fetterman, G.S., Meyer, M.T., Bullen, Thomas., and Sebree, S.K., 2005, Use of tracers and isotopes to evaluate vulnerability of water in domestic wells to septic waste: Ground Water Monitoring and Remediation, v. 25 , no. 2, p. 107-117.

Voss, C.I., and Provost, A.M., 2002, SUTRA, A model for saturated-unsaturated variable-density ground-water flow with solute or energy transport: U.S. Geological Survey Water-Resources Investigations Report 02-4231, 250 p., last accessed July 28, 2006, at http://water.usgs.gov/nrp/gwsoft ware/sutra/sutra.html.

West Maui Watershed Management Advisory Committee, 1997, West Maui watershed owner's manual, Maui, Hawaii, $104 \mathrm{p}$.

West Maui Watershed Management Project, 1996, Algal blooms-Progress report on scientific research: West Maui Watershed Algal Bloom Task Force, Maui, Hawaii, 64 p.

Widory, David, Petelet-Giraud, Emmanuelle, Negrel, Philippe, and Ladouche, Bernard, 2005, Tracking the source of nitrate in groundwater using coupled nitrogen and boron isotopes-A synthesis: Environmental Science and Technology, v. 39, no. 2, p. 539-548.

Winston, R.B., 2000, Graphical User Interface for MODFLOW, Version 4: U.S. Geological Survey Open-File Report 00-315, 27 p., last accessed July 28, 2006, at http:// water.usgs.gov/nrp/gwsoftware/GW_Chart/GW_Chart.html.

Winston, R.B., and Voss, C.I., 2004, SutraGUI-A graphical user interface for SUTRA, a model for ground-water flow with solute or energy transport: U.S. Geological Survey Open-File Report 03-285, 114 p., last accessed July 28, 2006, at http://water.usgs.gov/nrp/gwsoftware/sutra-gui/ sutra-gui.html.

Zaugg, S.D., Smith, S.G., Schroeder, M.P., Barber, L.B., and Burkhardt, M.R., 2002, Methods of analysis by the U.S. Geological Survey National Water Quality LaboratoryDetermination of wastewater compounds by polystyrenedivinylbenzene solid-phase extraction and capillary-column gas chromatography/mass spectrometry: U.S. Geological Survey Water-Resources Investigations Report 01-4186, $37 \mathrm{p}$. 


